University of Louisville

ThinkIR: The University of Louisville's Institutional Repository

Electronic Theses and Dissertations

$11-1943$

\title{
A history of the Council of Social Agencies of Louisville, Kentucky.
}

Mary Trueheart Williamson

University of Louisville

Follow this and additional works at: https://ir.library.louisville.edu/etd

Part of the Social Welfare Commons

\section{Recommended Citation}

Williamson, Mary Trueheart, "A history of the Council of Social Agencies of Louisville, Kentucky." (1943). Electronic Theses and Dissertations. Paper 2189.

https://doi.org/10.18297/etd/2189

This Master's Thesis is brought to you for free and open access by ThinkIR: The University of Louisville's Institutional Repository. It has been accepted for inclusion in Electronic Theses and Dissertations by an authorized administrator of ThinkIR: The University of Louisville's Institutional Repository. This title appears here courtesy of the author, who has retained all other copyrights. For more information, please contact thinkir@louisville.edu. 
UNIVERSTTY OF LOUISVILLE

A HISTORY OF THE COUNCIL OF SOCIAL AGENCIES OF LOUISVILLE, KENTUCKY

\author{
A Dissertation \\ Submitted to the Faculty \\ Of the Graduate School of the University of Louisville \\ In Partial Fulfillment of the \\ Requirements for the Degree \\ Of Master of Science in Social Administration
}

Graduate Division of Social Administration

By

Mary Trueheart W11liams on

1943 
NAME OF STUDENT: Mary Trueheart Williamson

TITLE OF THESIS: A History of the Council of Social Agencles of Loulsville, Kentucky

APPROVED BY READING COMEITTEE COMPOSED OF THE FOLLOWING WEMBERS :

John J. Cronin

Robert I. Kutak

Annie Louise Pruitt

NAME OF DIRECTOR: John J. Cronin

DATE: November 10,1943 
Chapter

I. A COUNCIL OF SOCIAL AGENCIES . . . . . . . 7

II. FIRST SIEPS TOWARD COORDINAIED SOCIAL PLANNING IN LOUISVILLE--1884-1925 . . . . . . . . 26

III. THE ORGANIZATION OF THE COMMUNTTY CHEST AND ITS SOCIAI PLANNING PROGRAM, 1924-1927 • . . 43

IV. ACTIVITIES OF THE RECREATION AND FAMIIY AND CHILD WEIFARE COUNCIL . . . . . . . . . . 64

V. THE FAMILY AND CHILD FELFARE COUNCIL AND THE RECREATION COUNCIL, 1928-1934 •. •. . . . 79

VI. THE COUNCIL OF SOCIAL AGENCIES, 1935-1939 • 114 VII. THE COUNCII OF SOCIAL AGENCIES, 1940-1943 • 143 CONCLUSIONS ... . . . . . . . . . . . . . . 177 BIBIIOGRAPHY . . . . . . . . . . . . . . 184 APPENDIX . . . . . . . . . . . . . . . . 188 
A HISTORY OF THE COUNCIL OF SOCIAL AGENCIES

OF LOUISVILLE, KENTUCKY 
INTRODUCTION 


\section{INTRODUCTION}

Community social planning has recently received the spotlight of attention under the impacts of war and its related demands for a united nation and community. But to those who have had a more intimete contact with the fleld of social work this is not a new development. For more than twenty years there hes be $\in \mathrm{n}$ in urban areas a steady growth of organizations known as councils of social agencies, welfare councils, or community councils whose job it has been to coordinate and plan the social welfare prograns for the comnuties of which they are a part.

As in other cities, the movement toward a coordinated cominunity program of social planning has also been growing and developing in Louisville, Kentucky. since there is no available history compiled of this development of the Louisville Council of Social Agencles, such a study is of value. In order to achieve the very objectives which a council of soclal agencies sets, it is necessary to have a complete understanding of the component parts of the social services of the comunity. lhrough such a study one not only gains a deeper understanding of the Council itself as one of these parts, but, because of its very nature, one also gets a clesrer 
picture of how the community has gone about meeting its social problems. The importance of this fact is emphasized, for no future program can be put into effect without the full backing of the community. What applies in casework with a client applies also to a community. One enters the situation at a level which is acceptable by the community as a whole. The degree of cooperation between the agencies that compose the council is also apparent from such a study.

The recorded minutes of the annual meetings, of the regular meetings, and of the committee meetings of the Council of Social Agencies shall be the chief sources of information about the specific developinent and work of the Louisville Council. Where gaps in informetion heve existed and where interpretation is necessary we have turned to personal interviews with Miss Mary $\mathbb{B}_{\text {. Stotsen- }}$ burg, Executive Secretary of the Community Chest; Mrs. Louise R. Wood, Executive Secretary of the Council of Social agencies; and to lay persons in the community who have had an ective part in the work of the Council. Fapers given at National Conferences of Social Hork and publications issued by Community Chests ana Councils, Incorporated, will be used to give an understanding of the Eeneral picture of the Council development. In addition, 
other publications on community organization and social administration will be used. Newspaper files were also consulted.

In making this study certain limitations were faced, especially with regard to the Council's early development, for the recording of actions and procedures was meager. It should also be mentioned that often lay people served as recorders and although the minutes were sparse in many instances, they are of value in that they show what the laymen felt was important at the time. Newspaper sources may not be reliable since they tend to emphasize the sensational aspects of the news. Thus a truly scientific approach can be reached only in so far as interpretation is concerned. The whole picture will be given as nearly as posstble, and whatever conclusions are arived at will be on this basis.

Since it has been found that the development of the Council falls into natural divisions, the historical approach has been used.

First, the early sporadic attempts at organization that had similarity to what became eventually the Council of Social Agencles will be discussed. These first steps go back as for as the Charity Organization Society and finaliy evolve into the formation of the Community Council. 
After a short interim, the Health Council, The Recreation Council, and the case work Council were organized. In 1924, the Farnily and Child fielfare Council and the Fecreation council were formed. The pamily and Child velfere council and the Recreation Council carried on their work until 1935 when they were combined under the name of the council of social Agencies. Another change took place in the council in 1939 when it was reorganized on a three divisional basis. From 1939 unti.l June 1943, the work of the Council was affected greatly by the impacts of the rar and its problems. Inis brought a now communty awakening to the need for social planning, and as a result a Civilian Deferse Courcil was organized. How the velfere Division of the Civilian Defense Council vas integrated with the council of Social Agencies was an interesting procedure.

These questions are suggested for consideration as a guide to this study: What is a council of social agencles? How has it evolved? Who makes up the membership? To what extent are the lay members representative of the larger community? What is its relation to the comiunity chest? How dependent is the council on the control of the chest? What is its relation to the national orgarization? What kind of and how much social action can the council Indulge in? Is an adoitional organization necessary to provide more alrect social action? What is the relation of the 
Social Service Exchange and the Volunteer's Bureau to the Council of Social Agencies? How is the Health Council releted to the Council of Social Agencies? Does cooperative planning exist between the two organizations? With which is the Council of Social Agencies more concerned--agency problems or comiunity social problems? This study will endeavor to answer these questions. 
CHAPTER I

A COUNCIL OF SOCIAL AGENCIES 
A COUNCIL OF SOCIAL AGENCIES

The council of social agencies is an instrument of cooperative administration. Through it the citizens and social agencies, cooperatively, may study the needs of their communities and plan for an adequate and integrated program of service. ${ }^{1}$

A council of social agencies is more than a mere organization of agencies interested in social work... it is itself a service agency for the community, helping to select, reject, and inftiate community projects.2

These two statements serve as brief definitions of a council of social agencles, and they will be used as a spring board to consider in more detail the general topic of councils of social agencles. Both statements emphasize the cooperative nature of councils of social agencies. Why are such organizations for cooperation necessary, and how have they evolved?

In studying the history of this development we find that communty organization has been contemporaneous with the evolution of social work itself. Since other

$1_{T}$. L. Swander, "Effective Organization of Social Eorces in Cities Under 500,000 Population" (Paper read at the National Conference of Social Work, Atlantic City, June 3,1941 ).

$2_{\text {Edward H. Kavinoky, "Presidential kddress" (Speech }}$ made at the Annual. Meeting of the Niagara Falls Council of Social Agencies, Buffalo, October 23, 1940). 
1

theses and numerous books have dealt with the history of social work from the time of the English Poor Law, we shall not duplicate those details here. It is recalled that in the early days of social work the moral objectives were predominant and that there appeared numerous agencies competing to serve the poor. The consequence was confusion and indistinctness which resulted in what Mr. David Liggett terms "overlook and overlap." In 1869 in England and in 1877 in the United 3

States, charity organization societies came into being, primarily to organize resources for clients more ef ectively. Mr. Arthur Fink in his book, The Field of Social Nork, points out, that in the beginning, the charity organization movement was performing essentially a community organization job, working with already existing agencies and not attempting direct service to clients.

${ }^{1}$ See Pierce Atwater, Problems of Administration in Social Hork, (Minneapolis:" University of Minnesota Press, 1940), pp. 182-201. Mildred E. Bateman, "Lay Participation in the Privete Family Agency", (Unpublished Master's Thesis, Graduate Division of Social Administration, University of Louisville, 1941). Arthur E. Fink, The Field of Soclal Tork (New York Henry Holt \& Co., 1942), pp. 445-450.

${ }^{2}$ David Liggett, Can Councils Click? (New York: Community Chests and Councils, Inc., 194I), p. 3.

${ }^{3}$ Bateman, op. cit. , pp. 6-8.

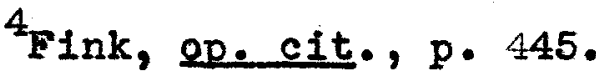


In addition, the charity organization society undertook to bring about certain socially desirable changes such as better housing and improved health standards.

When the function of the charity organization society began to shift to giving direct service to clients, there still remained much of the earlier community organization work to be done. The next step to meet the confusion and duplication of services was the formal organization of councils of social agencies. Milwakee and Pittsburgh are generally credited with the establishment of the first 1

councils of social agencies. The date was 1909, and it is interesting to note that they antedated the first effort in modern federated financing by four years.

The first world war gave a decided impetus to plans for federated financing of the social work in private agencies that soon outstripped councll expansion. In succeeding years the number of councils has increased steadily. Arlien Johnson makes this statement:

The cooperative activities involved in wartime services and the nationwide campaigns $f$ or overseas social service programs developed local community consciousness. In such soll the private social agencies began to feel a new mutualism. The

${ }^{1}$ Community Chests and Councils, Inc., What Councils of Soctal Agencies Do, p. 1 . 
council of social agencies and the community chest afterward became the accepted instrumentalities for central planning and joint financing.

\section{Structure}

The traditional form of organization of a council of socicl agencies provides a delegate body composed largely of representatives, one lay and one professional, from the public and private social, health, and related agencies of the community. Councils usually include in their membership certain individuals who are designated as delegates at large. Agency membership in the council is customarily designated in terms of governing board, staff, and objectives. Almost all councils are inclusive rather than exclusive and are composed of member agencies of the community chest, private social agencies not participating in the chest, and public departments that meet the definition of "social agency." The individual members are selected because of their comunity interest or because they represent certain specified interests such as labor unions or the League of Women Voters. Selection is usually made by the council but some organizations do appoint delegates. Arlien Johnson questions whether this

\section{IArlien Johnson, "Local Social Planning," Survey} Mid-Monthly, LXXVI, No. 10, (October, 1940), 29 I. 
representation is not on an individual rather than an 1 arganization basis.

It is recognized that there is a place for both public and private agencles as partners in the job of serving human beings. The job is to respect, understand, and define the area of service of each agency in order that all persons in need might be served in the most efficlent manner. This raises the question of how great a part the public agencies play in the work of the council of social agencies. If the council is to serve its purpose the work of the public agencies should certainly not be minimized. Miss Johnson feels that it is a great weakness in community planning for the public agency that spends a moch larger amount of money than the private agencles to have only two delegates to the council.

In order to carry out its program, most councils are organized into subordinate groups or sections according to functional flelds of agency activity. Most frequently these are designated family, child welfere, health, and group work divisions. In addition special committees are appointed as the need arises to study specific problems. The individual divisions are usually headed by a lay chalr-

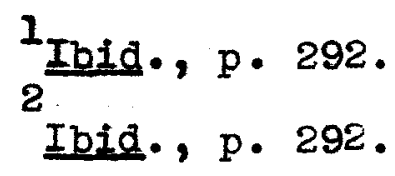


man and most of the responsibility for the work of the division is assumed by a steering comittee or planning conmittee composed of both lay and professional people. It is readily seen that there is a full time job for someone to organize the general work of the entire council program and to view it as an integrated whole. Thus, in those councils that have been established on a solid financial basis, we find a small executive staff is employed to serve the delegate body and its special committees. Often the time of the executive secretary is divided between serving the council and the chest when the two are closely related. It would seem that if the councll is to do a good job, its work would take up all of the executive's time. There is a difference in the type of person required by a chest and the type required by a council, and it would take a most outstanding person who would be able to fill both jobs at the same time.

The relationship of the council of social agencies and the community chest has been mentioned briefly. In recent years this subject has become a focal point of discussion for those in the field of work. It is found that sometimes the council of soctal agenctes was organized at the instigation of the community chest; in other cases the councils of social agencles have been created 
independently. In more recent years in non-chest cities, the councils of social agencies have been known to organize community chests.

Where both chest and council exist, close integration between them is the general rule. This is usually accomplished by an interlocking staff and directorate. Even where councils are continued as independent bodies, they are generally dependent upon the community chest for their financial support.

Mr. Atwater presents quite clearly the main tenets of the two points of view of the proper relationship of council and chest.

....As the importance of public agencies and departments becomes greater, there is some reason to believe that the independent council can serve all groups of agencies better. This observation is by no means conclusive, but the issue does take on importance where the same staff serve both councll and chest leadership. Planning work necessarily stops for several months while council executives labor with the fund raising problem. 1

Mr. Atwater continues by discussing the unifled operation of chest and council.

Since the war (World War I) money raising has been of basic importance in developing and exploiting the field of private social work. ... To obtain good results in chest campaigns it was necessary to have an efficient leadership... At the same time qualities for leadership in social planning were just as urgent

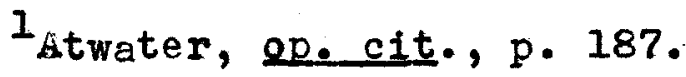


in the councils... The scarcity of leadership combined with its high cost led to the conclusion that these two functions could be combined. As this idea took root, it also became clear that it was difficult to differentiate planning procedures from financial controls... Certainly the consolidation of chest and council provided a basis of easier action, eliminated many elements of conflict, and made possible quicker results because the same board of directors controlled all three functions of central 1 financing, central planning, and central budgeting.

There can be no definite criteria set down as to the best method to follow. The form that a council of social agencies should take should be that which best serves the community of which it is a part. It should be remembered that as it is ideally set up the council is community-wide, and therefore, it mast be financed on a community-wide basis and seved by a staff that is equally responsible to all comrunity agencies.

\section{Rurpose and objectives}

The purpose of a council, states Community Chests and Councils, Inc., is "... to bring about improvements in the quality and adequacy of the social and health services of the community and better to relate these services to the community's needs." Social agencies have come more and more to realize that the serving of

${ }^{1}$ IbId., pp. 187-188.

${ }^{2}$ What Councils of Social Agencies Do, (New York: Community Chests and Councils, Inc., 1939), p. 2. 
the public is much more than a single agency problem. It is not sufficient for one agency to evaluate its own program and to define for itself its purpose, function, and area of operation. Ligr. Liggett calls what is needed an "orchestration of effort."

This orchestration of effort has to do with sharing the financial resources of the community, tax and voluntary, and it has to do with research and social planning to the end that the gradual elimination of overlook and overlap, with the ald of fact-finding, are accepted as the joint program responsibilities of sociki agencies working through and with the council of social agenctes.2

This is a new era as far as social work is concerned, an era in which the re must be coordination and cooperation. Social distance has tended to increase in American comunities, and the council of social agencies can be a means toward lessening social distance.

Councils of social agencies serve as organizations equipped to make dispassionate, impartial, and searching studies; and to interpret them to the community. They serve the changing needs in social welfare; they are agencies for cooperative service and showd engage in activities of a cooperative nature in order to allow agencies to plan together. Councils must not do those things that the

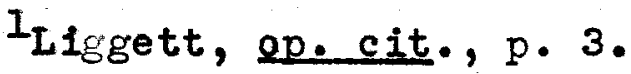
2 Ibid.
} 
agencies can handle individually, but they must confine their activities to those that are comunal in nature.

What is the philosophy underlying the purposes and objectives of the council? The council ideally conforms to the principles of democracy calling for a belief in the integrity and mutual interest of the various component agencies. It accepts the democratic process as the practical one to achieve its ends. Participation is on a voluntary basis. The spirit of the council does not conform with the process of arriving at agreements secret1y. Al important decisions should be subject to analysis and discussion by the delegates. No attempt should be made to coerce a minority. Too often agencies want planning for others but not for themselves. The nature of the council is non-authoritative, and no decisions can be enforced except insofar as there is mutual understand ing that group decisions will be honored.

The realization that there is inter-dependency between agencies and that agencies are only a means in themselves constitutes another aspect of the underlying philosophy. The council is client minded and thus realizes that sometimes its function implies the necessity for changing organizational structure as the needs of people are changed by new forms social and economic 
organization and development. As the council has obligations to its member agencies, so they have obligations to ft. In order to achieve its purpose and objectives knowledge is a basic principle. The council must have a thorough knowledge of the set up of local organizations. It should know the quality of work of all the agencies, both public and private. It must know the strengths of the community and weaknesses as determined by careful research. It must know how to mobllize the leadership forces in the community and how to direct them into the most productive chanrels.

In spite of plans and ideals for the smooth functioning of the council, there are certain obstacles that must be overcorne in order to achieve its purpose. Often individual agencies resent another organization's planning for their contribution to the comrunity plan. There is a real possibility of conflict between the lay and prof essional groups as they view soctal problems, for each has a different point of view. Two other factors may also create difficulties. The council lacks any legal authorIty, as it was mentioned above, and it lacks responsibility for the agency budgets. Each of these could prove to be almost insurmountable, but by following the philosophy of the council and by using a little education mixed with 
cooperation most difficulties can be ironed out.

The purposes of councils of social agencies end the related aspects of philosophy, the knowledge that helps councils achieve their purpose, and $t$ he difficulties they may encounter have been discussed in general terms. Some of the mare specific activities that faIl within the scope of $\varepsilon$ council of social agencies are described in the following paragraphs.

\section{Activities}

Social planning is the broad heading that describes the field of activity pursued by councils of social agencies. It may be long term planning, or it may involve the meeting of some imnediate problem. But all activitles that are customarily carried out by councils usually fall into any of the four general categories; education, direct action, administrtion, snd cooperation. No activity, of course, is confined to one specific area, but there is a natural overlapping.

Education, one of the broadest activities of the council, is of three types: (1) education directed toward the members of the council, (2) education directed toward the community, and (3) education of agency staffs. The first is carried on through attendance at meetings and service on comittes. Community education is carried 
forward by informal interpretation and by definite publicity methods. Staff education is encouraged through institutes or classes conducted by the Council.

The role of the council of social agencies in social action has come up for mach discussion. Some feel that the council should be more militant in the area of direct social action, and others feel that it should be more conservative. However, councils usually indulge in direct action under certain circumstances. The council may actually sponsor a project, or it may serve as a pressure group to secure a desired social change, but more often it vill give support and direction to projects of benefit to the comunity when initiated by an agency or a responsi-. ble group. Community Chests and Councils, Ine., lists five specific methods used by councils in the field of direct action.

1. Special comnittees

2. Publicity

3. Personal contacts

4. Offers of practical service or assistance

5. Temporary financing ${ }^{1}$

Because of the relationship of the council to the various comnunity agencies, it is in a position to administer certain services that are of benefit to all agencies and to the community. In most cities the social service

${ }^{I}$ What Councils of Social Agencies Do, p. 23. 
exchange or social service index is administered by the council. In cities where the council has an adequate budget the technical services of a consulting psychiatrist or a consulting nutritionist are often provided. Volunteers' bureaus are frequently under the direction of the council. Perhaps the greatest service adminfstered by the council is that of fact finding or research. This service provides a factual foundation and undergirds all good social planning, and it includes special research projects and surveys as well as the continuous collection of basic data. Coordination is, probably, the one function that is most frequently thought of as an area of activity of a counc1l. No community has yet devised a perfect plan for all agencies, so one of the first jobs for a council is to coordinate the established procedures that have accumulated through the years. The council also plans, sponsors, or develops joint enterprises in the community. The publication of a social service directory is a valuable activity in this fleld.

\section{Methods}

How well a council can perform the activities we have been discussing depends to a great extent upon the methods it employs. We shall not discuss specific methods, but we shall generalize rather freely. The non-authoritarian 
position of the council makes it clear that its methods must be of a democratic and educational nature. Since the councils are usually organized on a functional-divisional, and committee basis, the conference method is used. In the begin ing the idea was that when two or nore agencies were drawn together around a conference table to discuss their mutual problem there would be an exchange of ideas, a developing understanding, and that out of $t$ his would come a solution to the problem. Councils have become more scientific, and their conferences are more frequently based on aiscussion of scientific data that have been submitted by the agencles and complled by the council research committee. The old advantages of the conference method are still at work with the addition of a more scientific basis for their discussion.

\section{Extent of councils today}

Today 262 councils of social agencies or similar federations in the United States are listed in the directory of Community Chests and Councils, Inc. Councils are found in twenty-six cities that have a population of 500,000 or more; in cities having a population of between 100,000 and 500,000 , eighty-six are found to have councils; 150 cities 
1

under 10,000 population have councils. These data ind1cate that council development has taken place in urban areas and parallels the whole field of soclal work, for not until recent years was social work extended to rural areas.

Effect of war on the councils of social agencies

In cities where councils of social agencies have been organized, the foresight of the founders of the councils has been justified over and over again since the war. Agencies had acquired experience in cooperative action; and when the rar emergency arose with its train of problems, the agencles were rapidly able to mobilize their resources. In many councils committees were at work on war connected problems before the Defense Councils were organized.

In cities where there did not exist instruments for joint planning the force of events often brought them into being under the Defense Councils. The dramatic happenings of war have brought home the realization that there must be understanding and cooperation between health and

${ }^{1}$ Compiled from statistics in Communtty Chests and Councils, Inc., Directory, 1942. (Population figures include metropolitan districts) 
welfare agencies and other organizations to help mobilize the resources of the community for war. Paul Benjamin, while executive secretary of the Buffalo Council of Soclal Agencies, made this statement in a recent annual report:

Increasingly a great truth is emerging, that 'Wars are won by people, ' that only a united people, strong in the will to preserve the democratic way of life, firm in the belief in the dignity of human personality, determined to strengthen the basic rights of people, including minorifies, can win both the war and the peace to follow.

Just as the last war gave an impetus to the community chest movement, so this war may invigorate our working together for the common good.

\section{Summary}

The principle of cooperative action and joint planning to meet the community problem was most definitely carried out in the late Nineteenth Century by the Charity Organization Socleties. As their function changed to giving direct service to clients, the need for an organization to meet the increasing problem of duplication of effort on the part of the social agencies continued. In 1909, the first councils of social agencies began, and following the first World War the number of councils has increased steadily until today there are 262 in the United

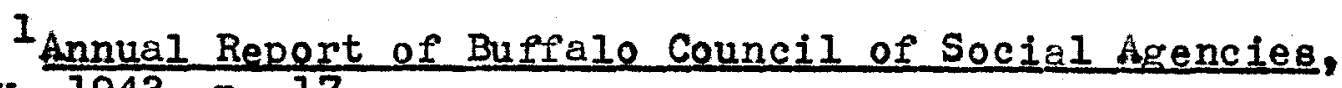
January, 1943, p. 17 . 
states. The councils are customarily composed of lay and professional delegates from both public and private agencies. An executive secretary is employed to coordinate the work of the council.

The general objectives of the councils are to secure better social and health services for the community and to relate them to the communities' needs. The objectives are conducted through certain activities that are usually related to education, direct action, administration and coordination. The underlying philosophy of the councils is based on democratic and educational principles as demonstrated by its methods.

A second world war has focused the need for unity in ell aspects of comnunity life; and, when existent, the councils have come farward to contribute their best efforts toward this unity. In communities where there have been no organizations for jolnt planning, this need has been stimulated. The consensus of opinion seems to be that in most communities the war has not created new proble ms but has intensified old problems. If this is the case, an efficient functioning council of social agencies is the logical organization to which these problems should be assigned. 
CHAPTER II

FIRST STEPS TOWARD COORDINATED SOCIAL PLANNING

IN LOUISVILLE- - 1884-1925 
CHAPTER II

FIRST STEPS TOWARD COORDINATED SOCIAL PLANNING IN LOUISVILLE--1884-1925

Louisville has not deviated from other cities in the established pattern of development of mutual planning of social agencles. Recoräed material does not indicate the events that were taking place leading to the formation of some organization for social planning, but we do know that in 1884 the Charity Organization Society of Louisville was formed. Its principles, expressed in the constitution, included coordination of existing charitable organizations and institutions to eliminate duplication of relief giving and the promotion of social and sanitary reforms. Coordination was attempted for several years with a disappointing lack of success.

Miss Bateman notes in her study that, at the annual meeting of the Charity Organization Society in 1900 ways and means of obtaining cooperation anong the local agencies were discussed. As a result of this discussion the president of the Charity Organization Society proposed a conference in Louisville "for mutual information and planning

$I_{\text {Material concerning The Charity Organization }}$ Society taken principally from Bateman, op. cit. 
along philanthropic Iines." ${ }^{1}$ The first meeting washeld In January, 1901, with representatives of the Kindergarten Association, Neighborhood House, The Charity Organization Society, the Hebrew Relief Society, the Kentucky Children's Home Society, and the Humane Soclety. A conference for the union of all city charities was held following this initial meeting.

In 1907, the Charity Organization Soclety became the Associated Charities. With this change several new comnittees were formed, one of which was the Case Committee. Accoraing to the By-Laws, the functions of the Case Committee were as follows:

The Case Committee was to be composed of a chalrman, who was expected to be the Superintendent anless the Board desired to elect someone else, and the representatives of such philanthropic, religious, and charitable organizations of the City as cared to confer with him concerning cases coming before such organizations where cooperction with or assist ance from those organizations was deemed advisable. 2

As it was created, the Case Comnittee operated as a part of the Associated Charities, but Miss Bateman points out that it might be sald to have been a forer runner of the Council of Soclal Agencies. She goes on

\section{Ibid., p. 56}

Article IX, "Standing Committees and Their Duties," By-Laws of The Associated Charities as amended July 2 , 1917, quoted in Bateman, op. cit., p. 67. 3

Ibtd. pp. 72-73. 
to tell something of the work of the Committee:

The meetings of the Case Comittee were given over to discussions of problems arising in familles under the care of the Associated Charities or one of the other organizations represented, and by having all of the representatives together, it was found that 'a clear understanding of the situation may be reached and the resources of the city brought to bear to remove the causes of the trouble.' Duplication of effort was prevented. 1

In 1922, the Associated Charities took the name of the Family Service Organization apparently without making constitutional revisions. The Case Committee continued in name only since its activities were assumed by the Community Council of the Welfare League and later by the Family and Child Welfare Council of the Community Chest. When the Family Service Organization amended Its Constitution in 1928 the Case Committee was discontinued as such.

Characteristic of the period about 1916-1918 was the movement toward federation of agencies for coordinated fund raising and social planning. A Federation of Social Agencies was established in Louisville in November, 1917, after two years of study on the part of interested cit1zens. It consisted of twenty-five social organizations united for financial, social, and educational effort and

1 Ibid., p. 74 . 
was the parent body of the present community Chest. According to its Constitution its purposes were explained as follows:

1) The collection and distribution of funds

2) The operation of the Social Service Exchange

3) The supplying of accurate information on welfare noeds. It studies needs and tries to meet them through existing organizations or creates new ones. It brings to bear on these problems the conmon intelligence, combined resources, and unified action of the federated organizations in cooperation with all other agencies, ${ }_{1}$ public and private, interested in the same problems.

This organization was created to combine the functions of federated social planning and fund-raising. Several months later the Federation of Social Agencies delegated its social planning function to a newly formed Community Council, which was described in The Community ${ }^{2}$ as follows:

Of great importance for promoting concerted action on Louisville's welfare problems is the recent organization of the Louisvilie Community Council, made up of all organizations, federated or unfederated, public or private, religious, $s \propto 1 a l$, or $\xi^{1 v i c, \text { in any way }}$ concerned with the public welfare. 3

Its purposes and methods, expressed in 1ts const1tution, are:

1. The Community council is an informal grouping of $\mathbf{s} c i a l$, philanthropic, and civic organizations and activities to establish a complete understanding 1917.

${ }^{1}$ constitution of the Federation of Social Agencies, 2 A small magazine published by the Federation of Social Agencies.

3 The Community, July 5,1918, p. 3 . 
among the many age ncles whose flelds of work touch; to further cooperation and to prevent duplication of effort; to serve in an advisory capacity concerning new work to be undertaken; and to increase efficlency of work already done. The Council is not concerned in the collection or distribution of funds. It cannot bind any of its members to any policy or action.

2. Any organization or activity having for all or part of its proper function some concern in the pubilc welfare is eligible for membership in the Community Council.

3. The Community Council shall be made up of two representatives of each member organization of whom one should be a pald worker.

4. Headquarters are to be furnished and expenses paid by the Louisville Federation of Social Agencies. ${ }^{1}$

The outstanding plece of work accomplished by the Community Council in the first year of its existence was the Child Welfare Study carried on by the Child Helping Department of the Rusiell Sage Foundation. This study was initiated by the Community council and financed by the Federation of Social Agencies (which became the Welfare League in January, 1919). The study covered all the agencies and activities directly related to the child Welfare fie ld and included a brief survey of closely affiliated activities. The findings of the study were published by the Welfare League in 1919. The following specific recommendations were made to the Community Counc il:

It is recommended that a Child Welfare Committee

${ }^{1}$ Constitution of Community Council, 1918. 
be appointed to investigate propositions for advance movements, to formulate plans for action by the Council and its constituent organizations, to indicate modern and progressive methods of work, to advocate specific city and state programs of systematic service, and to draft bills for new laws to be presented to the Stafe Iegislature, or new ordinances to the city council. 1

In addition to initiating the study, the other activities of the council consisted of "meetings and consultations for mutual understanding and advocacy of progressive movements." The Amual Repont for 1918, stated that the council was going ahead with its child welfare work on the basis of the Russell Sage Study and that it was going to meet other community problems through groups composed of representatives from all organizations interested in specific subjects.

At an Executive Committee meeting of the council in April, 1919, 'a plan for enlarged activities was discussed and it was proposed that the council be organized into such functional groups as public health, education, industry, leisure time, dependency, delinquency and crimes, and civics. The work of the council during the

${ }^{1}$. H. Slingerland, Child Welfare Work in Loulsville, (Loulsvilie: The Welfare League, 1917) pp. 102-103.

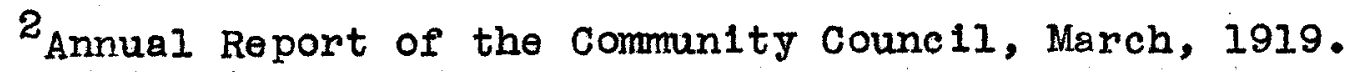

${ }^{3}$ Minutes, Executi ve Committee, Community Council, Apri1 8, I919. 
year 1919 was briefly summarized in a report in The Community. The continued influence of the child welfare study was credited with bringing about the establishment of a social training course at the University of Louisville for instructing social workers, a Psychological Laboratory, the transference of the Home for Friendless Women to the Salvation Army, and the proposed consolidation of the Industrial School of Reform, the Detention Home, and the Parental Home. A Child Welfare Committee was organized to continue the execution of the recommendations of the study.

In adition, the accomplishments of the other functioning committees were described. The Housing Committee worked for an improved housing code and planned to continue its work in seeing that the law was enforced and that a City Planning Committee be farmed. The Soclal Hygl ene Committee made it possible for Wayfarers' Lodge to be avallable for venereally infected women. The Mental Hygiene Comnittee supervised the work of the Psychological Laboratory and tried to secure sufficient appropriations to increase the facilities of the State Institution for Feebleminded at Frankfort. The Committee on Boarding Homes made a study of boarding homes for

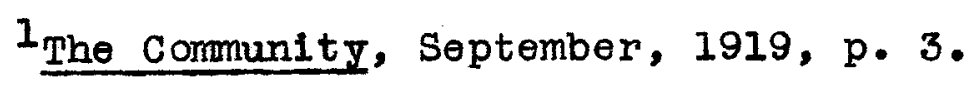


working girls. The Committee on the Social Service

Exchange was active in an advisory capacity.

Durling these first two years Elwood Street was acting as director of both the Felfare League and the Community Counc11. On January 1, 1920, Raymond A. Hoyer, formerly with the War Camp Community Service was employed as the Executive Secretary of the Community Counc11. An office separate from the Welfare League was established, and having been incorporated as a separate organization, the Council received the endorsement of the Board of Trade. Among the activities of the council in 1920, were the preparation of a social service directory, the creation of a bureau for volunteers, the organization of classes in play and games, and the establishment of a strong Health Cormittee. During this jear the centralization of the activities of the council, the central Purchasing Bureau, the Social Service Exchange and the Psychological clinic was accomplished. The work of the council was described briefly in the Social Service Directory:

The Council has advised with various local agencies on their problems and has attempted to bring about a closer cooperation among the organizations and

\section{${ }^{1}$ Ibid.}


workers by interpreting methods and underlying principles. 1

The Annual Report for 1920 stated that the Council included in its membership seventy-four affiliated groups and fifty-two other agencies that cooperated but were not affiliated.

Shortly before the end of this first year the budget of the Community Council was discussed by its Executive Comitter. During this discussion the desirability of continuing the work of the council was considered. After the various representatives expressed their opinions on the work, it was the unanimous opinion of the committee that the council should continue.

A year passed and it was again time to consider the budget for the council. The Executive Committee of the Welfare League suggested the consolidation of the Council and the League. This proposal was discussed by the Executive Committee of the community Council, and, as a result, a motion was carried that the two organizations consolidate. Although this action was taken, it is interesting to note that the Executive Committee was

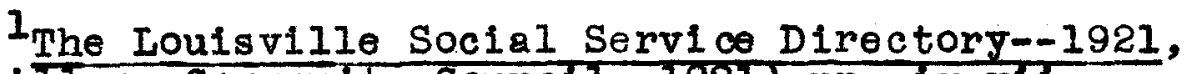
(Loulsville: Community Counc11, 1921) pp. iv-vi1. 1921.

2 Annual Report of the Community Council, April, 3 September̆ 21,1920 .
} 
aware of some of the problems involved in such a move and these recommendations were made to the League:

It was the sense of the meeting that every effort should be made to impress upon the Welfare League the importance of having someone definitely responsible for the continuance of the activities now conducted by the Council. Several members seemed to feel that the Welfare League would find it impractical to. continue the militant program now conducted by several of the comittees of the Council since it would react unfavorably upon givers who might be offended at some of the policies.

In October, representatives of the Executive Committee of the Council met with the Executive Committee of the League and after some of the problems involved in consolidation were pointed out, the Welfare League decided not to consolidate. However, the League had financial control and since 1921 had been a depression year, the League felt that in vi ew of its finencial situation 1t could grant a budget of only $\$ 1,500$ for 1922 instead of the $\$ 3,300$ granted for the previous year. The Executive Committee of the Council considered this offer and decided that the amount was so insufficient that unless more funds were made avallable it would be better to disband on January 1, 1922.

No further comments were made on this decision

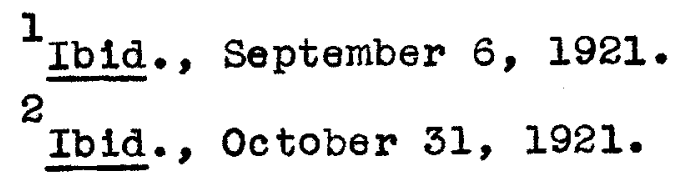


In the minutes of the Community Council, but the Annual Report of the Helfare League stated that the council was discontinued on December 31, 1921:

... because in the opinion not only of Raymond Hoyer, Executive Secretary of that organization, but also of the Executive Committee of the Welfare League the activities carried on by the council could in a large measure be taken over by the League, since the Welfare League itself is interested in the soclal work of the community at large as well as the financing

of its twenty-nine agencies. 1

The Welfare League delegated the social planning work to the Board of Workers, one of the two existing divigions of the Welfare League. It was composed of the executives of the member agencies. The Board of Presidents of the League was made up of the presidents of the boards of member agencies. According to the by-laws of the Board of Workers, its purpose was "to study and make recommendations or take action upon matters concerming the common needs of the member agencles and the social needs of the community." ${ }^{2}$ Again as under the Federation of Social Agencles, social planning was carried on in the same organization with federated financing, and no full time paid executive was employed. When the Welfare League took over the functions of the

${ }^{1}$ Annual Report of the Welfare League, 1921.

${ }^{2}$ Article I, By-Laws of the Board of Workers of the Welfare League. 
Communty Council it was necessary to provide some means of participation for agencies that were not in the League. As a result, representatives from non-League agencies were invited to participate in the activities of the Board of Workers as associate members.

During 1922, the Board of Workers held eighteen meetings as a result of which some progressive action was taken. Several studies were made to establish the need for certain community services. The adequacy of playground facilities for the Negro people was questioned, and a committer was appointed to go into this matter more thoroughly. The Board was requested by a group of Negro women in the city to consider the need for a home for Negro unmarrled mothers. The question of how the women incarcerated in Loulsville spent their leisure time led the Board to appoint a committee to study deIinquent women. Various agencies requested that a study be made of the available care for feebleminded children of Iouisville since the Feobleminded Institute at Frankfort was overcrowded and the agencies were no longer able to meet the financial responsiblilty themselves. Other activities of the Board consisted of urging the appointment of a trained person as Chief Probation Officer of the Juvenile Court; of approving the Louisvilie Conference of Soclal Workers sending a telegram to the governor of 
Tentucky asking him to veto the bill repealing the Housing Law which was passed in 1920; and of taking an active part in the re-establishment of the School of Social Work affillated with the University of Loulsville. The Board also organized a Case Conference Committee to study specific cases with which several agencies had contact and broad community problems such as illegitimacy, which was similar to the function of the former case committee of the Associated Charities.

Seventeen meetings of the Board of Workers were held in 1923. Problems considered during this year were: begging children, the need for an employment bureau, difficulties of distributing Christmas gifts without duplication, illegitimacy legislation, and inter-agency relations and functions. The work of the Central Purchasing Bureau, and the Social Service Exchange was continued by their comittees in the Board. The Board, recognizing the need for proper institutional care for the dependent chronic invalid, convalescents, and the aged and infirm, passed a resolution urging the city of Louisville to provide the necessary care for this group. As a result of the request of the Kentucky Child Welfare Commission that the Board of Workers organize a comittee on recreation that would invite into its membership representatives of all organizations in Loulsville dealing 
with the recreation problem, the Recreation and Outings Committee was appointed.

The Board of Workers, having been composed entirely of the paid executives, had certain limitations based largely on the fact that no agency board members were Included. Its advantage, on the other hand, was that these executives, without their "bosses" present felt that they could talk more freely.

In January, 1924, the Welfare League disbanded and the Community Chest was formed. There was some question about the continued existence of the Board of Workers for they felt there was need of an organization composed of executives to discuss problems of social planning and organization, but this group was discontinued as such when the Community Chest was formed. Mr. David Liggett, Executive Secretary of the Loulsville Community 1 Chest, explained in an adcress before the Board of Workers that it was hoped the new organization of the Chest would eliminate the lack of coordination between the Board of Presidents and the Board of Workers.

Summary

If the formation of the Charity organization

$1_{\text {David Liggett was Executive Secretary of the }}$ Louisvilie Community Chest from July 1, 1921 until March $15,1928$. 
Society is considered as the beginning of a program for coordination and social planning, it can be said that Loulsvilie has had some form of social planning since 1884. Under the Charity Organization Society and the Case Committee of the Associated Charities which followed the Charity Organization Soclety the basic principle was that through greater knowledge of the work of all agencies and through discussion of difficulties a greater understanding would be arrived at. There was no attempt at long term social planning since their central interest was to seek cooperative action on cases that were joint problems. It was such early thinking as this that made possible in 1917 the movement toward federated financing. Following the formation of a central financing agency, a Community Council was formed to carry out the social planning and coordinating function that had been delegated to the Federation of Social Agencies (that later became the Welfare League). Representatives from League and non-League, public and private agencles were invited to membership in the counc1l. The Council operated for two years with the Executive of the League as its secretary, but in 1920 it secured the services of a separate pald executive. Under the Communlty Council its activities were organized on a functional commlttee basis. 
An analysis of the various projects executed by council shows that they could be arranged under the four descriptive classifications of activities of councils of social agencies, i.e., education, direct action, coordination, and administration.

In 1922, the Community council was disbanded and its functions were taken over by the Board of Workers of the Welfare League. During the two year period of operation of this group as a social planning body numerous studies were conducted to determine community needs and gaps in agency services. There were a few ingtances where direct action was used to remedy a situation, and the Board of Workers continued the interest that the Community Council had in education. Education at this time was directed toward the development of staff members and toward the enlightenment of agencles about the problems in the community. Iittle interest was shown in interpreting social work to the community.

At the end of two years, it was felt that the form of organization was not satisfactory since so little interaction and cooperation existed between the Board of Presidents and the Board of Workers. However, this was not altered since the Welfare League was disbanded in January, 1924, with the arganization of the community chest, and the Bourd of Workers was also discontinued as such. 
CHAPTER III

THE ORGAINIZATION OF THE COMMUNITY CHEST

AND ITS SOCIAI PLANNING PROGRAM, 1924-1927 
THE ORGANIZATION OF THE COMMUNITY CHEST

AND ITS SOCIAL PLANNING PROGRAM, 1924-1927

\section{Organization}

The Louisville Community Chest, formed in 1924, was primarily a fund raising organization; however, it was realized that intelligent financing of social agencles could not be accomplished without adequate knowledge of the problems in the community and the quality of services needed to meet them, and provision for social planning was made in the chest constitution.

The method followed in the re-organization of the Welfare League into the Community Chest throws some light on the organization history of the social planning bodles that were set up--the Recreation Council, the Health Council, the Family and Child Welfare Council, and the Advisory Council.

From June, 1923, the Executive Committee ${ }^{1}$ of the Welfare League had been considering the possibility of the re-organization of the Welfare League to form a

$1_{\text {The Executive Committee of the Welfare League }}$ was composed of five members of the Board of Presidents appointed by the President of the Community chest plus the President of Chest and Executive Secretary. 
Community chest, and the question was discussed with numerous executives and board members. The Electric Club, the president of which was also president of the Presbyterian Collored Mission, a member agency of the Welfare League, passed a resolution calling upon the Round Table to request the Mayor to appoint a committee to study the possibility of the formation of a community Chest. Mayor Quin acted favorably upon this suggestion, and the requested committee was appointed. The Welfare League itself necessarily fell well into the background of this project and secured the strategic position of not being the originator or pusher of the movement. This position was apparently quite wise owing to the fact that so many agencles outside of the Welfare League were prospective members of the re-organized Chest. Mr. Embry I. Swearingen, the chairman of the Mayor's Committee after visiting eighteen Chest cities, reported his findings to this comittee on November 16 , 1923. After a general discussion a motion was passed to approve the formation of a Community Chest for Loulsvi11e. 1

On November 30,1923 , a large meeting made up of

${ }^{1}$ Executive Committee Meeting of the Boerd of Workers of the Welfare League, November 22, 1923. 
representatives from all possible members of the chest, Welfare League Agencies Included, was held and at this time a tentative constitution and by-laws were considered. On December 27, the organization meeting was held in the Aldermanic Chamber of the city Hall. The final Constitution and By-Laws were adoped. Ten organizations in adition to the thirty-three Welfare League agencies composed the Community chest.

In the handing of this whole project the Welfare League and the Board of Workers apparently played a "behindthe-scenes"role. The initiation of the 1 dea came from the outside--the Electric Club; the comittees were appointed by the Mayor and the meetings were held in the City Hall.

Returning to underlying ldeas beind the writing of the Advisory Council provisions in the Chest const1tution, it seems that it was the idea at that time that through this device board member participation and representation from public and private agencies who would never be actually affiliated with the chest could be secured. There evidently was great uncertainity as to just what type of organizational plan would eventually be evolved under the head of Advisory Council, although

${ }^{1}$ Courier-Journal, December 28, 1923. 
the records do not definitely state this. The Constitutional provisions of the Community Chest were left broad so as to enable the Advisory Council to work out its own plans.

First, the Case Work, Recreation and Health Councils were formed and following the completion of their formal organization the question was ralsed as to what form the Advisory Council provided for in the Constitution of the Chest should assume. A meoting was called on September 8, 1925, for the purposes of discussing the formation of the Advisory Council. Representatives from all the social agencles in the community were invited. It was the idea at that time to secure, if possible, representatives from all of the organizations affiliated with the three councils as members of the Advisory Counc11.

During the discussion at the meeting the question arose whether the Advisory Council would be on a basis similar to the old Board of Workers in the Welfare League and what the relation of the othe $r$ three Councils would be.

After several organization meetings the Advisory Council was finally formed with a membership of the Executives of the Community Chest Agencies and the 
Executives of four non-Chest agencies.

This group met irregularly and trangacted little business. It may be presumed, although it is not definitely stated in the records, that the Advisory Council was indefinite as to exactly what 1ts role was. A change in the organizational plan was proposed in $1925,^{1}$ but it was not presented to the Executive Committee of the Community Chest. In March, 1926, the Advisory Council again considered proposals to change the Articles of Agreement but since there was a plan being worked out to change the By-Laws of the Chest which would affect the Advisory Council no action was taken on this matter. At length, the proposed revision of the By-Laws of the Community Chest was adopted in December, 1926. These By-Laws eliminated the Advisory Councll as such and embodied provisions for a new social planning body known as the Social Planning Committee.

The Social Planning Committee was to be composed of fifteen members plus the secretaries from the three sub-councils. This included the president and the executive of the community Chest, one member each from

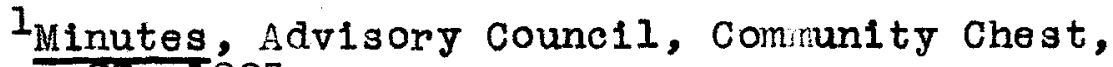
September $22, I 925$.

${ }^{2}$ Ibid., March 23, 1926. 
the Executive Committer, Finance Conmittee, Budget Committee, two members from each of the Sub-Councils, and four members-at-large. The function of the Social planning Committeo was to consider all social plans and projects of common concern to the member agencles and to serve in a coordinating capacity in reference to the three councils. Thus "all social plans and projects of common concern" were to be referred through it. The Social Planning Commlttee was organlzed and held an inftial meeting in June, 1927, but it remained in an undeveloped state and soon was 1nactive. In this respect the constitution of the Chest was 1gnored.

When the by-laws of the community chest were revised in 1926 the Family and Child Welfare, Recreation, and Health Councils were provided for for the first time by the chest. 3 The revised constitution also gave the Councils the authority to select their own secretaries subject to the approval of the Executive Committee of the chest and provided for the chairmen of each of the

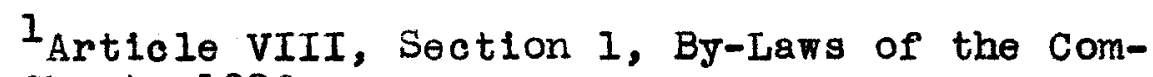
munity Chest, 1926.

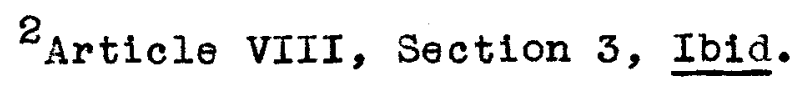

3 Article VII, Section 1, By-Laws of the Community Chest, as revised, 1926.

4 Ib1d. 
Councils to serve as members of the Executive Committee of the chest.

During 1924, Dr. Haven Emerson conducted a survey of the health and hospital facilities in Loulsville, and upon its completion the Health Council was formed in March, 1925, to carry out the first recommendation of the survey.

The Constitution of the Health Council provided for agency membership as follows:

Any public or private agency conducting services for bealth or caring for the sick may apply for membership in the Health Council and will become a member if approved by the Council. 1

Each agency holding membership had two delegates to the council, one of whom was the paid executive. In addition to the agency delegates, the constitution made provision for the election of fifteen members-at-large.

Dr. Emerson's Health. Survey gained wide community attention, and as a result of the strong community backing which was stimulated, the Health Council was provided with an executive secretary in March, 1925, by the Chest. The person selected was Miss Anna Phillips, who had assisted Dr. Emerson with the Louisville survey. It was understood that she would be employed for one year to

${ }^{1}$ Article III, Constitution of the Health Council, (no date but thought to be the original one). 
establish the organization of the Health Counc1l. The Chest allowed the Health Council a budget of seven thousand five hundred dollars for 1925, the largest part of which was paid to the executive and a small stenographic staff.

Other changes in organization were to come but certain accomplishments were attained during these early years of formation.

In the meantime the development of the three Councils was taking place with the understanding that they would be perts of the Advisory Council.

The Recreation Counc11 ${ }^{2}$ was organized on May 23, 1924, after the Louisville Conference of Social Workers passed a resolution requesting the Mayor of Loulsville to call a conference "representing the Park Board, the School Board, the Woman's Club, the Lions Club, the Rotary Club, the Settlement, the Associations, the Churches, the Board of Trade, the Kentucky Child Welfare Commission, and the community Chest to consider the problem of recreation in Loulsville. 3 The Recreation

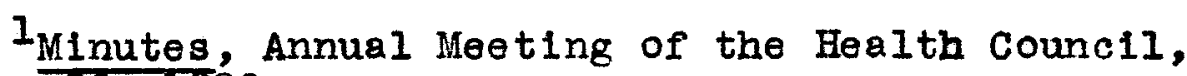
February 26,1926 .

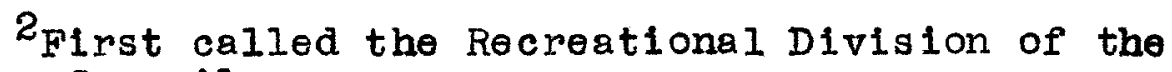
Advisory Council.

${ }^{3}$ Minutes, Recreation Council, March, 1924. 
Council was formally set up and a constitution was adopted on June 11, 1924 .

Membership in the Recreation Council was of three types: organization members, individual members, and associate members. To become eligible for membership In the Recreation Council and "agency or organized group must be interested in furthering the objects of the Recreation Counc1I" and must secure the approval of the Executive Committee of the Recreation Council. Delegates to the Recreation Council consisted of two representatives from each member agency, usualiy a board member and the executive. Provision was also made for the election of community at large members not to exceed the number of member agencies and for the inclusion of staff employees as associate members of the Councils. All members had one vote, except the associate members who were not given this privilege.

The officers of the Recreation Council consisted of a chairman, vice-chaiman and secretary who were elected annually. The executive was selected by the Chest subject to the approval of the board of the council.

\footnotetext{
$I_{\text {Articles of Agreement of the Recreation Council }}$ of the Advisory Counc1l, Article II, Section 1, June, 1924. ${ }^{2}$ Ib1d., Article IV, Section 2 .
} 
The Council had an Executive Committee that was usually composed of the officers of the council, the chairmen of the standing committees, three members appointed by the chaiman of the Council, and the Executive Secretary of the chest as an ex-officio member. This committee varied in size from time to time, but its function continued to be that of performing the duties of the Council between meetings.

The Recreation Council was not organized with the burst of enthusiasm that was later present at the formation of the Health Council. The pathos that iliness cen create was lacking in a movement concerning recreation, or what the public probably called "play." In spite of the apparent lack of community-wide interest at the beginning, the Recreation Councli did have the cooperation and interest of the recreation and social agencies in the clty.

During the first year and a half of its existence. Miss Mary Stotsenburg of the Communtty Chest served as its secretary. The Council did not recelve a budget from the chest but was finenced by the registration fees from two training courses conducted by the council and by proceeds from the sale of the Manual of Play published under the direction of the Training committee of the council.

$1_{\text {Minutes }}$, Recreation Counc1l, September 15, 1925. 
In November, 1925, the plan was suggested, since it had been proposed to turn the School of Social Work over to the University of Louisville, that the Chest continue paying the salary of the two teacherg, one in casework and one in recreation. Then the two workers would act as paid secretaries of the Case Work and Recreation Councils. Evidently the Chest granted this request for Miss Stotsenburg no longer served as secretary and Miss Ida Levin, former Director of the Recreation Department of the School of Social Work assumed her dutles as secretary of the Recreation Council on January 1, 1926. The Recreation Councll did not recelve a budget for the first six months of Miss Levin's service, but the Chest allowed the council a budget of $\$ 2,275$ for the period from June 15, 1926 to December 21, 1926. Apparent1y, from January to June, 1926, Miss Levin continued her connection with the School of Social Work and recelved compensation for her services from that source.

Illness forced Miss Levin to take a leave of absence from October, 1926, unt1l January, 1927, but a substitute was employed until her return.

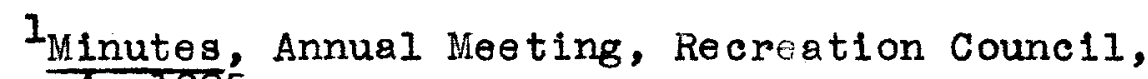
November $\frac{1}{4,1925}$.

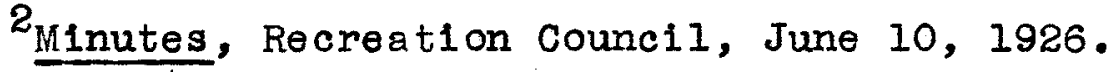


A budget of $\$ 2,275$ was appropriated for the Recreation Council for 1927, whlch was the same amount that the council bad received for one-half a year in 1926. At a meeting of the Advisory Committee of the Counc1l, Mr. Liggett, Secretary of the Chest, sald that be did not believe that it was the intention of the Executive Committee of the chest to take drastic action in regard to the future of the Council. The Executive Comittee appointed a committee to study the work of the three councils and to make recommendations as to their future. It was explained during the course of the discussion that a number of large contributors to the chest had reduced their subscriptions because they belleved that the Councils were "frills" and did not understand the work they were accomplishing. It is significant that the representatives from the recreation agencies offered to cut their own budgets in order to turn the extra amount to the Recreation Council if it would keep the Council alive. The outcome was that a final budget of $\$ 5,738.35$ was granted for 1927 .

During the following months, several individuals March $3, \frac{1_{\text {Minutes }}}{\text { I92\%. Advisory Comittee, Recreation Council, }}$
$\quad{ }^{2}$ Ibid. 
In the chest and Councils were involved in a conflict which centered around personalities, and Miss Levin resigned June 24,1927 . Since the position of the Councils was undecided no executive was selected to flll her place during 1927.

On September 25,1924 , a preliminary meeting was held to discuss the formation of a Case Work Division to be one of the three functional groups in the Advisory Council, whlch had not yet been set up. The explanation was that Articles of Agreement and a general plan of work should be drawn up before a constitution could be drafted for the Advisory Council. The first Articles of Agreement of the Case Work Division were adopted on October 30 , 1924.

The organization of the Case Work Division was like that of the Recreation Council with a few exceptions. According to the Articles of Agreement of the Case Work Division the following agencies could become members of the Division:

Any soclal agency or other organized group kindred in activity to case work and interested in furthering the objects of this Division is entitled to membership in the Division after securing the approval of the

${ }^{1}$ Meeting of the Case Work Division of the Advisory Counc11, September 25, 1924 . 
Executive Comittee.

The Case Work Division had the same classifications of membership as the Recreation Council and the same type of delegate representation, however, assoclate members of the Case Work Division had a vote. The officers and the Executive of the Case Work Division were selected in the same manner as the Recreation Council, and an Executive Committee was also organized.

The organization of the Case Work Division was completed in october, 1924, but the offlcers were not elected until Warch 26, 1925; also at this meeting the name was changed to the Case Work Council. Since the Articles of Agreement of the Case Work Council provided that the secretary of the council should be a member of the staff of the Community Chest, Miss Mary Stotsenburg was made secretary of the Case Work Council on March 26 , 1925. Miss Stotsenburg did not serve the Council on a full time basis but continued her position with the Chest. At a meeting of the Case Work Council on November 5, 1925, the motion was passed that the community Chest be requested to finance a budget for employing a full

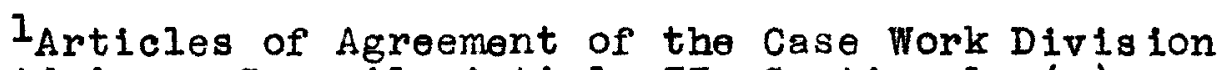
of the Advisory Counc11, Article II, Section 1. (a), September, 1924 .

${ }^{2}$ Ibid., Article IV, Section 1 .

3 Minutes, Case Work Council, March 26, 1925. 
1

time executive secretary of the Council. In December, 1925, Miss Stotsenburg resigned and Miss Mary Brisley of the School of Social Work was elected secretary. At this time the Council decided to change the name of the group to the Family and Child Welfare Council with the purpose of embracing the entire fleld of work for the family and child not covered in the Health and Recreation Councils. Miss Brisley served until her resignation upon acceptance of a position in another city. Here followed an interim with no secretary until Miss Annabel Kahn was prevailed upon to serve for a time. She accepted the responsibility of recording minutes and sending out notices only, since she was on the staff of another agency. On January 17, 1927, Mr. Paul Benfamin of the Family Service Organization consented to relleve Miss Kahn.

During these months the council in its meetings and the Executive Committee of the Council had discussed the need for a paid executive. Each year the Chest failed

${ }^{1}$ Ibid., November 5,1925 . Ch1ld Welfare Counc1l, March 29, 1927.

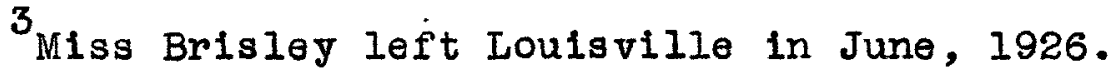

${ }^{4}$ NOW Mrs. Annabel Kahn Snowden.

5 Minutes, Executi ve Committee, Family and Child Welfare CounciI, January 17, 1927. 
to meet its campaign quota and the re were no funds with which to employ an executive for the Council. The Recreation and Health Councils continued with their secretarles and the Family and Child Welfare Council felt that it was being unfairly treated.

At one meeting the discussion centered around the question of considering a limited budget or one on the basis of those of the Health and Recreation Councils with a salary for a highly trained person as an executive secretary. Mrs. Halleck, Council Chalman, stated at an Executive Meeting on the same day that if the council could not have a paid secretary it would not attempt to function. The need was felt to be so urgent that it was even suggested that an ofilce secretary be employed to handle the detalls of the Council work leaving the case work plans to the various executives of the agencies. After Mr. Paul Benjamin outlined in detail the needs for a well trained executive, the group agreed that to function the council must have a pald secretary. At this time a resolution was adopted to the effect that a tentative budget of about six thousand dollars be presented to the

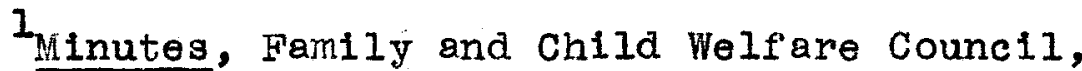
November 4, 1926 .

2 Minutes, Executive Committee, Family and Child Welfare Council, November 4, 1926. 
Executive Committee of the Chest.

In December, 1926, the Executive Committee of the Chest Informed the Council that an Executive could not be employed before April 1, 1927 when the results of the Chest Campaign were known. It was recommended that a salary of tro thousand seven hundred dollarg be set instead of the three thousand dollars requested. Evidently the Chest held out little hope for reaching the campaign goal for the advised the Council against offering the position to anyone until after the campaign.

Although a budget of $\$ 2,785$ was tentatively granted the Couneil for 1927, it was the feeling of the Executive Committee of the Council that when the Chest fell elghty-two thousand dollars short in the campaign the budget request should be withdrawn with the exception of three hundred dollars for incidentals. The statement was made that "research work cannot be done at the expense of relief for those in need." "Whether the council

${ }^{1}$ Ibid., November 9, 1926.

$2^{2}$ Ibid., December 29, 1926.

3 Ibid.

${ }^{4}$ Louigville Community Chest Campaign Goal for 1927 was $\$ 727,911.62$.

${ }^{5}$ Minutes, Executive Committee, Family and Child Welfare Counc11, February 21, 1927. 
desired to take this action or not, due to the circumstances there was no other choice. However, this discouragement did not cause the Council to lose sight of its ability eventually to eliminate many of the economic evils in the community through careful social planning. Evidently the Council questioned if all of the money expended on social services was spent in the wisest way for the following resolution was passed on February 25, 1927:

The Family and Child Welfare Council recommends for the consideration of the Execut1 ve Committee of the community Chest that a study of the organizations of the Chest be made for the purpose of making recommendations as to the relations of the finances to the social services performed.

It can be inferred that the council wanted to know and to have others know if a real need existed for a social planning body, such as the Council, to coordinate social welfare in the Community or if the people were already receiving the best possible services.

Again the Counc1l was faced with another year without a paid executive. Toward the end of the year meetings were held to prepare a budget for 1928. There seemed little likelihood that the chest would meet its campaign goal for 1928; therefore, the Chest proposed that the Pamily and Child Welfare Council, the Recreation

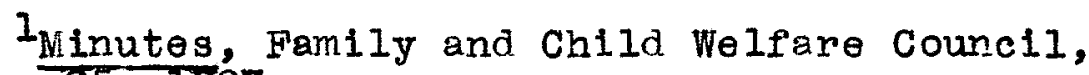
February 25, 1927. 
Councll and the Health Council combine their budgets and work out some satisfactory plan for the distribution of the funds. After discussing the suggestion it was the decision of the council that it was wise to continue to think of its group as a separate entity and to figure a budget on the basis of the needs of the council as if it wore running as an individual organization.

In February, 1928, the Executive Committee of the Family and Child Welfare Council recomended to its Council that:

.... it consider the advisability of working for one year with a paid executive with the understanding that at the end of that time there would be a thorough appraisal or survey of either the case working agencles or of all the social agencies. 3

At this time it was the desire of the council to engage Miss Herriett, Anderson as the secretary. However, Mr. Liggett resigned as Executive Secretary of the chest and since the situation was unsettled the Executive Committee passed the following resolution:

In view of the present unsettled condition of the organization of the chest office, it is suggested that no further expansion in the development of the

${ }^{1}$ Ibld., November $23,1927$.

$2_{\text {Ibid. }}$

3 Minutes, Executive Comittee, Family and Child Welfare CounciI, February 23, 1928. 
Councils be considered and that no executive be engaged by the councils until the present situation was clarlfled. 1

The Executive Committee of the Family and Child Welfare council directed the Chairman to explain to the Chest that work of the council would lapse if all further work were delayed until a permanent secretary could be retained. The council presented a request for the employment of a temporary secretary at a salary of $\$ 175.00$ a month with offices in the chest building. This request was granted and Miss Stotsenberg wrote that office facilities for the temporary secretary would be ready for her on the first of April. After three and a half stormy years the Family and Child Welfare Council was about to become organized for effective work.

$1_{\text {Minutes, }}$ Executive Conmitter, Community Chest, March 13, 1928.

$2_{\text {Minutes, Executive Committee, Family and Child }}$ Welfare Counc1I, March 14, 1928.

${ }^{3}$ Ibid., March 27, 1928. 
CHAPTER IV

ACTIVITIES OF THE RECREATION

AND FAMIIY AND CHIID WELFARE COUNCILS 
CHAPTER IV

\section{ACTIVITIES OF THE RECREATION \\ AND FAMILY AND CHIID WELFARE COUNCILS}

From the amount of discussion that has been devoted to the organizational aspect of the councils it might be thought that the formation of the Councils was an end in itself and not a means to an end. It is surprising how amid such turmoll and indecision that many good things were accomplished. Perhaps it was the presence of the lay-people who carried on the work of most of the committees that helped pull the Councils through their "agonies of birth." Doubtlessly the necessity for meeting the many problems in the community was of same value as a steadying influence.

In this chapter some of the specific activities of the councils are discussed and it would be gratifying to all to be able to show a direct relationship between cause and effect. Such is not possible in this study for too many forces are at work which cannot be measured at this time. The fact that the council engaged in or initiated a certain activity can be mentioned and sometimes a subsequent change in the community may be called attention to, but this is not intended as a definite 
statement that the councils were solely responsible for this change. The Health Council has been mentioned in the formation of the social planning program of the community Chest, but further discussion of the activities of the Health Council provide another area of study.

The Articles of Agreement of the Councils stated In definite terms what their objects should be. AccordingIy the Recreation Council was set up to do the following things :

(1) To make a continuous inventory of the recreational and character building facilities in Louisville

(2) To serve as a planning promotional medium for existing agencies and to encourage the establishment of additional or new facilities where necessary.

At the first meeting of the Executive Committee of the council three standing committees we apoolnted: the Permanent Survey Committee, the Training Committee, and the Publicity and Progress Committee. The outstanding project for the council was the self-survey which covered the private recreation agencies including the churches, orphanages, recreation in the home, and facilities for recreation in various industries. No attempt was made to touch upon commercial recreation. After the completion of

${ }^{1}$ Articles of Agreement of Recreational Division, Article I, Section 1, June, 1924.

$2_{\text {Minutes, }}$ Executive Committee of the Recreation Counc11, June 17, 1924 . 
the collection of the data, Mr.F.E. R. Miller of the American Playground and Recreation Association sumnarized the statistics, wrote the report and made recommendations.

It was stated in these recommendations that a more extensive use of the school recreation facilities be made, that the luncheon clubs turn over to the city the playgrounds they had established, in order to open new playgrounds in unserved areas, and most important, that a superintendent of recreation be employed by the city to take charge of a city wide recreation program.

The Recreation Training Courge which was held for six meeks in February and March of 1925 has been mentioned above in relation to the budget of the council.

The Summer Camp Committee, which was appointed as a coordinating medium for those agencies conducting camps and those sending cllents to camps, organized a Sumner Camp Counc11. This group conducted a study of camping facilities and made rocommendations as to their increased use, compiled a Directory of Sumer Camps in the Louisvilie area, and cooperated with the Louisville Times in its Fresh-Air Fund Campalgn to send children to homes in the

${ }^{1}$ Ib1d., March 23, 1925.

$2_{\text {Minutes, }}$ Recreation Council, November 1, 1925.

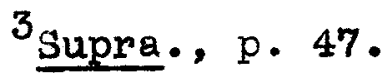


country for vacations. Another activity of the Recreation Council was sending special speakers to various organizations.

By March, 1926, the Council was functioning through six standing committees which were in addition to the three original ones: The Sumer Camp Committee, Membership Committee and the Orphanage Comnitter. A Placement Bureau was set up to fill requests for recreation workers in and out of Louisvilie. Two joint surveys with the other two Councils were also conducted in 1926; they were the survey of cond1tions on the Point, and the study of the East End Day Nursery.

During 1927, the Council's main projects consisted of the following: Volunteers' Bureau conducted to furnish tralned volunteer group leaders to recreation agencles and children's Institutions; Play Days sponsored in eight of the orphanages; short time demonstrations conducted to show the value of a recreation program in a given institution. The work of the Recreation Council declined when Miss Levin resigned in June, 1927. At the time of her resignation she recommended that the Volunteers' Bureau be enlarged, that the orphanage work be continued, that the recreation institutes be continued, that more research be done and that a regular Speakers' Bureau be formed. '

\footnotetext{
${ }^{1}$ Minutes, Executive Comnittee, Recreation Council, June 24, 1927.
} 
During the period of a year when the Council was without a secretary, the council decided to continue with the established activities and to wait until a secretary was obtalned to initiate any new projects.

The Case Work Council (or the Family and Child

Welfare Council as we shall refer to it hereafter) was guided in its program by the broad definitions of 1 ts function that were given in its Articles of Agreement. Accordingly the objects of the Council were:

To make a continuous study of the inter-relation and function of agencies in this council and other related activities.

- To serve as a cooperative and planning medium for member agencles and other related activities.

To develop new and improve present facilities and standards of service through joint study of social problems. 1

The first meetings of the council were devoted to establishing it on a working basis. On May 1, 1925, three comittees were appointed to begin the work of the council. A Children's Committee, an Illegitimacy Committee, and a Committee on the Feebleminded were formed and temporary Chairmen were appointed to call together the agencies interested in the work of such committees. At a later

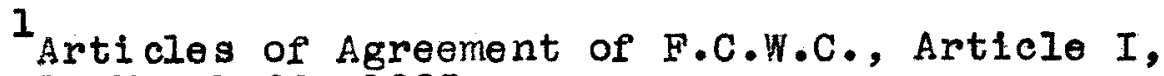
Section 1, March 26, 1925 .

$2_{\text {Minutes }}$ of the Case Work Counc1l, May 1, 1925. 
meeting in discussing the election of permanent chairmen for these committees it was decided that such a person might be chosen from the professional group or from the community at large.

The only committee that was active prior to 1926 was the Illegitimacy Committee. They initiated a small study to determine the extent of this particular problem in Louisville. Since the Council lacked effective organization due principally to the absence of a pald executive this project failed to materialize. In 1926, there was a revival of activity which was sustained until a permanent paid executive was acquired. A temporary community program for urmarried mothers was inftiated by the Illegitimacy Committee in April, 1926. Under this program it was agreed that every agency or individual in the community would refer to the Children's Protective Association any unmarried mother, any girl with an illegitimate child "irrespective of color, age, or creed." The agencies concerned limited their functions to certain specific areas of the problem and the Caildren's Protective Association referred the girls to the proper agency after giving them case work service. At the end of the six months' trial period the Illegitimacy Committee reported that the program had meant closer coopera${ }^{1}$ Ibid., November 5, 1925. 
tion and better understanding of the situation of each agency handling this problem.

Early in 1926, the Executive Comittee of the Community Chest reported the unsatisfactory conditions of a small orphanage in the chest. Since this was the first request of this kind the council considered these questions :

1. Was the matter one in which the council should act?

2. Could the councli act in any effective manrer? 2

3. Should the Council establish a defintte policy?

The Health Council and the Children's Bureau were also concerned since the health standards were known to be low and the Children's Bureau had been first requested by the orphanage board to make-the study. It was decided that the study should be made by a joint committee of the Health and Family and Child Welfare Councils. The final report of the situation was presented to the Executive Committee of the Family and Child Welfare Council and it was declded to regard it as confidential. 3 The survey committee did not theoreticaliy make any recommendations

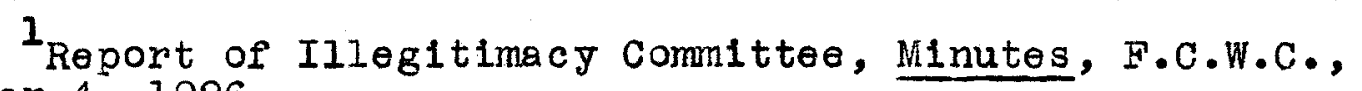
November 4, 1926. 1926.

Minutes, Executive Comittee, F.C.W.C., January 1, ${ }^{3}$ Ibid., May $12,1926$. 
for the ones appended to the end of the report were the Children's Bureau's.

The Health Council and the Family and Child Welfare Council cooperated in considering the matter of the case work and pre-natal care given at the Susan Speed Davis Home, and cooperated in the study of facilities for the chronically ill. In December, 1926, an advisory committee was appointed to act with the adjutant of the Susan speed 1

Davis Home.

The Advisory Council of the Community Chest referred the problem of street begging to the Family and Child 'Welfere Council. A committee appointed from the council visited the Mayor and offered the assistance of the Council in making investigations and plans for the beggars on the street.

The members of the council felt that there was a need for an employment bureau but believed that it should not be established until a study was made of the situation. The Counc1l prepared a questionnaire and sent it to all social agencies that came in contact with the problem. The agencies were asked if they felt such a bureau would

\footnotetext{
$1_{\text {Minutes, }}$ F.C.W.C., December 8, 1926. 1926.

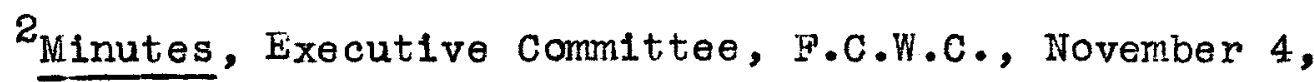


be a social asset and if they could contribute funds. The agencies indicated their desire for such assistance, but the Community Chest lacked funds to undertake any new work. The comnittee considered other sources of support but no further action was taken at this time. The Children's Committee was not active during the period from 1925-1927 dolng only a little work along educational lines in relation to the problem of child 2 labor.

The council endorsed the recommendation of the Louisville and Jeffers on County ChIldren's Home to have abolished the position of Superintendent of the Board of Children's Guardians in the Police Court since this work was handled in the Juvenile Court.

A Research Committee was appointed as a special conmittee. It served to secure information from the records of the agencles regarding illegitimacy, feeblemindedness, and other causes of family disintegration. Mrs. Halleck in her Annual Report to the Council stated that this committee was thorough as far as it went, but

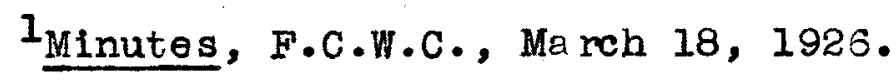

Zinutes, Children's Committee, F.C.W.C., June 22, 1927. 1926.

3 Minutes, Execut1ve Committee, F.C.W.C., December 29,
} 
its findings remained too incomplete to serve as adequate 1 data upon which to base any conclusions.

The Council had been given a small budget of two hundred dollars for 1927, and only nine dollars had been spent. It was suggested that the balance not used by the council be used for publicity in securing the passage of the Mother's Aid Bill. The sum of one hundred and fifty dollars was voted to be appropriated for this cause.

After working along for two years some changes were made in the council. It was found that the complttes on Illegitimacy and children could be combined under one Chalrman. The attention given to street begging resulted in the realization of the need for better work with transients and a temporary committee was appointed to work out a definite program for their care.

It is noticeable that much of the work of the Council consisted of surveys. In 1926, the Counc1l made a few and in 1927 the Budget Committee of the Community Chest requested others. The Executive Committee of the Council discussed whether the council should undertake

\section{${ }^{1}$ Chairman's Report, Annual Meeting, F.C.W.C.,} March 29, 1927.

2 Minutes, F.C.W.C., November 23, 1927.

3 Ib1d. 
any more surveys or studies of member organizations. Early in 1927, a communication was sent to the Executive Committee of the Chest advising them against such surveys by the council since they might be interpreted as criticisms and lead to misunderstandings. They recommended as a substitute that the whole commity be studied, then those organizations supplying the special community need should ascertain for themselves whether they were fulfilling their obligation.

The activities of the Family and Child Welfare Council have been discussed in greater detall because policies that affected future activities of the Councli of Social Agencies were involved. This may be rather misleading as to the actual accomplishment of the council and it should be pointed out that the work of the Council was handicapped by. the lack of a permanent pald executive. It cannot be said definitely that the Family and child Welfare counc1l could have accomplished as much as the Health Council did in its early years because there are many factors in operation for which there is no measurement, but it is possible that a permanent executive would have assisted the Council in getting an earlier start and 
in clarifying its purpose and scope of activity. The time had now come when the councils could concentrate their efforts on securing the best social and health services for the community.

Surmary

From the time of the formation of the Community Chest in 1924, the social planning activities in Louisville have been performed by three groups: the Recreation Counc1l, the Health Council, and the Family and Child Welfare Counc11. At first no constitutional provision was made for the councils by the Community Chest but they were organized as a part of the Advisory Council, a group intended to coordinate the social planning activities of the counclis which did not function actively. With the revision of the chest constitution in 1926, the three councils were designated as sub-councils of the chest and the coordination function of the Advisory Council was delegated to a newly formed Social Planning committee. This group did not materialize and remained inactive.

The Health Council began in 1925 with a budget and a paid executive but the Recreation and Family and Child Welfare Council did not receive the services of a full time executive until January 1, 1926 and April 1, 1928 respectively. This was due to several factors: the 
Health Council's appeal was more dramatic and came after the wave of enthusiasm related to the Emerson Health Survey; the Chest was unsuccessful in its campaigns and funds were not available; there were personal conflicts within between the executives and board members of various agencies; the Chest was considering the reorganization which eventually took place; and it was still not clear to the public why such groups as Counclis were necessary due to the intangible nature of their work.

During the first months of their existence most of the work of the councils was related to setting up the organization, appointing committees, defining purposes and scope, and gaining a preliminary knowledge of the situation in each particular area of service in the community. Numerous surveys and studies were made by all three councils during this time and some results were seen in the conmunity. The councils cooperated on several studies relating to the orphanages and nursery schools. The development of staffs was encouraged by the councils through institutes and bringing outstanding speakers in the field of social work to the community. In addition, the lay-members who acted as delegates to the councils and served on committees were given an opportunity to learn more of the social and health problems and facilities in their community. 
The councils were so busy finding themselves that they had little opportunity to do any long-range social planning, but they did succeed in working out better cooperation between agencies and coordination of work that had not been possible before. 


\section{CHAPIER V}

THE FANILY AND CHIDD WELFARE COUNCIL AND IHE RECREATION COUNCIL, 1928-1934 


\section{CHAPTER V}

THE FAMILY AND CHILD WELFARE COUNCIL AND THE RECREATION COUNCII, 1928-1934

The years from 1928 through 1934 proved diverse as far as national and world affairs were concerned, for the country reached the helghts of prosperity. Within the same period it also sank to the depths of depression. In 1928, the Louisville City Government Bill was passed which provided for the establishment of a Department of Welfare in Louisville. Under the bill the Department was given broad powers in the field of welfare. In accordance with this act, the Department of Public Welfare was organized in Louisville in January, 1930. Unemployment was increasing and there were more demands for relief, but the situation was regarded as temporary in nature and no permanent program to meet the needs was planned. The city appropriated money to the Family Service Organization to distribute to those needing relief. In November, 1930, the Unemployment Rellef Bureau was formed to provide three days of work relief each week during the winter months. No work relief was given during the summer but the clients were helped by the Family Service Organization. The name of the Unemployment Relief Bureau was changed to the 
Municipal Relief Bureau and in 1934 its functions were expanded to provide service for the Home of the Aged, the permanently handicapped, and to care for the homeless residents.

The public Recreation Department was removed from under the direction of the Board of Park Commissioners and became a division of the Department of Welfare. Since the public recreation program was carried out chiefly in the parks responsibility was divided between the two agencles. Miss Elizabeth Wilson explains this relationship in her study of recreation in Louisville.

The United States Government organized the Federal Transient Bureau in 1933 which established shelters and provided work for transients.

Such factors would definitely affect the development and work of any organization. When people are starving, an organization such as a council of social agencies or a recreation council has to prove its worth to the community. Intangible things are always difficult for the publ1c to understand, and cause and effect are not always noticeable over a short period of time, if ever.

${ }^{1}$ Courler-Journal, October 7, 1934 .

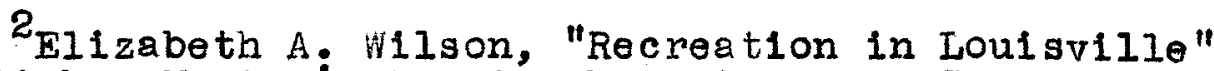
(Unpublished Master's Thesis, Department of Sociology, University of Loulsville, 1938), p. 96. 
On May 1, 1928, for the first time, the Recreation Council and the Family and Child Welfare Council were functioning with full time pald executives when Miss Levin returned to the Recreation Councll and the offices of the Family and Child Welfare Council were opened with Mrs. Loulse $R$. Wood as secretary. Because of the unsettled conditions of the Community Chest Mrs. Wood was appointed temporarliy but a few months later she was employed on a permanent basis.

According to the Constitution of the Community Chest, the Councils were created under the Social Planning Comittee, but since this comittee did not function, the Councils came under the Central Council or the Board of Directors of the chest. The exchange of representation between the councils and Chest was continued with the Executive Secretary of both Councils serving on the Executive Committee of the Chest, and the secretary of the chest as a member of the Executive Comnlttee of the Councils. Miss Levin stayed with the Recreation Council until September 13, 1929, when she resigned to accept another position, and Miss Emily Reed was appointed as her successor. Although the Community Chest was successful in the 1928 Campaign for the first time in several years, the success was not continuous. Agency demands for funds were 
increasing and each year the Recreation Councll was faced with a budget reduction. In 1932 and 1933 the agencies in Loulsville were swamped with requests for ald and at the same time their budgets were curtailed. Under such circumstances Miss Reed submitted her resignation on March 10, 1933. Her feeling at this time was that the recreation agencies were so burdened with adjusting and maintaining their own program that they had little time or energy for cooperating on new projects. The council asked Miss Reed to remain until June 1 to complete a few profects with the hope that by that time nore definite plans could be made. The Articles of Agreement of the Recreation Council were revised in 1930 to increase the size of its Executive Comnittee.

It seems that one of the outstanding functions of the Recreation Council was to make Louisville recreation consclous, and in this connection the Council was most active in giving talks to parent-teacher groups, churches, civic groups, and others interested in the

$1_{\text {Minutes, }}$ Executive Committee, Recreation Council, Miarch $10, \overline{1933 .}$

$2_{\text {Ib1d. }}$

${ }^{3}$ Ibid., April 5, 1933

${ }^{4}$ Articles of Agreement, Recreation Council, Article VI, Section I, May 29, 1930 . 
subject. It is interesting to note that after the Recreation Council had been functioning for a few years, the Board of Park Commissioners organized a Department of Public Recreation, and a recreation program was established in the parochial schools. Great interest was stimulated and the training courses offered for both professional and nonprofessional group leaders were very popular. During the period, 1928-1934, the Council continued to conduct institutes to meet the needs of particular groups such as the Church Recreation Institute, the institute for volunteer workers in social organizations, institutes for colored leaders, institutes for playground leaders with which the Council assisted the Board of Park Commissioners, training in leadership for the Daily Vacation Bible School teachers; and institutes for training camp counselors who were employed in the sumer camps.

Continuing its policy of coordinating the recreational activities in Louisville in an attempt to help the agencles plan jointly a community wide program, the Recreation council encouraged the organization of the Federation of Settlements, conducted conferences of boards and directors

'courier-Journal, May. 20, 1928.

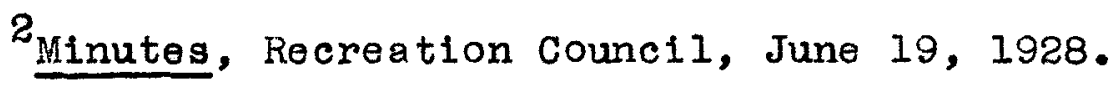

3 Minutes, Annual Meeting, Recreation Council, January 28, 1929; Minutes, Recreation Council, May 28, 1930. 
of sumer camps, and brought together directors of public and private recreation agencies so that the problems facing both would be understood. As a result of a study made in 1928 of cinlidren's needs in Louisville at the request of the Kiwanis club it was found that one of the lacks was the absence of supervised recreation in the orphanages. To meet this need the Recreation Council conducted playdays in six orphanages to demonstrate how recreation could be used there to an advantage.

During the latter part of 1932 , the Recreation Council worked out a plan with the Public Depertment of Recreation to send leaders to institutions to demonstrate the advantages of a planned recreation program, but only five institutions accepted the of for. An institute for colored volunteers and the course for the Junior League Provisional members were given by the council.

During 1931 the Recreation Council initiated a delinquency study in an effort to learn pre-delinquency characteristics in children. The Family and Child Welfare Council also participated in the study. Eventually it was realized that delinquency resulted from so many interacting

\footnotetext{
${ }^{1}$ Infra., p. 93.

2 Minutes, Executive Committee, Recreation Council, october II, 1932.
} 
kinds of poor child welfare that only by continued cooperative effort could any causes or sugeested plans for prevention be studied.

However, the special emphasis of the Recreation Council during 1931 and 1932 was on the presence of young people and adults who were out of work and without money for recreation. The council realized that this was a difflcult group to reach because they were discouraged and withdrawn. Special efforts were made to serve them, and the agencies which were most successful in meeting the need appear to have been those connected with the Unemployment Bureau or those that offered other possible ways by which the unemployed could help themselves or learn new jobs. One of the projects used frequently was the reading, game, and handwork room over the Unemployment Bureau for the adult unempioyed.

Although the secretary of the Recreation Council had planned to leave in March, 1933, she consented to stay until June 1, 1933. During these few months the Recreation Council was helping with the Jefferson County white House Conference, surveying adult leisure time, and carrying on

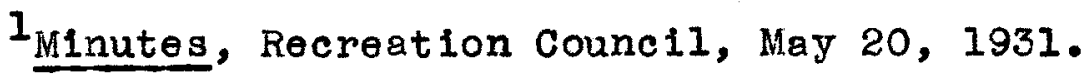

2 Ibid., January 23,1932 . 
1

the work of the Camp clearing Committee. The last annual meeting of this Council was held in May, 1933, and the activity of the council ceased.

It has been mentioned that the Family and Child Welfare Council acquired an executive in 1928 , but it also experienced another period of being without a full time executive when in August, 1933, the Munlcipal Relief Bureau was left without an executive and Mrs. Wood assumed the duties of that position. She remained with the Bureau until March, 1934, when she returned to the Council. During the period when the council was without an executive a decline in the work was apparent.

The Articles of the Family and Child Welfare Council were amended in April, 1930, to include the members of all the comnittees as members of the council and to increase the appointments to the Executive Committee from three to five.

Agency membership in the Family and Child Welfare Council was considered during this period, and the secretary

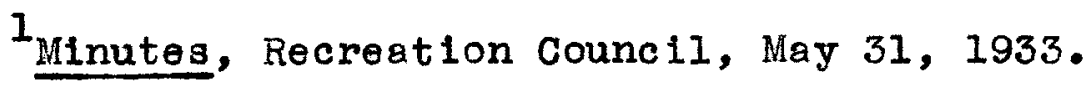

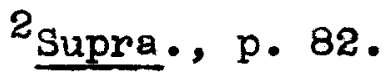

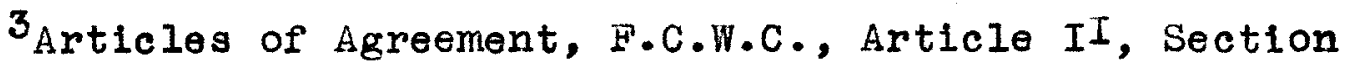
3, April 1, 1930.

${ }^{4}$ Ibid., Article VI, Section 1. 
gave "interested participation" as her interpretation of eligibility for membership in the council. The question of interesting public agencies in the work of the council was also ralsed. The composition of the Executive Committee of the Family and Child Welfare Council was discussed, and it was felt that technical experts were necessary for the direction of the Councll because of the nature of the problems presented to the committee, 3 and that the public should be largely represented on the comnittees. The Family and Child Welfare council conducted its work on a committee basis. Both standing committees and special committees were used, and at length it became necessary to clarify the difference between the uses of the two types. It was agreed that."a standing committee is ready to recelve suggestions for new projects related to a particular sphere," while the special committee "is formed to accomplish a definite piece of work and may be revived whenever necessary. 1930.

${ }^{1}$ Secretary's Report, Minutes, F.C.W.C., October 6 ,

2 Minutes, Annual Meeting, F.C.W.C., March 1, 1929.

3 Ibid.

4 Minutes, Executive Comittee, F.C.W.C., March 12, 1930. 
All comittees with the exception of the interagency committee were composed of both lay and professional members. The community members were selected by the committee chairman with the assistance of the executive secretary and they were men and women who had indicated same interest in the social conditions in Louisville.

During the years 1928-1934 the Family and Child Welfare Councll interpreted 1ts function as follows:

The true function of this planring body is to coordinate the agency members, to adjust and harmonize, to simplify the work, to effect economy of money and time and to make the social services touching family and child life more and more efficient.

During 1928 the majority of the activities of the Counc1l were conducted by committees on Transients, Children, Employment, Relief, Day Nursery, Illegltimacy, and Research. The Transient Committee was formed on January 3 , 1928, to study the transient problem in Louisvilie, and to prevent duplication of effort. It was composed of many of the organizations that came in contact with transients, and in time it hoped to have representation from all of them. The group met monthly and the member organizations reported on the number of transients cared for, on the

$1_{\text {Minutes, }}$ F.C.W.C., March 1, 1929.

$2_{\text {Minutes, }}$ Transient Comnittee, F.C.W.C. (Filed with Minutes F.C.W.C.) January $1,1928$. 
use of the Social Service Exchange, and on housing and transportation. Out of this study three things were learned:

1) The problem is large

2) There is duplication of effort

3) The public is frequentiy induced to take up collections for transients because the transient claimed he was sent from 'piliar to post'l

Sub-committees were formed to deal with specific aspects of the problem such as homeless men, vagrants, and beggars. The Committee on Begging called to the attention of the Mayor and the Chalrman of the Board of Public Safety the number of peggars on the streets, and assurance was given that the police department would cooperate with the Council. Efforts were also made to educate the public In regard to the harm caused by contributing to beggars by showing that in most cases the beggars had other incomes or preferred begging to a job or Inadequate relief. Many were dope addicts and alcoholics. The Committee on Homeless Men sponsored an active campaign to provide better accomodation for translent men and succeeded in improving housing conditions for them.

Gradually the work of the Transient Committee brought together as committee members nineteen agencies. Th1s group worked out plans for a iransient Service Bureau

1 Minutes, F.C.W.C., March 27, 1928.

2 Ib1d. 
as a three months experiment with the Traveler's Ald at the Union Station to provide a thorough interview with all nonresidents within Louisvilie one week or less, to register and clear with the Social Service Exchange, and to refer cllents to the proper agency for treatment. In october, after the three months trial period, the Executive Committee of the Family and Child Welfare Council voted to continue the centralization of the responsibility for all transients with the Traveler's Aid Society. As a result of working with this problem of transients the committeo felt the need for a residence law in Kentucky and pesented 1t to the Executive comittee of the counc1l and it was declded that the State Conference of Soclal Work would be asked to appoint a special committee to sponsor such a 1aw. It is interesting to note that in 1929 the Cormittee reconsidered its statement of the need for a residence law in Kentucky and it felt that more careful consideration was necessary. 'lhis change in thought was reflected later when the Transient Committee decided a more positive attit ude tow ard the care of people should be taken instead of the negative one produced by a residence law which

\section{$1_{\text {Ibld., July 3, } 1928 .}$}

$2_{\text {Minutes, Executive Committee, F.C.W.C. (Filed }}$ with Council Minutes, December 10, 1943.) 
shifts the responsibility for those in need of assis tance 1 from one unit to another. The Transient Comittee continued to expand its transient program achieveing a centralim zation of responsibility for the care of the transient without apparently realizing that very little was being done to meet the problem of why the people were transients. The committee's interest lay in protecting the community which resulted in less care for the transients.

Early in 1933, a national census was taken of transients for three days and the local committee agreed to undertake it in Louisville. However, in 1934, the United States Government established a Federal Transient Bureau on a national basis and in the process the Louisville program was abolished. The Federal program was called a casework program, and the men were interviewed and sent to shelters for lodging. The shelters did not limit the number of nights' care, but it was the plan to send the man back home if possible. If he had no residence he was put to work. Whe intake problem was so involved that it was referred to the Council's Inter-Agency Comittee for 3 recommendations. 1931.

${ }_{\text {Minutes, }}$ Transi ent Comitte日, F.C.W.C., April 13, 2 Ibid., April 19, 1934

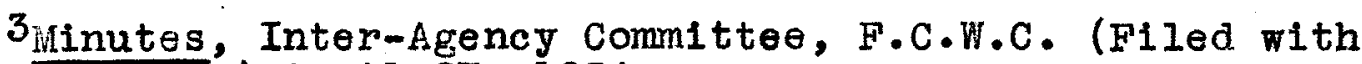
F.C.W.C. Minutes) April 27, 1934. 
The Klwanis Club of Loulsville requested in 1928 that the Family and Child Welfare Council make an investigation of children's needs and what was being done to meet those needs. After study, the following children's needs were found to exist in the community:

Inspection and licensing of commercial boarding homes for children

Lack of supervised recreation in orphanages

Unlicensed children in street trades

Special camp for problem children

Need for educating public opinion and police in regard to begging children

Need for trained leaders in social work

Need of educating parents of employed children in dangers involving their children

Necessity of summer round-up of pre-school children Establishment of a Vocational Guidance Bureau

The result of this study was far reaching, for the work of the three Councils in this area centered around developing communty resources to meet these needs during the six subsequent years.

An effort was made to give the police a greater understanding of social service activities in the community through talks given by agency executives and paragraphs describing activites of Chest agencies published in the

\footnotetext{
$1_{\text {Minutes, Children's Committee, F.C.W.C., (Filed }}$ with minutes of F.C.W.C.) May 16, 1943. 1928.

2 Minutes, Children's Comittee, F.C.W.C., June 13,
} 
1

Police Bulletin. A special comitteo was appointed to study, draft, and present for passage an ordinance providing for the licensing and inspection of boarding homes for children and day nurseries. This law was passed in January, 1929, and placed the responsibility for enforcement on the City Health Department because the Department of Welfare did not exist at that time. The Children's Committee looking toward the time when it might be possible to secure a State statute for the inspection of boarding homes for children, recelved the sanction of the Executive Committee to include state and County officials on the Boarding Home Committee of the Health Department.

Work with children employed in street trades and begging children was begun, but uninformed public opinion was in sympathy with the working chlldren and the task of the comittee centered around educating the public about the dangers involved. The newspapers were not very cooperative for they felt they were giving the boys an opportunity to help their needy families. Plans were formulated and carried out to make home visits to families of underage children in street trades and to work with 1928.

IMinutes, Executive Committee, F.C.W.C., July 24, Ibid., May 8, 1931. 
the families on this problem. The Juvenile Court agreed to do this work since no other agency had the authority to do 1

1t. It was found after discussions with the Board of Education that the organization of a vocational guidance bureau would duplicate the vocational programs in the schools.

The Travelers' Ald Board requested the Councli to call a meeting of representatives of the Children's Bureau, the Children's Protective Association, Psychological Clinic, and Travelers' Ald to confer on the question of including separate rellef items in their respective bud3

gets. These agencles recelved funds from the Family Service Organization for extraordinary relief since the amount for such 1 tems had been included in the Family Service. Organization budget. This committee felt that in the interests of good casework techniciue that each agency should have the facilities for doing a complete casework job in its particular fleld which in some instances required a minor expenditure of money. After meeting four times the committee recommended to the Budget Committee

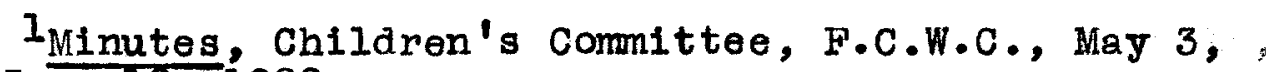
1929, June 19, i929.

${ }^{2}$ Ibid., June 13, 1928.

3 Minutes, Relief Committee, F.C.W.C. (Filed with F.C.W.C. TInutes), September 20, i928. 
that each agency be allowed a small amount in 1 ts budget for special rellef. Seven hundred and fifty dollars formerly allowed in the Family Service Organization budget for these agencies to draw on was apportioned to the individual agencies in the budgets for 1929. In accordance with this recommendation the agencies met and agreed on the amount each should have. After the plan was in operation for a year it was decided to continue it on an experimental basis through 1930 .

The Illegitimacy Committee was reorganized under the Children's Committee and during 1928 its main work was discussion of casework policies and techniques in handling specific cases. A Susan Speed Davis Home Coordinating Cormittee was formed but was not used. After studying the problem of illegitimacy for five months, the following outstanding needs of the community in the care of unmarried mothers were noted: care

1) Foster homes wherein child and mother may have

2) Some provision for the care of colored mothers and babies

3) A protective agency for girls over twenty-one years old

4) A concentration of the work in making two or three agencies responsible in order to avold duplicam tion 3

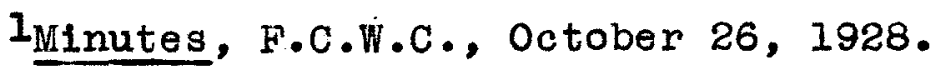

$2_{\text {Ibld., January 1, } 1929 .}$

${ }^{3}$ Ibid., March 1, 1929. 
It was not until the following year that an attempt was made to meet these needs. Beginming in February, 1929, the Illegitimacy committee began asking the agencies to keep track of their illegitimacy cases. After only a few months the committee realized that although the health problem was primary, case work was an outstanding need throughout. The Susan Speed Davis Home welcomed the Committee's suggestion that their girls be studied. The Psychological clinic cooperated by giving the psychological examinations, and the adjutant said she hoped that such testing would soon become part of the regular admitting procedure. After discussions with the City Hospital Soclal Service Department, Family Service Organization, and the Children's Bureau, the Committee declded that there was no question of the need of some form of centralized casework with unmarried mothers, and it was proposed that a caseworker be added to the staff of the Susan Speed Davis Home as a demonstration. 'The Executive Committee of the Family and Child Welfare Council approved the Illegltimacy Committee's recommendation. 3 This resulted in a request to the chest

\footnotetext{
$1_{\text {Minutes, Illegitimacy Committee, F.C.W.C., (Filed }}$ with F.C.W.C. Minutes) May 6, 1929.

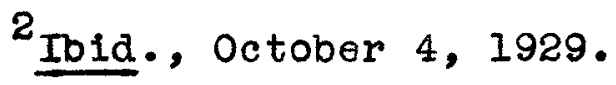
1929.

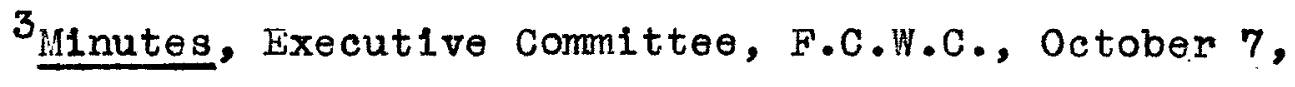


Budget Cormittee which was granted provided the campaign goal was reached. 1

The problem of illegitimacy was complicated at this time by the growing relief need and resulted in changing the division of responsibility for unmarried mothers. A sub-committee studied the situation and worked out with the Family Service Organization and the Children's Agency definitions of the various types of unmarried mother cases and recommended plans for their handling. The committeo again informed the Budget Committee of the Chest of the need of a permanent social worker at the Susan Speed Davis Home.

The Research Committee of the Council was revived in 1928 when the council agreed to participate in the Registration of Social Statistics sponsored by the University of Chicago. The Health and Recreation Councils also participated in collecting the data. This work made It necessary for the secretary of the Family and child Welfare Council to visit the orphanages and a cooperative relationship seems to have been established. The

IIb1d., December $18,1929$. 15, 1932 .

2Minutes, Illegitimacy Committee, F.C.W.C., November

${ }^{3}$ Ibid., October 24, 1932. 
Executive Committee was concerned with how social questions coming to it should be met, and it was declded that these projects should be presented to the Council Research Committee which would consider whether the study were necessary. The Research Comittee could also inltiate studies. In order to make the Research Committee of the Council fit into a community plan of research it was felt that a full time social statistician was necessary. The Federal Children's Bureau assumed the collection of social statistics that the University of Chicago had begun and the Research Comnittees of the Councils continued their participation in collecting the data. The Research Comittee of the Family and Child Welfare Council made plans to use the Louisville statistics to show the development of the social agencles over a given period and to compare them with similar agencies in other cities. In 1939, the Council of Social Agencies cooperated with the Health Council in the collection of data for the United States Children's Bureau which for the first time resulted in the social agencies and organizations in Louisville being able to compare the total expenditures on health and welfare in Louisville with per capita expenditures in other cities 1931.

${ }^{1_{\text {Minutes, }}}$ Executive Committee, F.C.W.C., December 10, 
of like size.

In 1928, a complete day nursery survey was undertaken by a joint committee of the three councils at the request of the directors of the Community Chest. The Health and Recreation Councils formulated plans for the nursery plant and staff and a schedule of activities. Standards for health and recreation were also set. As a result of the survey it was also recommended that case work methods be used with each family applying to the nursery in order that family responsibility might be strengthened and the children kept at home wherever possible. A Day Nursery Committee พas appointed in the latter pert of 1929 at the request of the East End Day Nursery to discuss the responsibility of the nursery to the family using the nursery. After a series of discussions on the part of representatives from eight caseworking agencies and day nurserles it was decided that there was need for social investigation of cases admitted to the East End Day Nursery and that there was a problem of supervision of the children over nursery age whose parents were employed. Plans were worked out with

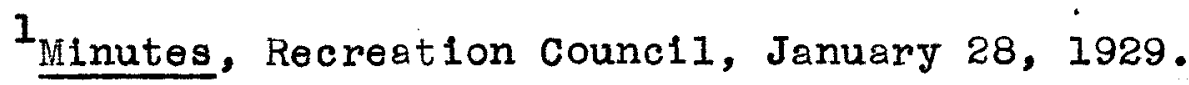

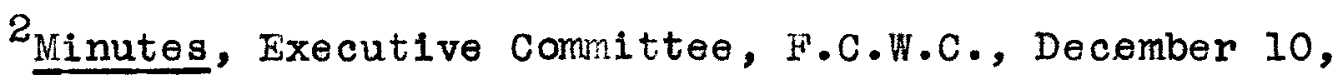
1928.

3 Minutes, Executive Comittee, October $27,1929$.

$4_{\text {Minutes }}$, F.C.W.C., October 6, 1930.
} 
community agencies to meet these needs. The Children's Bureau made investigations of applications for admission for a three month period and the Nursery wished the Children's Bureau to continue these but the agency's own demands were so great it could not do so. After a brief study of the extent of lack of supervision for children, arrangements were made with the Recreation Council to interest the settlements in the problem of making some provision for these chlldren.

-In addition to the studies of the Susan Speed Davis 3 home, the East End Day Nursery, and rellef, the Research Committee conducted studies of the Colored Orphan's Home, Iegal Aid Society, Jewish Children's Home, and the Union Gospel Mission Girl's Boarding Home. The Commlttee recommended that the Colored Orphan's Home, the Jewish Children's Home, and the Union Gospel Mission Girl's Boarding Home be discontinued as such since their services were already provided on a larger scale or more efficiently by another group in the community. Both the colored group and the Unton Gospel Mission were reluctant to withdraw their 1930.

IMinutes, Executive Comitteo, F.C.W.C., September 26,

2 Minutes, F. C. W. C., March 6, 1931.

$3_{\text {Supra., p. } 97 .}$ 
services but since the recommendation went to the chest budget committee they had little choice. It was recommended that Legal Aid have more adequate office space and clerical staff and that they make use of the facilities of the Social Service Exchange.

One of the most time consuining activites of the Council that began in 1931 and continued for several years was the problem prosented by the Volunteers of America. Surveys were made of this group's work and its methods and since the reports were considered confidential it may be said that the program they proposed and started was a duplication of work already in existence in the community. However, the council lacked authority to demand cessation of their activity.

During 1932, the council became conscious of the need for the agencies to give publicity to their work to educate the community regarding the functions of the various agencies. The Research Committee suggested that more use be made of the statistics collected for the Chlldren's Bureau and offered to prepare them for public distribution. The Council at various times during this pe riod became interested in bills before the State Legislature 28, 1932. lilnutes, Executive Committee, F.C.W.C., February 
such as Mother's Aid, child labor, and the Model Loan Shark Law. One Council meeting during 1931 was devoted to a dis cussion of soclal legislation which would be presented at the next Legislature.

In December, 1928, when the proposed C1ty Government Bill came up, there was discussion of whether a Department of Public Welfare would be formed. When it was definite that a Department of Public Welfare was to be formed the Mayor was approached by a member of the Executive Committee of the council to ask his consideration of the appointment of an advisory comittee of five who would help him in planning a department of public welfare. The Mayor stated that it was useless to consider the question of the Department's giving relief because of the lack of funds. After having discussed the provisions for this department with the City Attomey who was of the opinion that the city legally could undertake social work, the council considered what kind of social program it would like the City department to 3 initiate. Paul Benjamin, in an address before the League of Women Voters, stated that such functions as work with

\footnotetext{
IMinutes, F.C.W.C., October 14, 1931.

$2_{\text {Minutes, }}$ Executive Comittee, F.C.W.C., January 29, 1929.

3 Minutes, F.C.W.C., March 1, 1929.
} 
aged, the chronically 1ll, the unemployed and investigations for the Home of the Aged and Infirm be transferred from private agencies to the public agency.

The council had been interested in the establishment of an employment bureau since 1928. The private agencies had been unsuccessful in obtaining a source of support for an employment bureau so the Family and Child Welfare Council turned to the Department of Public Welfare in December, 1929, with the hope that the Director would favor the development of such a bureau in his department.

Plans were made for the establishment of a federal, state, and city employment agency in June, 1932, and the Family and Child Welfare Council endorsed the Louisville Public Welfare Director's work to effect this combination. In the latter part of 1928 and early 1929, the Family and Child Welfare Council and the Health Council became interested in the care available for chronics and cancer cases. After taking the matter up with the Director of Health the Mayor appointed a committee through whom all cases of this kind would be cleared. 5

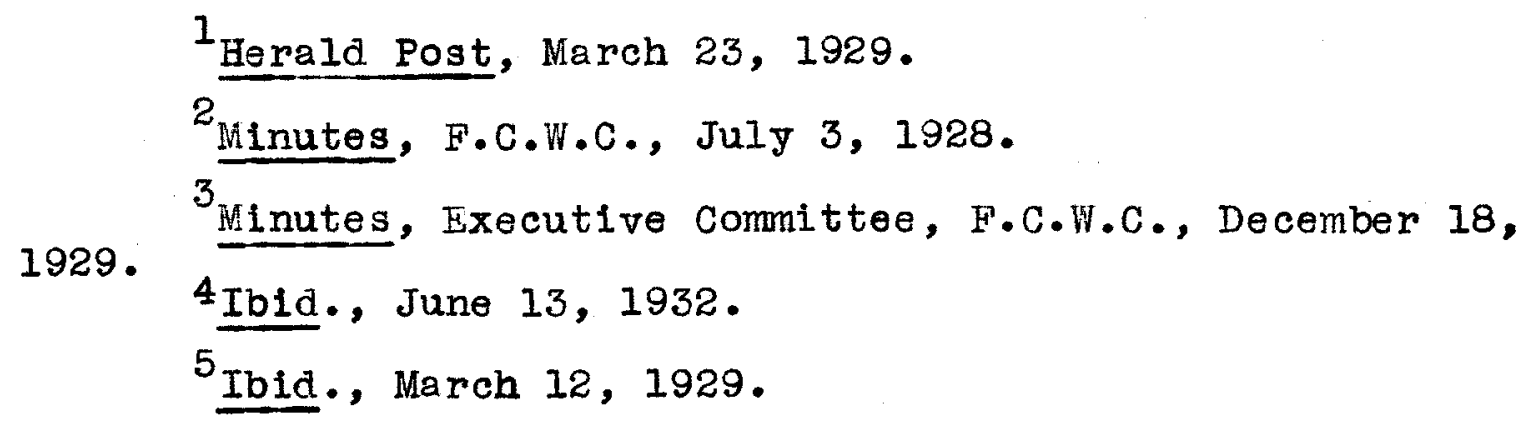

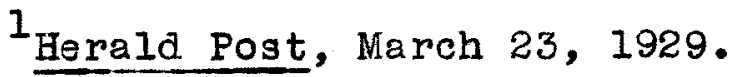

$2_{\text {Minutes, F.C.W.C., JuIy 3, } 1928 .}$

3 Minutes, Executive Committee, F.C.W.C., December 18, 1929.

${ }^{4}$ Ibld., June 13, 1932 .

5 Ibid., March 12, 1929. 
During 1929, it seems as if the public departments, including health, welfare, recreation, court, and pollce, were being considered more and more a part of the whole social plan. In 1930 as the momentum of depression began to gather this trend increased.

The impact of the increased demand for relief was felt early in 1930 and all agencies felt that stafes and funds were inadequate to meet the problem. Beginning in February a series of meotings were held throughout the year to consider the wisest way to spend the money available in order that each organization would know the limftations of itg work. To halt public criticism of the agencles publicity regarding the lack of funds to meet the needs was given. Cooperation and understanding among the agencles themselves was urged since it was realized that all the agencies were so intimately tied together and no longer could the problems of soclety be isolated into categories. The council became very concerned with the relationship between public and private relief and the division of responsiblilty and it was the foeling of the councll that the public agencies should be expanded to handle the rellef cases on sand casework principles and thus limit the intake of private agencies. The Inter-Agency committeo of the

$$
\text { IM1nutes, F.C.T.C., October S, } 1930 .
$$


Counc1l formulated statements of the division of respons1bility between the various private agencies and the Department of Welfare. The counc1l then distributed them to the agencies in the commity and to other:sources of referral such as the churches. The secretary pointed out that it was the council's job to understand the obligations of government in the fleld of social relfare.

The increased relief needs reflected the growing unemployment situation and for months the Council urged the Department of Welfare and the Board of Trade to appoint a committee on the Stabilization of Employment in Industry, but to no ava1l. At length in the fall the situation became too critical for the beginning of a stabilization program. Something had to be done to take care of the situation as it stood because of the rellef crisis in the 3 agencies. The impression the agencies had was that there was an increase in unemployment but no one knew how great an increase. Following the council princlple that facts should precede action, the Director of the Department of Public Welfare had a two day registration of the unemployed

\footnotetext{
${ }^{1}$ Minutes, Inter-Agency Committee, F.C.F.C., October 23,1930

Rinutes, F.C.W.C., October 6, 1930.

3 Minutes, Executive Committee, F.C.W.C., September 26,1930 .
} 
1

in October, 1930. In November the Loulsville Unemployment Rellef Bureau opened to provide work rellef. The Inter-Ageney Committee outlined the arrangements and procedures connected with the use of the Bureau and included methods of referral of all types of clionts. The council tried to interpret these plans to the public and sent notices outlining the Bureau's work to the soclal agencles, the Ministerial Association, and other groups. With many different types of relief necessary and a lack of funds the Family and Child Welfare Council made it possible for the agencies to come to some understanding of the division of responsibility through arranging metings for those concerned.

During 1931, committees from the Family and Child Welfare Council, the Recreation and Health Councils united in holding meetings with orphanage superintendents and staffs to discuss recreation in institutions, health and diets of children, the intake of bables, and the use of disclpline. 3 Elght meetings were held and in addition to the benefits felt to be secured from the discussion of

${ }^{1}$ Gourter-Journal, October 29, 1930.

2Minutes, Inter-Agency Comittee, Decomber 28, 1930.

3 Minutes, F.C.W.C., March 6, 1931. 
the topios was the actual participation of the various orphanage heads.

In the interest of securing a more coordinated program for children's work, the Children's Protective Association and the Children's Bureau combined their function June 1, 1931, in one organization known as the Children's Agency. Although this merger seems to have been the wise thing, the Family and Child Wolfare Councll was not consulted in planning or effecting it. The question naturally arises why the council with its background of knowledge of community needs and facilities was not asked to. participate in the plans. After the merger the Chlidren's Agency considered resuming the investigation of applications for the East End Day Nurgery which had been done by the Children's Bureau for three months in 1930 on a trial basis. The Children's Agency asked that the Day Nursery Committee of the council study the situation and make recomendations. The study was not completed unt1l March, 1932, and the findings indicated that there would be no improvement in the status of the nursery families unless intensive casework was avallable. It was pointed out that this need 1931.

$I_{\text {Minutes, Executive Committee, F.C.H.C., January } 30,}$ ${ }^{2}$ Ib1d., December 11, 1931. 
1

had been reported in 1926. As a result of the study, Children's Ageney was agked to do the social case work for the East Fnd Day Nursery. Upon the recommendation of the Illegitimacy Committee the Children's Agency continued the case work service to the Susan Speed Davis Hone that had been Initiated by the Children's Protective Association, and by 1932 all case work with umarried mothers not living with their families was centralized in the Children's Agency.

The Loulsville and Jefferson County Mothers' Ald Department requested the Family and Child Nelfare Council to take some action about the plight of the mothers who were not getting their checks pending a judicial decision affecting the appropriation. The council appointed a subcommittee to take this up with the County Judge and shortiy afterwands Mothers' Ald was assured that the immediate needs of the mothers would be met.

Louigville was fortunate in already having in 1932 an organization such as the Family and Child Welfare Council representing both the public and private relief giving

1 Minutes, F.C.F.C., Apr11 6, 1932. 1932.

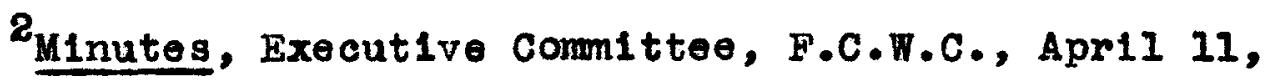
${ }^{3}$ Ib1d., Oetober 4,1931 . 
agencies that could be designated by the American Red Cross as the Central Relief Comitteo in Loulsvillo for the distribution of surplus wheat and cotton. In this capacity, the Council determined the needs of the territory, passed on agency requests and was accountable for 1ts distribution. Not only was the Council interested in specific problems and gaps in the comnunity but it was conoerned Wth specific ageney procedure, such as referral sumnaries, intake statements, procedures for out-of-town inquiries, personnel standards and a uniform scale of salaries for caseworkers. When the Execut1 ve Conmittee of the Chest felt that salaries of caseworkers should be cut for 1932, the Family and Child Welfare Council pointed out that during such times the soctal workers were more hard pressed than usual and were not in the same situation as business who had less to do.

Nineteen-thirty-three and 1934 were years which were notable for the decrease in activity in the Fam1ly and Child Welfare and Recreation Counc1l. Th1s was probably due to the lack of executive direction, for during these years both councils were having difficulty in keoping an

$1_{\text {Minutes, F.C.W.C., March 31, } 1933 .}$ 1931.

2 Minutes, Executive Comittee, F.C.W.C., October 26, 
execut1ve.

The last annual meeting of the Family and child Welfare Committee unt1l March 1934 was held in March, 1933, and the last Council meeting was held in October, 1933.

When the councils were formed much of the first years were spent in working out detalls of organization and polloy and it was not expected that any comprehensive soclal planning would be done. During the jears 1928-1934, the social planning of the Councils was still on a hit-or-miss basis. Studies and surveys were made as the need arose and definite lacks in the community social program were discovered, but no "master plan" was worked out whereby each year certain definite inadequacies were "attacked" with the idea of remedying the situation. It seems that the councils did not stop to take stock of where they were going or what effect they were really having and had not clearly defined their functions.

On Maroh 2, 1934, the plan was presented for the Family and Child Welfare and Recreation Councils to work together with a joint executive secretary, and the Executive committees of both councils agreed to try it on a temporary basis with the possibility of a permanent consolidation in the future, if desirable.

The first joint Executive Committee meeting of the 
Council was held May 17, 1934. At this time the Social Service Exchange requested mombership as a commlttee of the Councils and it was adnitted. The Recreation Council announced that a recreation instructor had been obtained for the University on the basis of the Counc1l assuming a part of the cost.

On November 2, 1934, the first joint meeting of the Counctls was held. The problem of jouth and delinquency and its relation to economic insecurity was discussed. This topic was directly related to the principles involved in the merger of the two councils for both recognized that community problems were not isolated entities and that for sound social planning cooperation and coordination of all factors were necessary.

Summary

It has been pointed out that during the period from 1928-1934, the rellef problems were increasing in Louisvilie and that there was a growth of public agencles to meet the Increased pressure which was becoming unbearable for the private agencles. The counc1ls were faced with these problems: to help the agencles to define their areas of responsibility, to interpret the plans to the public, and to emphasize that clients must still be recognized as 
individuals and that emotional needs as well as physical needs must be met. The Family and Ch1ld Welfare Counc1l through the Inter-Agency Committee made possible opportunities for representatives from the newly formed public agency and the established private agencles to discuss the areas of their work. The Counc1l through its members and through publicity attempted to interpret these plans to the community. The Recreation Councli realized that people had more leisure time than ever in their lives and it worked out programs with the public and private agencles to help the people spend this time wisely.

In addition to the ooncern of the Councils with the problems related to these new developments in the field of social welfare, the councils continued their interest in the flelds of illegitimacy, transioncy, training for staff members and volunteer workers, day nurseries and orphanages, and social logislation. 
CHAPTER VI

THE COUNCIL OF SOCIAL AGENCIES, 1935-1939 


\section{CHAPTER VI}

THE COUNCIL OF SOCIAL AGENCIES, 1935-1939

Por the firgt time in the history of the United States people began to look to the need for a permanent public program of social service. In the early stages of the depression people tried to convince each other that it was an emergency and that omergency measures would do. However, in this post-depression period during whioh the country was slowly trying to readjust 1 tself permanent public social service plans became a reallty. In 1933, nearly all public asgistance under the Federal Emergency Rellef Administration was provided in the form of general rellef with the exception of the civil Works Administration. During the fiscal year 1936 FERA grants were discontinued and several new agencles were established. The Work Projects Administration (originally called the Works Progress Administration) was established In 1935 to provide useful work on public projects for unemployed persons who were in need. The Federal Government also began to participate in three forms of public assistance at this time under the Social Security Act, approved In August, 1935. This act authorized Federal grants to the states for the aged, the blind, and dependent children. 
Other programs provided for in the Act include the insurance plans for unemployment compensation and old age and survivors benofits; public health and vocational rehabllitation; maternal and child welfare services; and services to crippled children, hameless, dependent, and neglected children and children in danger of becoming delinquent.

A Kentucky Department of Welfare Bulletin brlefly summarizes the developments that were taking place in the state social services:

The State Government Reorgani zation Act of 1936, set up the present Kentucky Department of Welfare, under a Commissioner, operating with an unpaid Advisory Board and responsible to the Governor of the State. In the Department as set up under the Reorgani zation Act of 1936, four divisions were provided--namely, Public Assistance, Mental Hyglene, Child Velfare, and corrections... The function of the Division of Public Assistance is to administer the organlzed programs for outdoor care of certaln types of Indigent persons of the State... With the passage of the Soc ial Security Act, the possibility of Federal-state participation in a state-wide program became a reality... This Division began operation when the McCarthy-Ramey Act, otherwise known as the old Age Assistance Act, was put in effect in 1936; 1ts field of operation being IImited to the one category of old age assistance.

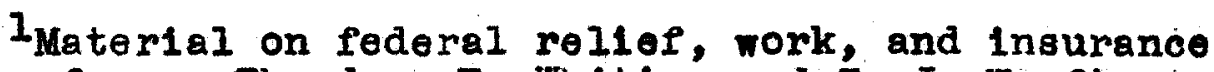
programs from: Theodore E. Whiting and T. J. Woofter, Jr., Summary of Rellef and Foderal Work Program Statistics, I933-1940 (United States Goverment Printing of 1 ice, Washington, D. C., 1941) pp. 1-16.

2 Kentucky Department of Welfare Bulletin, Vol. 4, No. 6, March and ApriI, 1943, (Kentucky Department of Welfare, Frankfort, Ky•) pp. 3-5, 18-23. 
The development of the public rellef agency in the Loulsville area also reflected this trend toward a permanent public soclal service system. From 1932 the city rellep office was known as the Municipal Rellef Bureau. In 1935, the name was changed to the Municlpal Bureau of Social Service and it was organized into two divisions-one division dealt with certifioation of employables for work projects and was financed with Federal funds and the other division gave help to the unemployables through use of local funds. It was known that Federal funds would not continue indefinitely and the Bureau realized that it was needed to 1111 a permanent place in the community.

Louisville was faced with a large transient problem when in 1935 the Federal Transient Bureau was closed leaving Loulsville agenoles to establish a program to meet the needs of the transient similar to the one that had been operative for five years prior to the opening of the Federal Transient Bureau.

During 1938 and 1939 the papers were filled with accounts of disagreements in the Department of Welfare and particularly the Municipal Bureau of Social Service. As a result many of the inadequacles of the rellef program in Loulspille were revealed, and although it was an unpleasant affair, it served the purpose of forcibly showing the public where the deflciencles lay. 
The Personnel Commission was organized March 15, 1938, to appoint employees on a merit basis for positions with the Departments of Health and Welfare as well as with other deparments. An attempt was made to pass the Juvenile Court Merit B111. to provide the merit system for the employees of the Jurenile court but it was declared unconstitutional. Broad changes such as these and newer trends of thought resulted in ohanges in other areas of social service in the community. The ldea was taking root that social planning to be good must be coordinated and inclusive.

For several months the Family and Child Welfare Councll and the Recreation Councli functioned as one unit with Mrs. Wood as the Executive Secretary, and in February, 1935, the Executive Committee proposed that the Councils be jolned permanently under the name "Counc1l of Social Agencles." 1 To merge the two councils permanently necessitated changes in the constitution of the Community Chest and since the Chest constitution was to be amended in February it was decided to suggest that provisions be made for the unification of the councils. The following amendment was accepted by the Central Council (Board of

\footnotetext{
$1_{\text {Minutes, Executive Committeo, F.C.W.C., February }}$ $5,1935$.
} 
Directors) of the chest:

Two councils shall be establishod as divisions or Couneils of the Community Chest, representing comprehensively the social work of Loulsville and Jefferson county. These councils shall be known as the councll of Soclal Agencies and the Health Council.

An amendment to the section dealing with the selection of the executive secretary of the council was also passed:

The Community Chest shall furnish Secretaries to the Counc1l, the selection of whom shall be approved by the Executive Committoo of the respective Counclis (Health and Council of Social Agencies). These Secretaries shall also serve as Asgistent Secretaries to the Executive Seoretary of the community Chest, and be so designated as such.?

New Articles of Agreement were written for the

Counoll of Social Agencles and were approved on April 26, 1935. Under the Articles of Agreement the membership of the Counc1l of Social Agencles consisted of agency delegates and committee members. Each agency had two representatives, usually the president of the board and the executive. All members of complttees were members of the Counc11. The entire Council membership met for the Annual meeting and occasionally during the year. In the interim the work of the counc1l was performed through the Executive Board and the committees. The Executive Board was composed

${ }^{1}$ Constitution of Community Chest (as amended February 6, 1935), Article VII, Section 1, A.

IIb1d., Article VII, Section 1, D. 
of the Chairman and V1ce-Chaiman of the Council, the chaimen of the standing committees and "not less than nine nor more than fifteen additional members appointed by the chalrman." ${ }^{1}$ The standing camittees were: Camp Clearing, Community Christmas, Inter-Agency, Transient, Children, Illegitimacy, Research, and the Advisory Committees of the Volunteers' Bureau and the Social Service Exchange. In 1938 a Steering Comittee was formed to advise the Secretary when requests came in for new activit1es. The budget for the councll was prepared by the Executive Board for presentation to the Community Chest. The budget provided for employing the Executive Secretary and a stenographer, and for expenses of operation.

This is the structure the Council was operating under in 1938-1939 when the Community Chest Survey was made by Mr. R. O. Loosley. The following recommendations were made for the Council of Social Agencies:

1. Relationship to the Chest a. The counc1 should cont inue to be a definite part of the chest organization and there should be a closer tie-up with the chest itself. b. Major recammendations of the council of Social Agencies (and Health Council) should be referred to the Executive committee of the chest. This would involve all such recomendations as have to do with

$I_{\text {Articles of Agreement of the Council of Social }}$ of Social Agencies (as amended April 26, 1935), Article VII, Section 1.

2 Annual Report, Counc1l of Soclal Agenc1es, May, 1937. 38. (Hereafter Council refers to Council of Social Agencies.) 
direct action a far as private agencles, public proerams, or proposed leglslation are conoernod.

c. There should be a still closer connection between both Councils and the Budget Comittes of the Chest.

d. That the budget requests of member agencies should continue to be made available to the secretaries of the Health Council and the Counc1l of Social Agencies for their analysis prior to a budget hearing.

2. Strengthening the council's program. a. Council structure

(1) Delegates and representatives should consider whether the divisional approach should be used, or whether the council should work through special comittees.

(2) In the organization of divisions, standing committees and special committees, that consideration be glven to the use of agency executives and interested lay persons as secretaries of such committeos in order to divide this important responsibility and relieve the secretary of the council to some extent.

(3) That the Secretary of the Volunteers' Bureau serve as secretary of the Camp Clearing Committeo. b. Counc11 Program

(1) That the reports of this survey and its recommendations in specific flelds be used as the starting point in the development of a Council program. (2) That the agencies be requested to fumlsh the Council with a list of those problems which they consider as needing Council study.

(3) That provisions be made for an annual appraisal of the outstanding problems that need the Council's attention, that the program for the year be blocked out with definiteness, that certain projects be selected in order of their importance for study, and that the progress of these projects be reported at the regular meetings of the councli, and a greater degree of executive control be exercised.

(4) That a program for the education of the council's own membership be developed at general or divialonal moetings throughout the year.

(5) That an extension of the Council's Bulletin be considered.

(6) That an annual appropriation be made by the Chest for apecial studies of fields or individual agencies where such studies cannot be made by the counc1l or local resources. 
(7) That the Social Service Exchange be recognized as a functioning unit of the council of Soolal Agencies.

(8) That the responsibility for collecting and tabulating the volume and cost figures be transferred to the statistics and research department.

(9) That the Secretary of the Chest assume more responsibility for coordinating the program of the Council with that of the other units of the chest. (10) That the counc1l of Social Agencles (and Health council) refrain from undertaking administrativo responsibility for any function that can or should be assumed by an individual agency. 1

In addition, Mr. Loosely thought that since the Volunteers' Bureau serves all agencies in the community, it should be considered as a unit of the Chest rather than part of the counc1l.

The Ioosley report was distributed in March, 1939, and on April 21, 1939, the Executive Comittee of the Council was considering the criticisms and recommendations. At this time, a special committee was appointed to plan and recommend the Council's organization in three divisions, of family welfare, child welfare, and group work. Another comittee was appointed to consider the working relationship of the Coune1l of Social Agencies with the Budget Committee, the Chest Executive Committee, and the Health Council. During the discussion of the Survey the question

${ }^{1}$ R. 0. Loosley, The Loul sv111e Survey, Chests and Counc1 1s, Section I, (MImeographed) March, 1939, pp. 1318.

${ }^{2}$ Ibid., p. 18. 
was ralsed whether a closer tle-up with the Chest would affect the councli relationship with the public agencles. The committee concluded that the counc1l should continue as a pert of the Chest, financed by the Chest and that the Volunteers' Bureau should continue as a commltteo of the Council of Social Agencies and not made a standing committeo of the chest as the Survey recommended.

The comnitter appointed to study the Counc1l organization agreed the council should try the three divisional plan. Other decisions reached were that the department of statistics be set up, the recommendations regarding the Budget Committee should be met and that major recommendations of the council concerned with direct action should be referred to the Executive Committee of the chest. When these suggestions were brought to the Executive Committee of the Council the members asked for clar1fication of the referral of actions involving polley and social legislation to the Chest Executive Committee. The presence of public agencies in the Council, the loss of time Involved and the question of the Executive Comittee having 1938.

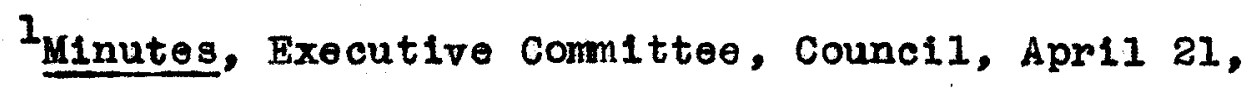

2M1nutes, Sub-Comitteo on Organization, Council, (filed with Executive Committeo Minutes) Apr11 26, 1939. 
any information upon which to base a dectsion were some of the arguments against the plan. Miss Stotsenberg brought out that "referral is an educative process rather than imposing authority as there is value in a council committee meeting with the Executive Committee of the Chest and educating 1 t. ${ }^{1}$

The survey had recommended that the members of the Council should list the problems they wished the counc1l to consider working on, and the Executive Committee agreed that a letter should go out to the agencles in the summer of 1939 so that the returns might be summarlzed and a program made up in the fall.

The Execut1 vo Compltee met in September and arranged some of the detalls of organization. Each agenoy was to be allowed two representatives in the division 1t selected to be a member of and could be represented in more than one division. A Planning Cormitter consisting of five members was to be organized in each division. Three members were to be selected by the division and two appointed from the Executive committee. It was also declded that only the Executive Committee and delegates should be asked to the

${ }^{1}$ Minutes, Executive Committee, Council, May 1, 1939. 2 Ibia. 
next council meeting and not all of the commlttee members.

The three divigions had organization meetings on September 28, 1939. In the meoting of the Family Welfare Division the hope was expressed that there would be an opportunity for the Planning commlttees of the three divialons to get together. It was decided that the InterAgency committee would be revamped as a small working committee directly under the Pamily Welfare Division. Dr. Margaret $K$. Strong of the Graduate Division of Social Administration was elected chalman of the Family and Child Welfare Division.

The Group Work Division and the Child Welfare Di Fision declded that lay persons should be the chalrmen of these divisions. All three divisions voted to have quarterly meetings. The Child Welfare Division felt that special meetings should be held for the institutional group allowing them to select their own topics. Up to this time there was no constitutional change made by the Counc1l to authorize this reorganization, but it was put

IIb1d., September 20, 1939.

2Minutes, Fam1ly Felfare Divis ion, Council, September 28, 1939 (filed at the Couneil of Social Agencles)

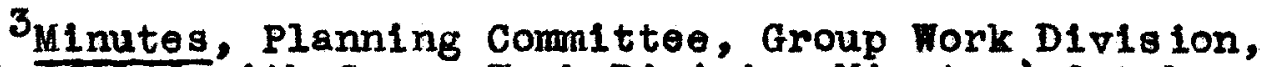
Councll TIIled with Group Work Division Minutes) October 24, 1939. 
into effect on trial basis at first.

The Constitution of the Community Chest defined in the following manner the duties of the councll of Soclal Agencles and the Health Counc11:

The duties of the Councils shall be in their respective flelds to study the soclal needs of the Community and to formulate principles, methodp and standards for the improvement of social work. I

The purposes of the Council of Soclal Agencles were not ohanged appreciably in the Articles of Agreement of 1935. The problem of adequate rellef continued to be paramount and much of the energy of the Council was directed toward seoking increased relief appropriations. With the reorganization of the Municlpal Bureau of Social Service on September 1, 1935, Loulsville had a permanent plan of social service financed by the city. Dr. K. P. Vinsel, Director of the Department of Welfare, urged increased appropriations so that direct rellef to the unemployed could be halted and work relief given to everyone. The chief means used by the council to seek more rellef for Loulsville cllents was through the preparation and mimeographing of a Bulletin devoted to the interpretation of statistics.

lconstitution of the communty Chest, (as amended Fobruary 6, 1935) Article VII, Section W.

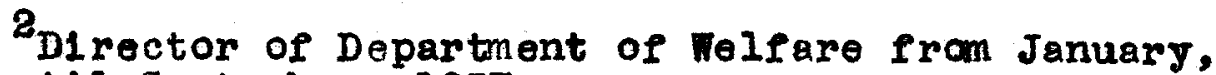
1933, until September, 1937. 
The Secretary complled the data and the Research Committeo worked with the Secretary in interpreting them. From 1935 through 1938, the Council issued three Bulletins dealing with local and national rellef trends. The councli continued to assist the agencies with their problems of defining their function and scope. The council also favored the proposed unification of the City and County Welfare Department into one organization and wrote to the Mayor's Legislative Committee to tell $\mathrm{hlm}$ of the Council's interest.

Not only was the council interested in the local department of welfare at this time, but it was also concorned with the need of state relief in the counties since the unemployables were the responsibility of the county judges. Dr. Vinsel addressed the county judges at their annual meeting in 1935 and made the following points.

1. Emergency rellef must be obtained from the state.

2. There should be a permanent State Department of welfare with good personnel and a trained worker in oach county unit.

3. County judges were asked to appoint a comitteo to go to the Governor to seek the necessary rellef.1

It was understood that the judges were interested in the plan but they made no effort to do anything about the situation.

The Counc1l realized in March, 1936, that unless State and Federal relief funds continued to be avallablo 1935.

1Minutes, Transient Committee, Counc11, December 13 , 
to the local areas that the rellef pleture for Loulsvilie would be very distressing. The counc1l passed a motion "recomnending to the State of Kentucky the need for continued State and Federal Funds." ${ }^{1}$ This motion was sent to the Governor and to the President of the United States. In spite of the Council's efforts State rellef funds were discontinued on April 1, 1936, and Federal rellef was halted on December 31, 1936.

The Inter-Agenoy commlttee of the Council was most energetic in working for adequate rellef for the Municlpal Bureau of Soclal service. The discord existing between the Welfare Department and the Personnel Commission had the effect of lowering the efflciency of operation of the Welfare Depertment and 1ts divisions. The Council was particularly concerned over the people for whom no relief was avallable. Persons in the following categorles were listed as being unable to obtain emergency or supplementary reller:

1. Able-bodied employable men

2. Certified for W.P.A. and waiting assignment

3. Working on W.P.A. but has not recelved first check

4. Those working on W.P.A. with large families for whom income is inadequate

5. Unemployables refuged agsistance because of same income aIthough insufficient. 3

${ }^{1}$ Minutes, Counc11, March 17, 1936.

${ }^{2}$ Courier-Journal, March 21, 1936.

3 Minutes, Counc11, May 14, 1938. 
Numerous discusgions and conferences were held to get the parties concerned together but there was a spirit of uncooperation present which oulminated in a public statement by the Director of Nelfare denounc ing the Counc1l as follows :

It becomes increasingly apparent, even to those who have occasional contact with tho social welfare facilities in Louisville, that the noed for integration and coordination 1s paramount. I feel it opportune to suggest a revamping of our planning agency, both in 2 regard to its organization, structure, and function.

It is difficult to judge the validity of this criticism of the Council of Soctal Agencles for even a brlef review of the studies of the work of the Director of Welfare would Indicate that his concopt of social relfare was inadequate to meet the needs of the Community. Apperently the Counc1l and Chest Ignored this outburst for no mention of it is made in the minutes.

The council continued its campalgn for increased appropriations for Mother's Ald in Loulsville and Jefferson County. A committee from the Counc1l studied Mother's Ald from November, 1934, at the request of the County Judge and the Board of the Louisville and Jefferson County Children's

$1_{\text {Mr. Solon Russell, Director of the Louisville Depart- }}$ ment of Welfare from December 1, 1937, until May 15, 1940.

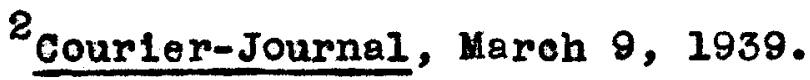


Home. In February, the committee met informally with the County Judge and recommended an increase in appropriation to care for cases on the walting $\frac{11}{1}$ st and to further study the administration of the program. In May, the Secretary reported that the county had increased 1ts appropriation and that the city had allocated forty thousand dollars for the fiscal year. The foeling at this time was that no definite recomendations regarding the future administration of Mother's Ald should be made since the passage of the Soclal Security Act was imminent, and it was hoped that Kentucky would participate in the Aid to Dependent Children program.

After the Social Security Act was passed August 14, 1935, the Executive Committeo was anxious for Loulsvilie and Kentucky to recelve the benefits of the plan. Plans were being made for the reorganization of the State Department of Welfare and the Executive Committee roted to send a letter from the councll covering certain recommendations as to the personnel of the department to the Governor. In 1933, The Federal Government had assumed the 1935.

${ }^{1}$ Minutes, Executive Comm1ttes, Council, February 5, 2 Minutes, Couno11, May 10, 1935. 1936.

3 Minutes, Executive Compltteo, Counc1l, February 7 , 
responsibility for transients and after operating the Federal Transient Bureau for two jears it was announced that the Bureau was to be closed on September 20, 1935. Provisions were made for all men in transient shelters, but the Counc1l transient Committee recognized the problem of the transient family for whom no local agency had funds ava1lable. It was suggested that an immodiate appeal be made by the camittee to Mr. George H. Goodman, State Administrator of the Kentucky Emergency Rellef Administration for funds to provide service to families with children. The committee met with Mr. Goodman on September 20, 1935 and a temporary plan was made whereby the Travelers' Ald would care for transient families and would be relmbursed by the Munleipal Bureau of Soc1al Service. The committee began to form plans for a central bureau of intake for transients and Mr. Goodman had agreed to finance it, but all plans were stopped by order from Washington which discontinued all rellef funds in Kentucky after December 1, 1935.

During the early months of 1936, the councll Translent Comitteo persisted in its demands for a Central Intake Bureau. In March, the Clty made an appropriation of ten 19,1935

${ }^{1}$ Minutes, Transient Committee, Council, September

$2_{\text {Ibid., October } 8,1935 .}$
$3_{\text {Ib1d., November } 15,1935 .}$ 
thousand six hundred dollars to the community chest for translent work, belleving that it was better to have this program handled through the chest than by the city. Under this arrangement the Transient Bureau interviewed all persons who were in the State less than one year, in the county less than six months, and also the state homeless. The Salvation Army objected to the establishment of the Central Intake Bureau and asked for aditional funds to provide a caseworker on its staff to be responsible for the transient program. In a meeting of the Transient Committee it was explained that the Bureau was not primarily to provide mols and lodging but to see that Loulsville would not have to care for more transients than should be justiflably taken care of by the community. At the conclusion of the meeting all agencles represented except the Salvation Army agreed to refer to the Central Intake Bureau all transients that applied during the hours the Bureau was open. Without the cooperation of everg agency it was impossible to prevent some duplication of service. The agencies were still unable to offer some plan that would attempt to meet the need of the transient constructively and not just to rid the community of his

\footnotetext{
${ }^{1}$ Ib1d., Apri1 6, 1936.

2Minutes, Transient Committee, Counc1l, April 6, 1936.
} 
presence.

Beginning late in 1936 and continuing into 1937

Loulsville had an increased number of transients because of rumors of jobs. The Salvation Army requested the council to call a meeting to disouss this influx. The Conmittee agreed that the agencles should discourage as many transients as possible and that a letter be sent to Dr. Vinsel and the Mayor asking their assistance in seeing that work rellef was given to Loulsvilie residents only. At a meeting of the Transient Committee in June, the Salvation Army reported Increased numbers of transients and suggested that a central intake bureau was needed. Other meetings during the year were devoted to discussing a work program for transients, the colored transients, and sick transients In an attempt to work out plans for the ir care.

Attempts were made by the Council to interest the County judges in taking some responsibility for their sick county transients but there was a decided lack of cooperation. The committeo realized that little could be done

${ }^{1}$ Ibid., February 18, 1937.

2 Ibia., June 4, 1937.

${ }^{3}$ Ibid., June 18, 1937, June 23, 1937, June 28, 1937 , September 17, 1937, September 21, 1937, October 8, 1937 and November 15,1937 . 
on a county basis without Federal or State assistence. A definite plan of division of responsibility was worked out between the Munfcipel Bureau of Social Service, the Children's Agency, the Pollce Department, Travelers'Ald, and Juvenile Court for all types of beggars, both resldent and nonresident.

According to the arrangements made when the Recreation and Family and Child Welfare Councils merged, the Council of Soclal Agencies provided the services of a group work Instructor at the University of Louisvilie as a demonstration. The council was unable to continue this project for another year, but the University of Louisville and the Department of Recreation made arrangements to keep the instructor for another year.

During the perlod from 1935-1939, the activity of the Council of Social Agencies in the recreation fleld consisted of the work of the camp clearing conmittee and the Volunteers' Bureau and participation in the following projects :

A study of all the surveys which had been made of the Public Department of Recreation and compliation

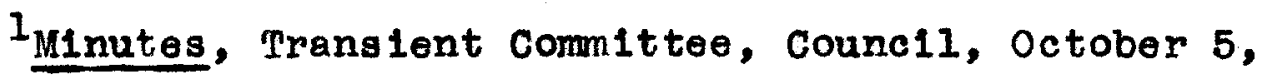
1938.

${ }^{2}$ Minutes, Executive Comittee, Counc11, Apr11 26,
} 


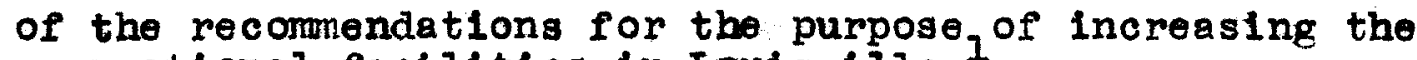
recreational facilitios in Loulsvilie.

A camp institute for camp directors, counselors, and volunteer leaders.

Census of camps in Kentucky made by the council at the request of the Nationel camp Association as a part of a survey of camplag facilities in the United States. Study of the recreation facilities in the nelghborhood of the Goodw111 Industries

Planned ${ }_{2}$ publicity on the need for recreation in the community.

The Illegitimecy committee continued its interest in Improving the work w1th unmarried mothers and from 1935-1939 it was concerned especially with the care of the venereally infected and the girls who were heving their second 1110gitimate child. In May, 1938, the Illegitimacy Comitteo was asked to consider the admission of venereal patients to the Susan Spe日d Davis Home and after an investigation of the facts the committee voted to approve of the Home taking care of a limited number of venereal cases with careful isolation measures as an experiment. 4 Prior to this action the Children's Agency was forced to place the girls in rooming houses scattered throughout town. A

1935.

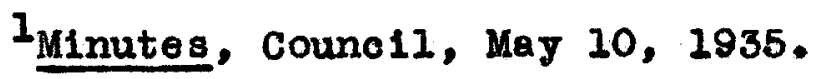
2 Ib1d., May 14, 1938.

3 Minutes, Executive committee, Council, February 5, 1938.

4inutes, Illeg1timacy Connittee, Counc11, May 23, 
re-evaluation of the division of responsibility between the agencies was made by the committee to determine how well the agencles were meeting the problem. Several meetinga of a case committee were held where suggestions were given as to how agencles might work together to best serve the clients. The Research Conmittee published the Bulletin on Statist1cs during 1936 and received the commendation of the Executive Committee for the continuance of 1 ts work because of 1ts value to staff and board members. The Research Committee polnted out the need for a person to work on statistics and moved that the Executive comnltter of the Councll recommend to the Execut1 ve Committee and the Budget Committee of the community Chest the establishment of a research and statistic division in the Chest. The Research Committeo voted to make a study of the Jennie cassiday Rest Cottage as requested by the Budget Committee of the Chest.

The Research Committeo published four Bulleting during 1937 on Chronics, Health, Child Welfare, and Recreation and camping. 1936.

l 15,1936 .

$2_{\text {Minutes, Executive Cormittee, Counc11, September }}$

$$
\begin{aligned}
& { }^{3} \text { Ibid., October 7, } 1936 . \\
& { }^{4} \text { Ibid., September 15, } 1936 .
\end{aligned}
$$


Publishing the Bulletins, approving studies and surveys, and collecting statistics for the Loosley Survey kept the Research Committee well occupled during 1938. The Chest requested the Council to make three studies of which the Executive Conmitteo approved:

1. The YMCA Camp and its place in the community

2. Review of cases of the Jewish Welfare Federation to determine how many might be transferred to Municipal Bureau of Social Service

3. Possible study of coodwill Industries if they stili wish to be admitted to the community chest

The Research Committeo began urging the City Planning and zoning Commission in 1938 to include a sum in its budget in order that the 1940 census could be taken on the basis of Louigrille Census tracts. The Council felt that there were many uses for statistics collected on this basis. The Comittee issued four Bulletins in 1938 on Health, Chronles, Feobleminded and Rellef bringing the total to seventeen Bulletins issued since March, 1935.

A oltizens' conmittee had been formed for the purpose of considering how to establish the merit system in the Juvenile court. It was suggested that the Counc1l

1Minutes, Counc11, February 25, 1938.

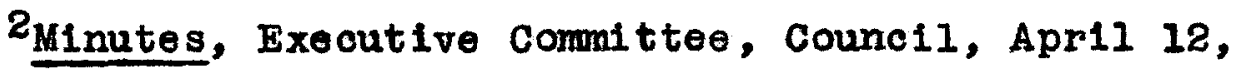
1938.

${ }^{3}$ Ibid., October 19, 1938. 
endorse the principle of the Juvenile Court adopting a merit system and make an offort to obtain legislation to accomplish the purpose. The Executive Committee discussed how far the Council should go in endorsing legislation and it was finally voted that the "Executive Committee looks with favor on any effort to obtain qualified persannel in social work." 1 The bill was discussed and analyzed by the Executive Comittee and the inclusion of the Council of Social Agencies as the organization to submit the list of names to the county Judge from which a merit board of four was to be selected was approved. When the fict was contested the council voted to allow the legal defense of B11l be made in 1 ts name. In spite of the efforts made the Bill was declared unconstitutional.

The Council particlpated in these additional activities prior to its reorganization in 1939:

Through the work of the Inter-Agency Complttee the two hour course in nutrition was arranged in connection with the Home Economics Department of the University for case workers and public health nurses.4 1938.

1 Minutes, Execut1 Committee, Counc11, January 17,

${ }^{2}$ Ib1d., Fobruary 25, 1938.

3 Ibid., May 4, 1938.

${ }^{4}$ Ibid., October 7, 1936. 
Serles of lectures sponsored by the Councll under the title of 'Inow Your Community' for members of women's clubs and civic organizations. 1

Assisted Volunteers Bureau and Department of Public Welfare establish lay advisory comitteos.

The Social Service Exchange as a commltteo of the Council was called upon to clear 32,857 names from Pebruary 1 through Maroh 1, 1937, for Red Cross disaster relief after the flood.

The Councli in cooperation with the National Youth Administration compiled and published a Directory of The Soclal Agencies of Loulsvilie in 1938.

Nineteen hundred and thirty-nine was a year of reorganization in the Councli and most of the functions pertaining to community problems took place in the early months of the year. The council continued publishing the Bulletin and collecting statiaties for the cost and volume of social work study for the United States Children's Bureau. The Volunteers' Bureau, with Miss Elizabeth Fike as Secretary provided training courses for churchwomen, board members of solal agencies, the Junfor League, and hlgh school girls. The Transient committee and the Council proposed that the State Conference of Social Work appoint a committee to investigate existing resources in the counties for the return of sick and needy Kentuckians. The InterAgency Committee operated as a conference medium to discuss the problem of reloceting the families living in slum

\footnotetext{
1Loulsville Times, October 3, 1936. 1938 .

2Minutes, Executive Committee, Council, April 12,
} 
areas which were part of the slum clearance project. The Children's Committee was active in urging support of the State Weifare Department in its offort to have Kentucky qualify for the Federal Aid to Dependent Children program. After the plan for roorganlzing the council on a three dirisional basis was accepted and put into action, the divialons of the council were chlefly concerned with perfecting their organizational plans.

The Family Welfare Division heard a talk by the superintendent of the Municipal Bureau of Servic in which he read his estimate of rellef neods for Loulsville. The Board of Alderman had not accepted this estimate and discord ensued between the Director of Welfare and the Superintendent who was forced to resign. The Council was not concerned with personal disagreements, but it was concomed with the public's apparent lack of knowledge of conditions in the community. The Planning Committee of the Division decided there was need of a citizens' committee to make known the facts in the report, and the Counc1l of Churches and League of Women Voters were asked to form a committee of civic groups to take action on relief needs. This plan was later approved by these two

\footnotetext{
${ }^{1}$ Minutes, Fam1ly Welfare Division, Counc1l, October 23,1939
} 
organizations.

The Group Work Division made definite plans for studying the needs of young people in one particular area, but the study was not carried out unt1l 1940 .

The three divisions were organized in a period over which war hung like a shadow and they developed their program in a war-time community which would provide a real teat of their worth.

Summary

During this period the council experienced two reorganizations, one united the Recreation and Family and Child Welfare Counc1ls and the other abollshed the committee plan under which the counc1l had been functioning and replaced it with three divisions of Family Welfare, Child Welfare, and Group Work.

The Council was active in seiking increased reller funds, in demanding good personnel in the public agencies, in making studies of existing facilities for casework and recreation, in assisting in plans for handling the transient problem, in urging the state Department of Welfare to seek Federal funds for a state-wide Ald to Dependent Children

\footnotetext{
1Minutes, Group Work D17ision, Counc11, December 29,1939 .
} 
and Ald to the Needy Blind Program, in offering institutes and training courses and interpreting to the public the community's needs and the existing services. 


\section{CHAPTER VII}

THE COUNCIL OF SOCIAL AGENCIES, 1940-1943 


\section{CHAPTER VII}

\section{THE COONCIL OF SOCIAL AGENCIES, 1940-1943}

The special knowledge and skills of social workers and the resources of social agencles must be used effectively in defense.... The present social problems are not new and different from those with wh1ch social workers are currently dealing. They are increased in some areas, decreased in others. They are intensified and often relocated. Our existing social machinery can be utilized. It needs adaptation to changing situations.... Social workers, to be useful, must be able to assemble and present facts, to undertake with other groups, broad community planning. 1

Loulsville was one of the fortunate clties that had the existing machinery necessary to meet the impacts of a defense program and later a war program. The Council of Social Agencles, after flfteen years of working $w 1$ th the public and private agencles in Loulsville and of bullding up a respect in the community for its work was prepared to adjust its poace time program to wartime noeds.

Loutsville was threatened with increased problems of dependency, migration, translency, health, housing, recreation, care for children, etc., as a result of the men being called by the Selective Service, people moving to Industrial areas seoking jobs in defense plants, women

IJane Hoey, President of the National Conference of Social Work, (Quoted in Annual Report of the Loulsville Council of Social Agencies, 1940-41). 
entering factories, and cost of living increases. Scarcity of certain 10N cost foods necessary for minimum standard diet made it diffcult for rellef families to supply their needs. In this era of increasing wages the problem of adequate rollef still provalled. The discontinuance of the Works Progress Administration, National Youth Administration and the Pood Stamp Plan in 1943 necessitated definite community re-adjus tments.

Loulsville was making some progress in the soclal welfare field, however. In 1940 the General Assembly passed the long sought Ald to Dependent Children and Ald to the Needy Blind Acts, in cooperation with the provisions of the Social Security Act. However, due to constitutional diffloultios the funds appropriated for the two programs were not available for their operation until June, 1942. The Child Adoption Bill passed by the legislature became effective in June, 1940. The Kentucky Department of Welfare Bulletin states that by law, the Department of Welfare through its Division of Child Welfare must investigate, upon being properly notified by the county court, all petitions of persons wishing to adopt minor children. Another step toward greater unity was the merger of the

lElizabeth Fike, "The Divisi an of Ohild Welfare," Kentucky Department of Welfare Bulletin, Vol. 4, No. 6 ," March and ApriI, I943, p. 6 . 
Clty County Health Department. The Division of Recreation was removed from the Department of Nelfare and was establishod under the Department of Parks and Recreation. In 1943, a Juvenile Court Trial Commissioner was appointed to have hearings daily thus preventing many ohildren from staying in the Children's center.

Whether there were social problems to be faced or problems resulting from inter-agency adjustments the council of Soclal Agencles offered a means of working out some understanding. The Council of Soclal Agencles operated on the three divisional basis as recommended in the Loosley study for three jears as an experiment. After one year of operation the Planning Complttee of the Executive Comnittee and the Executive committeo held metings to discuss how the organization was working, what comittees wore necessary and whether change should be made in the Articles of Agreement at this time. The revision of the Articles was left to a later date after the councll had more experience under the new organization. In November, 1941, the Articles of Agreement were revised incorporating the three divisional plan. The Articles of Agreement state:

Each ageney in the Council shall declde to which

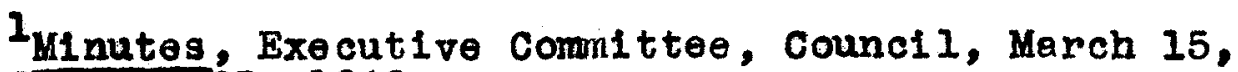
1940 and AprII 23, 1940. 
Division 1t wishes to belong, and may be a member of more than one Divigion. The Council delegates of each agency shall become members of the Division or Divigions to which the agency belongs.

As under the previous Articles each member organization of the Council is represented by two delegates "who shall when practical, be a board member and a stafe member in the case of private agencies, and an interested citizen and a staff member in the case of public agencles."

The officers of the Counc1l are a Chalrman, First Vice-Chairman, and the Chaimen of the Family Welfare Division, Group Work Division and Child Welfare Division who serve as Second, Third, and Fourth Vice-Cheimen. The Chaiman and First Vice Chalman are elected by the council. A Planning Committee is elected in each of the divisions and the chaiman elected by this committee serves as chairman of the Division. The Executive Comitter of the Council is composed of the "ofitcers of the council; six members elected by the councll; one member from each Division elected by the Division; the Chairman of the Advisory Commiteo of the Volunteers' Bureau and the Soclal Service Exchange; and six members appointed by the Chairman of the counoli." 3 The function of this committee is to act

${ }^{1}$ Articles of Agreement, Council (As amended November 6, 1941), Article XI, Section 1. (See Appendix I)

${ }^{2}$ Ibid., Article IV, Section 1.

${ }^{3}$ Ibla., Article VII, Section 1 . 
for the Council in the interim between meetings. The chalrmen of the divisions are given the power to appoint special or standing committeos as the need arises. The executio secretary of the councll is appointed in accordance with the Chest Constitution as follows:

The Executive Secretary (Chest) shall be respons1ble to the Board of Directors for the organization and coordination of a suitable staff for each the Councll of Soc1al Agenoles and Health Council, to be seleoted With the approval of the conmittee, however named fulfilling the function of executive committee of such coune11. 1

The Chest-Counc1l relationsh1p was redefined under

the Chest By-Laws of 1940 as follows:

The planning function of the Community Chest shall be discharged by the Council of Soc1al Agencles and the Health Counc1l, which 111 represent all the ageneies as far as possible, public and private within their respective flelds. Such Counclis may drat up their own rules and regulations, subject to the approval of the Board of Directors and conforming to the by-lams of the Community Chest. They shall also provide for the election of their own officers...2

The Council of Soclal Agencles had the number of 1 ts representatives on the Board of Directors of the Chest (formerly Executive Comittee) reduced from two to one. In the past there was one representative from the Family and Child Welfare Counc1l and one from the Recreation Counc1l.

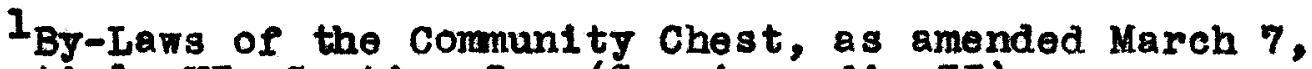
1940. Article VI, Section 3. (Seo Appendix II).

2Ib1d., Article VII, Section 4. 
The lay people asked to particlpate in the work of the Council were selected because of their interest and understanding of social conditions in Loulsville. After an interview with Mrs. Wood it was felt that the Council is interested in broadening its base of participation but it is difficult to find persons in the groups which they seek to have represented who heve interest in the work of the Counc1l. It would seem valuable to have a labor representative because many of the clients of social agencies are union members, and unions have become very articulate bodies in Louisville. It would be well to have them correctly informed about social conditions in the city and the types of facilities nooded to met them. It is possible a labor representative could contribute a greater understanding of the working man and his problems as he seos them. In 1941, when there was a vacancy on the Planning Committee of the Fomily Welfare Division the Committeo agreed that labor organizations should be contacted to find out if they were interested in having a representative on the Council of Soolal Agene1es. The Group Work Division has also been interested in labor ropresentation, but no one has been

I Personal Interview with Mrs. Loulse R. Wood, September, 1943.

${ }^{2}$ Minutes, Planning Conmittee, Family Welfare Division, Counc11, Fobruary 12, 1941 . 
appointed at this time. The council has always had representation from the colored agencies, but it was not until 1942 that the Council voted that Negro representation should be provided for on the Executive Committee of the Counc11.

Mrs. Loulse R. Wood continued to serve as Executive Seoretary of the counc1l. The councll had long recommended the employment of a soclal statistician as an addition to the Chest-Council staff, and in March, 1942, it was announced that Dr. Emest Greenwood had been employed to serve as research consultant for the Chest and Councils. The Volunteers' Bureau Recreation Committee recomendod that the Group Work Division request the Counc1I Executive Conmitter to consider the noed for a specialist in group work on the Council of Social Agencies staff. Conferences were held with the Mayor and the Director of Welfare to discuss the relation of a group work specialist to the program of the Division of Recreation. In December, 1942, the Community chest granted the request of the Counc1l for this addition to the staff for one year with no commitments for a longer period. The standards for the job were set and the follow ing months were spent in seoking 1942 .

${ }^{1}$ Minutes, Executive Committee, Council, March 31, 
a qualified person. At length, the proper person was found and Miss Meta K. Schwiebert arrived August 29, 1943.

So far, in the discussion of the organization of the Counc1l it seems as if war had little affect on the structure of the Counc1l. But such was not the case. In July, 1940, the Mayor appointed a conmitteo primarily for the purpose of dealing with the soldier situetion in Loulsvilie. This comittee was known as the Mayor's Military Affairs Comittee. The Director of the Department of Welfare with the help of the Federal Security Ageney drafted a proposed plan of community organization to be headed by the Mayor's committer, but with the understanding that this committee should be expanded to give the soclal work leadership of the city more representation. The proposed plan was first presented to the Executive Committee of the Council of Soclal Agencies in January, 1941. Although a broad social planning comnlttee was provided for in the plan it never materlalized for the Mayor's Committee concentrated 1ts efforts on organizing the Service Club in the old Columbia HaIl.

The Mayor's Milltary Affairs Comittee was replaced In 1942 by the Loulsville Defense Counc1l. The Division of Welfare, Defense Welfare Services, was of special interest to the Council of Social Agencles, and the Secretary of the 
Council and the Exeoutive Committeo conferred with the

Director of Welfare during the formation of $1 \mathrm{t}$. The

Division of Welfare sent out a memorandum of explanation

which describes the organization as follows:

The Divigion of Welfare of the Loulsville Defenge Counc1l, wh1ch Includes the metropolitan area of Loulsville, proceeds upon two bas1e propostions: first, it is necessary to provide for those-services which are of a continuing nature under the defense program; second, it is necessary to provide for thas services which can be put into action ghould an emergency arise.

With reference to the I1rst promise, there has been established under the Division of Welfare a section of Defense Welfare Servicos. Th1s section is set up to provide for a section chalrman, and associate section chaiman, aecretary, and a chaiman and membership of each of four committees, namely, Family Security, Social Protection, Consumer Interest, and Selective Service Assistance.

It is felt that the Family Securlty Committee should be concerned with such problems as housing conditions, transiency, migration, care of chlldren of working mothers, etc.

The Committee on Social Protection would be concermed with delinquency, with perticular reference to transient women and giris, the social aspects of prostitution, and rehabilitative measures in connection therewith.

It is suggested that the Committee on Consumer interest shall act as a clearance channel for all types of information vital to the consumer--broadiy speaking, to help the consumer aid the Government and help the Government aid the consumer.

The Committee on Selective Service assistance rill be concerned with matters relating to dependency clalms of selectees, assistance to persons rejected by selective Service, and 111 keep abreast of developments conceming dependency allotments. 1

IFrom the files of the secretary of the council of Social Agenc1es. Isgued January 12, 1942. 
The Chairman and the Executive Secretary of the Counc11 of Soclal Agencles were asked to fill these positions with the Defense Welfare Service also. The Comittees on Family Security, Soclal Protection and Selective Service Assistance were formed with professional social workers as chairmen. The Committee on Consumer Interest was formed but was disbanded since the qualified person appointed to serve as chairman could not continue.

At a meeting of the Executive committee of the Council in April, 1942, the Director of the Division of Welfare explained the growing conviction that the relationship of these services could be clarifled by a close tieup with the Counc1l of Social Agencles. The Executive Committee roted that the Council would agree to serve as the Defense Welfare Section of the Division of Welfare under the Loulsvilie Defense Coumcil. No change in the Articlos of Agreement was necessary for provision was mado for the appointment of special committees.

In January, 1943, a member of the Executive Committee of the Counctl of Soclal Agencles proposed the formation of a standing citizens" comittee to "constantly

\footnotetext{
$1_{\text {Minutes, Executive Committee, Counc1l, September }}$ 11,1942

${ }^{2}$ Ibid., April 17, 1942. (See Appendix III.)
} 
investigate all community problems and to keep the community aware of them." This committee was to be composed of unpald members but would be glven officlal status through appointment by the Mayor. The Executive Committee member explained why such a comittee was needed: The Council of Soclal Agencies had no official status, no organ of expression, and it does not represent such groups as business, churches, labor, etc., and in the minds of the community, it represents primarily professional social work. Therefore, it cannot perform the functions of such a citizens'

Before the close of the meeting it was decided to request the Mayor to appoint a Social Planning Commission.

The Mayor was out of town for a few months and the matter was taken up with the Acting-Mayor and the County Judge, and it was agreed that a Commission of seven members would be appointed including a representative of the council of Soclal Agencies. The moeting with the seven representatives from different groups in the community was held in Apr11, 1943, and the purpose of the Commission was explained. The following statement briefly summarizes the definition of the function of the commission and the council:

The Council studies, recomends, and plans; the Commission pushes for action.2 1943.

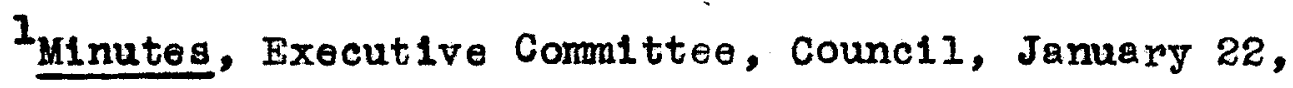

${ }^{2}$ Ibia., April 5, 1943. (See Appendix IV.) 
The representatives listened to the explanation and afterwards declded that such a group would not be able to achleve more than the council since it would have no authority to raise funds and they suggested the Council continue to do the social planning for the community. Faced with this lack of interest the council felt it was futile to push the matter. It is interesting that al though individual members of the Council of Social Agenoles felt the need for an offlelal group to interpret social work to the community and to strive for broader social planning this proposal has not resulted in the council recognizing the necessity to reevaluate its services to the community and to discuss how the gaps mentioned above could best be met.

The revised by-1aws of the Community Chest defined in general terms the duties of the Councli of Social Ageneles and the Health Council:

The duties of these counclis shall be to inftiate and supervise all business relating to relationship between organlzations, standards of rork, to advise upon the requests of the Budget comittee regarding matters of social importance and to take such measures as may

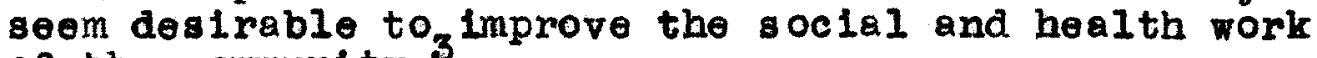
of the community.

${ }^{1}$ Ibid., May 18, 1943.

$2_{\text {Supre, pp. 153-154. }}$

3 By-Laws, Community Chest (as revised March 7, 1940) Artiole VI, Section 4. 
According to the wording of the chest by-laws the functions of the Councils were more definitely expressed and there was an implication of greater authority. When the Articles of Agreement were revised in 1941 the purposes of the Counc1I of Social Agencies were enlarged on as follows:

The purposes of the Cancil of Social Agencies are: a. To aid in community social planning by coordinating the services of the existing agencies and by gathering factual material which will reveal noeds and lead to the creation of new programs which will help to meet these needs.

b. To carry on a program of education for the citizens of the community recognizing the need for social services and the standards which must be maintained if these services are to be performed effectively. c. To engage in direct social action whe re such action is deemed necessary to effect desirable changes In community $11 f \theta$. d. To administer certain services that can be provided most advantageously by a central body.1

To serve these purposes the Council's Difisions functioned. Certain standing committees were retained such as the Camp Committee and the Camp Clearing Committee of the Group Work Division, the Statistios Committee, the Advisory Committeo of the Clvilian Defense Volunteer Office (fomerly Volunteers' Bureau), the social Service Exchange Advisory Committee, and the Community Christmas Comnittee. In addition there were also the three comittees of the Defense Welfare Services. The three committees of Family Security, Social Protection,

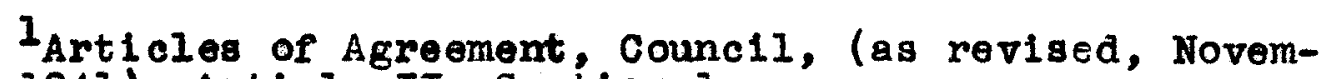
ber 6, 1941), Article II, Soction 1 . 
and Selective Service Assistance worked in close contact with the Divisions of the Councll and made progress reports at intervals.

The Family Welfare Division decided at its first Executive Meoting of 1940 that the major job of the D1 vision was to interpret family welpare with emphasis on the relier problem. To carry out this plan, four projects were started. A sub-comnlttee on Intake arrange a statistical study of rejectiong for all agencies with intake departments for the three month period from March 1 to June 1. A special committee was appointed to study wat happened to one hundred cases of rejections in December, 1939, at the Municlpal Bureau of Social Service. A sub-committee worked on statements to interpret the Family Welfare Division in the Bulletin 1ssued in April, 1940. Intake statements of the Agencles were revised and distributed.

The rejection tabulation was included at the end of the relief study of "One Hundred Cases of Rejection" which was distributed through the holp of the Work Projects Administration and the National Youth Administration. The results of the study are interpreted as follows in the Annual Report for 1940-41:

It spurred interest in the urgeney of the need for more adequate relief and was instrumental in helping to get an Increased budget for relief, but the amount 
provided still falls far short of moeting the nood in view of increasing rents and food prices.1

The members of the councll were not content to publish the facts about urgency $f$ or more reller, but wrote letters to the Point of Vlew Columns of the newspapers and interviered the members of the Finance Committee of the Board of Alderman personally.

From 1935 through June, 1940, the Municipal Bureau of Social Service had been responsible for Investigating the needs of Individual applicants for the Work Projects Administration and for cortifying to the H.P.A. their eligibility on the basis of noed. This function was to be delegated to the Kentucky Department of Welfare after July 1, 1940, but since the state Department of Welfare had made no plans for this work it looked as if W.P.A. would cease after July 1, 1940 in Kentucky. Th1s situation was brought to the attention of the Council of Soclal Agencies and the Executi comitteo of the Council was authorized to take whatever action seemed desirable after conferring with the W.P.A.

During 1941, the Family Welfare Division was con-

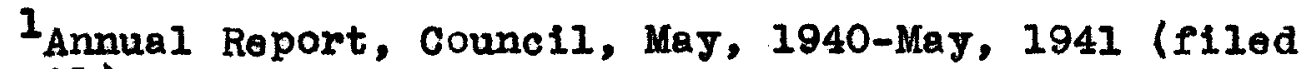
at Counc11). 1940.

2Minutes, Execut1ve Conmittee, Counc11, June 28, 
cerned with the probiems of the acute housing shortage and rising rents and the necessity for preventing unskilled transient workers from becoming dependents of the community. Several meetings were held to discuss housing, and nowspaper publicity was sought to inform the communtty of the prevalling conditions. The Division held meetings to discuss the non-residents and the new pollcies involving referral and service were evolved. Although the rief plcture was not as serlous as far as numbers was concerned, the Division continued 1ts interest in securing more adequete rellef for those who were getting assistance.

In November, 1941, the Family Welfare D1vision became interested in a project that it continued until July, 1943, with prospects of extending 1 t unt1l November. This s tudy which became known as the War connected Study was requested by Fam1ly Security Committee of the Federal Security Ageney. The plan was presented to the group of agencles that were concemed with family welfare and they agreed to cooperate if a competent director and staff could be secured. The possibility of securing assistance from

IMinutes, Family Welfare Division, Counc11, September 25, 1941.

${ }^{2}$ Minutes, Meeting of a group of agencies, November 5, 1941 (Flled with Family Welfare Division Minutes). 
the Federal Security Agency materialized and with the direction of Dr. Robert I. Kutak as Chalrman and Dr. Guy Stevenson of the University of Louisville, the study was begun March 1, 1942 .

The schedules were prepared with the help of two representatives of the Social Security Board and were given to the agencles having applieation departments to check. The committeo stated that the study would give a picture of all requests for assiatance as well as those which were "war connected." In October, the report of the study entitled "Impact of War and Defense on Loulsville and Jefferson County as Reflected in the Work of Fifteen Social Agencies--During March, April, May, 1942" was given. According to Dr. Kutak's report the agencies had recelved four thousand two hundred requests for service of which ten percent were war connected; seven out of ten requests were granted. It was felt at this time that the war had not created requests for new services, but seemed to intensify some of the routine problems which confronted communities in time of peace.

The Volunters of America petitioned the Council of Soclal Agencies and the Community chest for admission and the chest requested the council to make a study of the work

\footnotetext{
1 Minutes, Executive Comittee, Council, March 31, 1942. $19,1942 \cdot$

2 Minutes, Femily Welfare Division, Counc1l, October 3 Ib1d.
} 
of the Volunteers of America. An extensive study was made in June, 1942, the results of which appeared in a confident1al report. The recommendation of the council based on thls report was that the "application of the volunteers of America be rejected until such time as they could meet social case work standards." 1

The Family Welfare Division through one of its subcommittees complied a simplifled summary for the referral of cases. A special memorandum on the provisions of servicemen was also prepared. The Fam1ly welfare Division ant1clpated the great loss to the community when the work Projects Administration program and the Food Stamp Plan were discontinued in February, 1943. Since families receiving assistance through the Old Age Asgistance, Municipal Bureau of Soclal Service, Ald to Dependent Chlldren, and County Welfare also benefited Prom the Food Stamp Plan, the Family Welfare Division was concerned with how these people would recelve adequate food because their incomes were so inadequate. In addition the cost of $11 \mathrm{ring}$ had increased and familles were unable to buy as much with their money. A study of budget needs was made and presented at a meeting in the Aldermen's Chamber in June. The statement was made 
that "prevention is cheaper than cure. Reducing living standards invites disease, opidemics, delinquency, otc., for which the community must pay dearly."

During 1940 the projects to which the Child Felfare Division devoted most of lts efforts were: two meetings held In children's institutions to discuss "Discipline--Reward and Punishment," and the "Health of Child In An Institution;" meetings of the Illegitimacy Committee to plan the division of responsibility for state and non-resident cases; a committee to study the standards to be set up in the bill to license and inspect children's institutions; and a study of the State girls at the Susan Speed Davis Home.

Bills affecting child welfare before the State Legislature were brought to the attention of the Child Welfare Division, and although the Division as a group did not take any action it encouraged the members to work for their passage by writing to the senators and representatives. The legislation in which the Division was most concerned were the bills regarding adoption, ald to dependent children, and the licensing and inspection of boarding homes.

In 1941 the Child Welfare Division conducted a meeting

\footnotetext{
${ }^{I_{\text {Minutes, }}}$ Family Welfare Division, Counc11, June 25, 1943.

2Minutes, Child Welfare Division, Council, January 23, 1940 (IIIed at Council).
} 
on the discussion of the admission polloles of three children's institutions in Louisvilie. The Division continued its interest in forming plans for cooperation between the Louisville agencies and the State Department of Welfare for the care of state girls at the Susan Speed Davis Home. After the passage of the Ald to Dependent Children Act the Division was most active in seeking to have the Act declared onstitutional. The Division also held meetings to discuss the intake policies of various agencles in the community .

The Child Welfare Division in 1942 was concermed With the administration of the Ald to Dependent Children program in the State and the relation of the State program to the one already in operation in Jefferson County. A sub-committee of the Division formulated plans for the Ioulsville agencies to cooperate with the State Department of Welfare in the handing of the adoptions of state childrer In Loulsville. Cooperating with the Clvilian Defense Volunteer Office, the Chlid Welfare Division set up three training courses of five weeks each for the training of child care aldes. The course included information on mental bygiene, pediatries, nutrition and recreation.

${ }^{1}$ Minutes, Planning Commltter, Council, September 12, October 7 , Hovember 3 , and December 2,1941 .

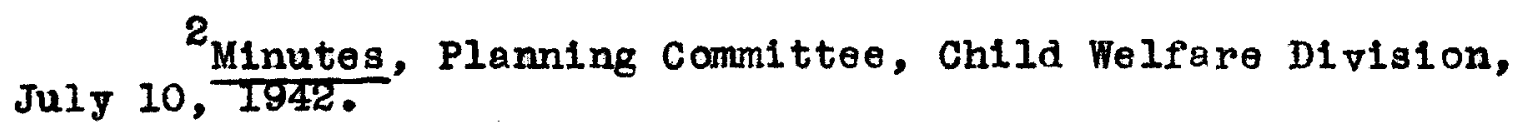


The Boarding Home Ordinance as passed before exempted day nurseries and institutions for children, and the Child Helfare Division Planning Committee appointed a comitteo to work on a revision since so many women were just starting nursery schools without consulting anyone.

A large moeting, sponsored by the Child Felfare Division, to discuss. Juvenile Delinquency was held on December 4, 1942. Many aspects of this problem relating to the facilities in Loulsville to handle it were diseusged and it was declded that the Child Welfare Planning comittee would continue to study delinquency.

The Child Welfare Planning Committee held conferences to discuss the proper administration of the Adoption Law and made recommendations at the request of the State chlld Welfare Division concerning local assistance. PIans were also being made by the Planning Comittee for a follow-up meeting on Delinquency and a program on what happens to chilaren in institutions during wartime.

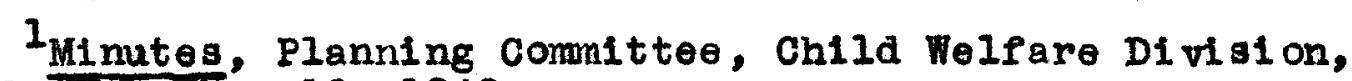
Council, November 19, 1942 . 1942 .

2Minutes, Child Welfare Division, Cancil, December 4,

${ }^{3}$ Minutes, Planning Committee, Child Welfare Division, Counc11, May 13, 1943.

${ }^{4}$ Ibid., May 19, 1943. 
The Group Work Division proposed several study groups such as a camp committee, a study of records, and an evaluation of groups but very little was accomplished in 1940. One study group, however, initiated a most extensive program. The representatives from the recreation agencies In the nelghborhood of clarksdale, the housing project, studied the recreational facilities of this area. It was found after a brief check of the questionnalres that there seemed to be numerous faclifties for recreation in the area, but the problem was lack of leadershlp and how to relate the existing resources to the clarksdale tenants. The proposed program at the new community center was also cansidered in relation to the other recreation agencies in the area. The Division began to consider the problem of recreation for the soldiers in Louisvilie and the ideas of a few agencies vere discussed at a meeting of the Planning committee.

At the request of the National Youth Administration a meoting was held with representatives from all of the agencles working with adolescents to discuss vocetions 1 counseling. As a result the Loulsvilie Vocational Guidance Council was set up to coordinate guidance activities for

lMinutes, Planning Comittee, Group Work Division, Counc11, December 10, 1940.

$$
\text { I Ibid. }
$$


1

the young people of Louisville. After a year spent in organizing the group no further activity took place because the assistance anticlpated from the State Employment office was not available and the Council was no longer responsible for the promotion of an educational project.

The Group Work Division felt that with the beginning of a recreation program at Clarkgdale under the auspices of the Division of Recreation the time and effort spent in the Area Study of 1940 was not in vain. The recreation agencies were also registering their cases with the Social Service Exchange, and the Group Work Division Planning Comittee suggested that the registrations of the recreation agencies in the area of clarksdalo be followed up to determine extent of duplication of membership.

The Camp Committee studied Negro camp facilities after complaints were made by the project manager at Otter creek that the Otter Creok facilities for Negroes was inadequately used. The study was completed in 1942 and the committee made the following report:

It is apparent that Camp Sky High (at Otter Croek) orlginaliy planned for the colored groups, having unexcelled facilities, dining hall, screened cabins, and 1940.

1Minutes, Execut1 ve Committe日, Council, June 28,

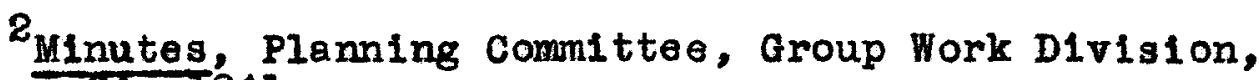
September 24, 1941 . 
swiming pool set in a natural setting conducive for the best type of camping, is not being used to its capacity. In view of the fact that there are insufficlent camping facilities in the community for white groups, the committee feels that in order to preserve the use of Sky High for colored groups that all agencies or groups interested in camping for the Negroes of this community be urged, through combined efforts, to make better use of Sky High.

To this end the work of the Division was directed.

The Group Work Division studied the need for a recreational institute or training course in connection with the Volunteers' Bureau, but after so few questionnalres which were sent out to determine interest were returned it was decided not to conduct an institute during 1941.

The Service club had begun operation under the direction of a sub-commitiee on recreation of the Mayor's Military Afralrs Committee on which the Group Work Division was represented.

The Executive Committee of the Community Chest requested the Group Work Planning Committee to sponsor a study of the program of the Boy Scouts of America which would be conducted in cooperation with representation from the national Boy Scout staff, to determine the need for a larger chest appropriation. A sub-comittee wes appointed

${ }^{1}$ Minutes, Executive Committee, Council, March 31, 
to make the study and they spent several months in working out the detalls of the study and discussing various points with the scout executive and board members. The committee attempted to consider the scouting program in relation to the whole community recreation plan. Th1s 1dea was not in accordance with the national Scout plan and many adjustments were necessary between the two groups. The study was not completed in 1941 when 1t was begun but the results were witheld until studies had been completed of other recreation agencies seoking additional appropriations.

The Group Work Division believing that the recreational neods of the community were increasing planned to sponsor In cooperation with the Clvilian Defense Volunteer Office two recreation institutes, one for white and one for colored volunteers. The Group Work Division reported: "The Inst1tutes, lasting five weeks each, included instruction in group games, social dancing, folk dancing, arts and crafts, and community music. The purpose of the training, which was given to 102 white people and forty colored people was to provide basic instruction for volunteers who could assist with recreation programs in churches and community centers. To make use of these trained volunteers the Civilian

$1_{\text {Annual' Report, 1941-1942, Counc1l, May, } 1942 .}$ 
Defense Volunteers offlce organized w1th W.P.A. assistance four mobile units of party leaders to serve churches and other organizations.

The study of colored camping facilities was such a success that the Group Work Division was requested to make a similar atudy of camping facilities for white chilaren.

The Graup Work Division, at the request of the Chest Budget Committer studied spe offe items in the budgets of five Chest recreation agencies which had requested an expansion of program. Sub-committees were appointed to study the Boy Scouts, Salvation Aminy and Rose Hudson Community Center, Young Men's Hebrew Association, Young Men's Christian Association and the Presbyterian Colored Missions. Before reaching a decision representatives from the study committees visited the Major to discuss with him the program of the public recreation department and its relation to the private agencies. The comnittee recommended that in view of limited public facilities, the acceptance of requests for expansion, if possible, but noted the inter-rolation of the public and private agenoies and the need for promoting citizen interest in a more adequate budget for the Recreation 2 Division.

${ }^{1}$ Minutes, Planning Comitteo, Group Work Division, Counc11, June I, 1942.

2 Ib1a., November $10,1942$. 
The Budget Conmittee of the Chest requested the Council to study the need for social service at the Convent of the Good Shepherd and the request of the East End Day Nursery for an additional nursery school teacher. The studies were referred to the Planning Committee of the Child Welfare Division, and sub-oommittees were appointed. The studies revealed an increased attendance at the day nursery and a need of more staff. It was also recomended that there was a need for a social service program at the Convent of the Good Shepherd.

The Group Work Divisional Meeting in December, 1942, was concerned particularly with war and recreational facilities in Loulsvilie. Mr. Don Wardell, Recreation Fleld Representative of the Office of Defense Health and Welfare Services discussed the need for community recreation during war time. The Division cooperated with Mr. Wardell in making a survey of avallable recreation facilities in Louisville. The attempts of the United Service Organizations to provide recreation for industrial workers was. also discussed.

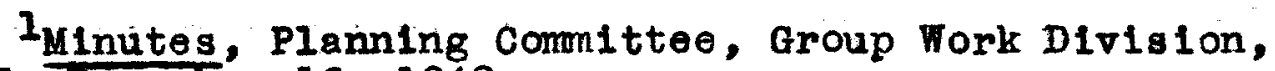
Counc1 1, December 16, 1942 . 1942 .

Minutes, Group Work Division, Counc11, December 28, 
The Group Work Division arranged for an institute on foik dancing conducted by Miss May Gadd during May, 1943.

The Division felt that the recreation program in the city was very inadequate and that its expansion depended on educating the public. The problem of providing recreation for industrial workerg was brought in $\mathrm{Mr}$. Wardell's roport in February and conferences were held with the Director of Parks and Recreation and the Director of Civilian Defense to explore the subject of community recreation.

The Area Study Cormittee continued to meet and it found there was need for a recreation program for adults working in defense plants. The comittee felt that a Negro Area Study rould be of benefit to the agencles seriving this group of people and an attempt was made in March to organize a Negro Committee. However, it was considered desirable to have the Impetus come from the Negro group and the Group Hork Division just offered to assist them in any. way possible.

In addition to the work of the Divisions the Council of Social Agencies was active in the organization of a stato Transient committee. The counc1l published Bulletins

\footnotetext{
April $20,1943$. Planning Committer, Group Work Division, IIb1d.
} 
through 1940 and since that time has published statistical summarles from data collected for the Chlldren's Bureau. The Social Service Exchange continues to function as a part of the counc1l.

The organization of the Defense Welfare Service has been described, but the work of the committees on Family Security, Social Protection, and Selective Service Assistance has not been discussed. Mrs. Wood explains that the council cannot assume any credit for the work of these defense committees although the secretary sat with them at meetings. She explaing that the committees were headed by competent professional people and that the "comltiees ran themselves." These committees are not considered permanent but are to meet the special needs arising out of war.

At the meeting of the Family Security Conmittee on April 16 the following were the problems felt to be within the scope of this commlttee: day care centers, increased housekeoping ald service, lack of housing facilities, migration of workers, dislocation of families, dislocation of workers through priorities unemployment. Sub-committees were appointed and the attention of the committee was

$1_{\text {Personal interview, September, } 1943 .}$

2 Minutes, Family Security Comittee, Defense Welfare Services, April 16,1942 (flied at Counc1I of Soclal Agencies.) 
Focused on the immediate problem of day care and housekeeping alde service. The Day Care Comitter was active in determining the actual number of mothers needing day care and, after exhausting all possible local sources of funds, was instrumental in getting the Board of Education to request assistance from the Lanham Act Funds. No meetIngs were beld by the Family Security conmittee from April unt1l November at which time it was decided that this committee should evaluate the situation and plan a program for 1943.

The Social Protection Committee was interested in the need for segregation, special treatmont and training of venerealiy Infocted women and girls. The Comitter was successful in obtaining a woman social worker for the women at the Workhouse. Many discussions were held and plans were being formulated for the use of the old Detention Home for care and training of these girls. However, it was decided to walt before dolng anything further until the State Board of Health had developed plans for a Communicable Disease Hospital so that there would not be a duplication of effort. The most valuable work of the Selective Service Assistance Conmittee was the assistance 1t gave the induction

IMinutes, Day Care Committeo, Family Security Comittee, November 24, Ig42 (filed with Family Security Comittee minutes at council). 
board psychiatrists in their examination of selectees. This conmlttee cleared all of the namos of boys classified 1-A through the Social Service Exchange and made arrangements for obtaining aignificant information from agency records which was presented confidentially to the psychiatrists. The committee was also interested in giving service to rejectees, but no successful plan was developed. Investigations for draft boards were also made by local agencles and the division of responsibility for different types of cases was defined by this committee and sent to the draft boards for their information.

The Conmittees under the Defense Helfare Services did not flle complete minutes with the counell for 1943 , but from the available material it is ovident that the Family Security Committee considered its job about finished and that its main function at present is a clearing house. The Day Care Committee has been very active since Lanham Act Funds became available to Louisville and four day nurgeries have been opened by the Board of Education and one by Neighborhood House. The Social Protection Committee was left without a major project when the State Board of Health was granted funds to establish a venereal hospltal at the Fair Grounds. The Selective Service Assistance Committee has continued to give information to Draft Boarda 
and Induction centerg and to try to help rejectees.

Summary

During the Jears 1940-1943, the Counc1l was const1tutionaliy organized on the three divisional basis of family welfare, child welfare, and group work. The war problems made it nocessary to form a Division of Defense Welfare Services under the Division of Welfare of the Loulsville Civilian Defense Counc1l. The three committees, Social Protection, Family Security, and Social Servico Assistance were formed under this Division to meet these problems .

The Family Welfare Divisi on conducted three major studies during this period from 1940 through June, 1943. Two of the studies were related to the relief problems in the community--one was a study of "A Hundred Cases of Rejections" and the other was a study of the plight of families recelving some form of public assistance when the Work Projects Administration was closed and the Food Stamp Plan was halted. The third study was made of the effects of war on the requests for service made to the agencies and to determine if existing agencies were meeting the needs of the community.

Much of the program of the Child Welfare Division was influenced by recent social legislation in Kentucky 
related to chlidren. After the passage of the Ald to Dependent Children Act the Division was active in seeking to have it declared constitutional, and later in urging adequate administration of it especially in Jefferson County where there was a well functioning ald to dependent ohlldren program. The Adoption Law was studied from the social and legal points of view.

The Group Work Division undertook an area study of the recreational facilities of twenty agencies, churches and organizations in the nelghborhood of clarksdale. Several studies were also made for the Budget Commlttee of the communlty chest. The Soldier's Service Club was opened and the Division cooperated in the plans and operation of the club. Several training institutes for volunteer workers were conducted by the Division.

In addition to these activities the council continued its work through the camp clearing comittee, the Christmas Committee and the Volunteers' Bureau expanded Into the Civilian Defense Volunteer office. 
CONCLUSIONS 


\section{CON CLUSIONS}

The Councll of Social Agencies in Loulgville is the social planning organization for the public and private social agencies in the city. The Health Council performs a similar gervice for the health agencies in Louisvilie and presents an area of future study. The Community Chest (or NeIfare League as it was known earlier) has been responsible for the formation of the councils and has been their source of financial support.

The Conmunity Council which operated from 19201923 was the first agency for social planning organized by the Welfare Ieague. Upon the organization of the Community Chest three councils were established and were functioning by 1925. The Health Council immediately received a suffolent budget allowance, while the Recreation Council and the Family and Child Welfare Couneil had to wait several years to receive funds to employ an execut1ve.

In 1935, the Recreation and Family and Child Welfare Councils were united to form the Council of Social Agencies. The various committees of the two councile continued to function under one executive until 1939, at which time the council adopted the three divisional plan suggested by Mr. R. O. Loosley in his survey of the chest and Counc1l. After a three jear trial the three divisions of 
Family Welfare, Child Welfare and Group Work were made permanent parts of the structure of the council.

The Council has always had representatives from public and private agencies and institutions including both lay and professional poople. Interested communty people also contributed to the work of the counc1l by committee participation. In the early years, the lay persons on the council had leadership in the community and an interest in social welfare, but mostly persons of wealth and position. In later years the attempt has been made to broaden the representation of the council, but adequate labor delegates are lacking at present.

The general purposes of the councll through the years have been to educate, to coordinate, to administer, and to act on social issues. In its early years the Council did not attempt much interpretation to the community out directed its efforts toward improving facilities for staff education. As these plans became established and as the council reallzed that intelligent community support was necessary, interpretation to the public through committeo participation and organized publicity methods was begun.

The Council has always considered the prevention of duplication of effort as one of its chief alms and has gone 
forward through the years to achleve this. At flrst there was the problem of adjusting the functions of existing community agencles and services to prevent overlapping, and later it was recessary to help agencies to redefine their functions as changing needs developed. The Council was often called upon to make studies for the chest to determine the usefulness of an agency's program to the community and to help decide if the money was needed more in one particular area of service than another. However, social planning is the antlthesis of a hit-and-miss procedure so characteristic of much of the cooperative offort in social work. It is predicated upon searching study and analysis. It premises the counseling together of all who have a concern in the problem. In the early days the Council apparently followed the bellef that the application of common sense and decision rendered by folks sitting around a table would solve the proglems of "overlook and overlap." Such could have possibly been true then, but in recent years, as cities have grown and as living has become more complex, planning has come to be based on impartial and searching studies which follow a broad general plan. In Louisville the Council has sought facts as a basis for its planning, but it would seom that in addition to asking the various agencies to submit suggestions for future study and 
action there is need for a definite long term planning. Unforeseen changes will naturally occur, but if the broad view is taken the agencles will probably be better able to meet these situations as they arise.

The Council has contributed to the service of the various agencies by administering certain activities which were Impractical for each agency to operate 1tself. These have included a Central Purchasing Bureau, A Soclal Service Exchange, the Volunteers' Bureau, and the collection of statistics for the United States Children's Bureau. The Social Service Exchange and the Volunteers' Bureau continue to have their own advisory committees.

The Couneil has definitely been interested in social action, although at times there may have been questions as to the best methods of procedure. Usually the Counc1l encouraged the Individuals to campaign for a particular "cause" by letters to the newspapers, personal contacts, or correspondence with legislators and administrators. In some instances such as Ald to Dependent Children and Ald to Needy Blind, the Boarding Home Ordinance licensing foster homes, relief appropriations, and administration of certain public programs, the council was most articulate and aggressive in letting it be known that as a council of social agencies it favored these things. Such action apparently 
was not attempted without previous study and interpretation. To achleve these varlous purposes the Council has relled more and more on research as the basis for 1ts work. The methods used by the council have been committee action and study, conferences, bulletins, statistical reporting and meetings.

Looking toward the future it seems possible that the work of the Health Counc1l and the council of Soclal Agencles may be combined, for the old line between the health and social aspects of community problems is growing increasingly $\mathrm{d} 1 \mathrm{~m}$. If the goal of coordinated social planning is to be carried out to the fullest extent it would seem to be advisable to bring about this merger. As the function of the Council has expanded the detailed work of the Executive has been greatly increased. It would seem advisable to work towards relleving her of some of the responsibility. The acquisition of a group woris consultant is certainly a step in this direction.

Since 1942, the war connected activities of the Councils have been centered in the Defense Welfare Services. Without the existing pattern of cooperation established by the twenty years of experience of the Council of Social Agencles there probably would have been greater difficulty in adjusting the agency programs to meeting increased 
wartime pressures. Actually, in the ultimate sense the war effects all activities of the Council, but the work which is not directly related to the war continues in order to maintain the standards of work established through the years. 
BIBLIOGRAPHY 


\section{BIBLIOGRA PHY}

Books

Atwater, Pierce. Problems of Administration in Social Work. Minneapolis: University of Minnesota Press, 1940.

Fink, Arthur E. The Fleld of Soclal Work. Wew York: Henry Holt \& CO., 1942:

\section{Reports}

Loosley, R. F. The Loulsville Survey, Summary Report. Louisvil10: Loulsvilie Communtty Chest, 1939.

Slingerland, W. H. Child Welfare Fork in Louisville. Loulavilie: The Welfare League, I919.

Whiting, Theodore E: and Wooften, T. J. Summary of Rellef and Federel Work Program Stat1stics, 1933-1940. Vashington: Government printing office, 194I.

\section{Articles}

Bue11, Bradley: "Council Leadership and Defense," Survey Mid-monthly, August, 1941, pp. 234-241.

Johnson, Arlien, "Local Soclal Planning," Survey Midmonthly, October, 1940, pp. 291-294.

\section{Pamphlete}

Liggett, David. Can Councils Click? New York: Community Chests and Councils, Inc., I94l.

Whet Councils of Soclal Agencies Do. New York: Community Chests and Councils, Inc., I939.

\section{Newspaper Cl1ppings}

Courler-Journal (Louisville), March 21, 1936; March 9, 1939. Herald Post (Louisville), March 23, 1929. 
Loulsville Times, March 25, October 3, 1936.

\section{Unpublished Materlals}

Bateman, Mildred D. "Lay-Participation in the Private Family Agency, Louisville, Kentucky." Unpublished Master's Thesis, Graduate Division of Social Administration, University of Loulsvilie, 1941.

Kavinoky, Edward H. "Presidential Address" at the Annual Meoting of the Niagara Falls Council of Soclal Agencles, Buffalo, New York, October 23, 1940.

Swander, T. L. "Effective Organization of Social Porces in Cities Under 500,000 Population." Paper read at the National Conference of Social Work, Atlantic City, June 3, 1941.

Wilson, Elizabeth A. "Recreation in Louisville." UnpubIfshed Master's Thesis, Department of Soclology, University of Loulsvilie, 1938.

Constitutions and By-Laws:

Pederation of Social Agencies, 1917. community Council, 1918.

Board of Workers of the Welfare League (no date). Case Work Divis1on, 1924.

Recreation Council, 1924, 1930.

Health Council (original one - no date), March, 1925. Commun1ty Chest, 1926, 1933, 1940.

Family and Child Welfare Council, 1925, 1930.

Council of Social Agencies, 1935, 1941.

Annual Reports :

Louisville Community Council, 1919, 1921.

Buffalo Council of Social Agencies, January, 1943.

Loulsville Council of Social Agencies, 1938, 1941, $1942,1943$.

Loulsville Family and Child Welfare Counc1l, 1927.

Loulsvilie Health Council, 1926, 1927.

Loulgvilie Welfare League, 1921.

Minutes :

Case Work Council, 1924-1925.

Community Chest -

Adv1 sory Committee, 1925-1926.

Executive Committee, 1928. 


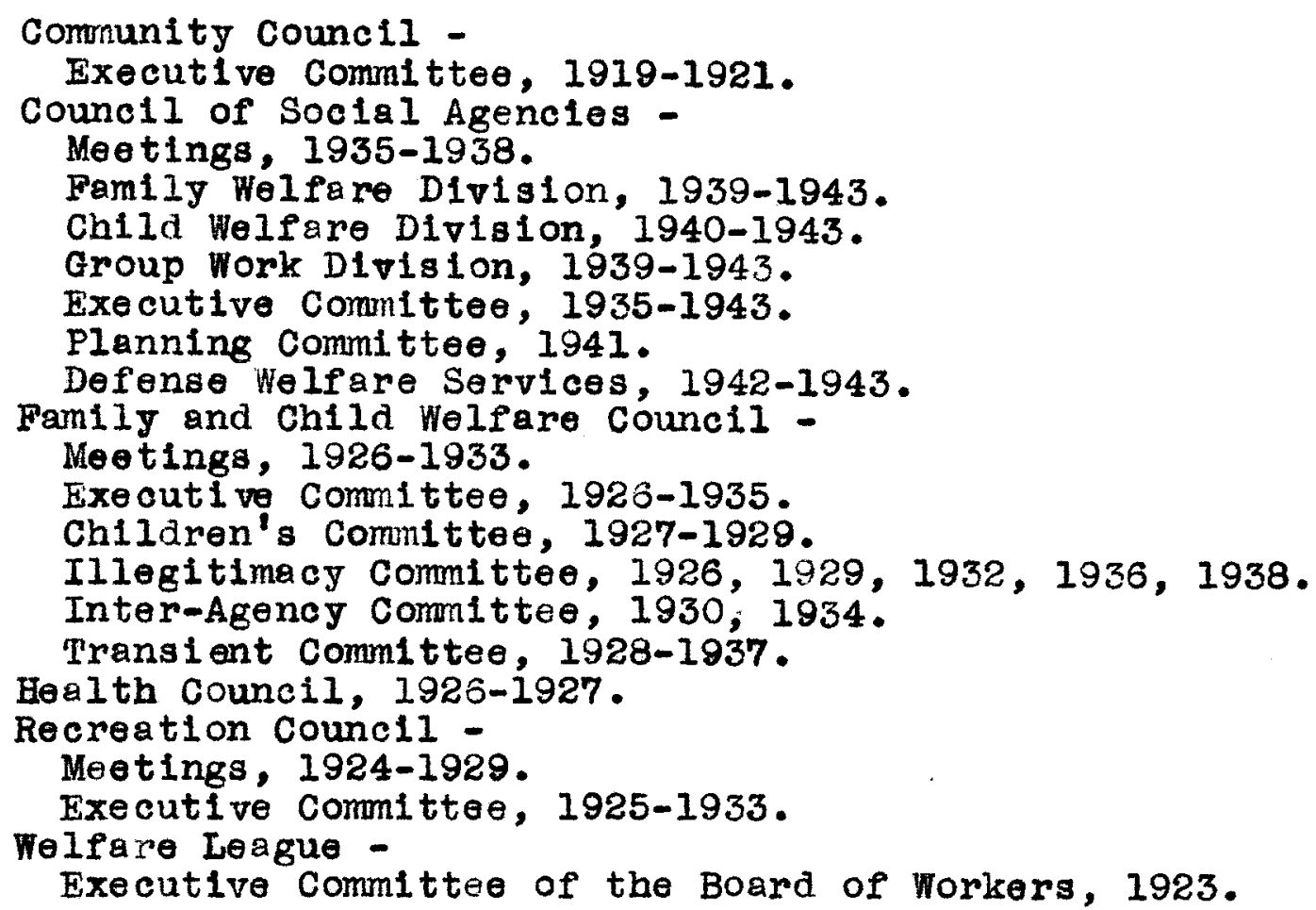

\section{Miscellaneous}

The Community. Louisville Pederation of Social Agencies, JuIy, 1913, September, 1919.

D1rectory of Community Chests and Councils, 1942. New York: Community Chests and Counclis, Inc., 1942.

The Kentucky Department of Welfare Bulletin. Vol. IV, Tharch and Apri, 1943), Frankfort: State Department of Welfare.

The Louisvilie Soclal Service Directory. Loulsville: Community counc11, I92I. 
AF PENDIX 
APPENDIX I

COMMUNITY CHEST OF LOUISVILLE AND JEFFERSON COUNTY, KENTUCKY BY-LAWS

(As amended Miarch 7, 1940)

ARTICLE I.

Name

Section 1. The name of this corporation shall be the community Chest of Loulsvilie and Jefferson County, Kentucky.

\section{ARTICLE II.}

Objects

Section 1. To promote and co-ordinate work of associations for clvic, educational and philanthropic purposes, to eliminate waste in effort and expenditure, and to apply to social conditions, scientific principles, plans and methods approved by study and experience.

Section 2. (a) To give financial assistance to associations for clvic, educational, or philanthroplc work. (b) To sollclt, collect, recelve, borrow, and hold money and property, both real and personal, by gift or devise; to convert property so recelved into cash, and to disburse funds held and ralsed by $1 t$, in accordance with the specified objects of this organization. 
ARTICLE III.

Membership

Section 1. The membership of the community Chest shall consist of two (2) representatives of each participating agency in the community chest, at least one of whom shall be a lay member of the Board of Directors of such agency; and a number of lay contributors equal to the number of such agencies. Such representatives and contributors shall be known as members.

Section 2. Each member shall be entitled to one vote at any meeting of the community chest.

Section 3. All agency representatives shall serve until and including the annual meeting of the community Chest following their election and until their successors have qualified. One month prior to the annual meeting, the organizations entitled to two (2) representatives shall be so notified and the term of such representatives shall begin immediately after sald meoting.

Section 4. Prior to the annual meeting, the President of the Community Chest shall appoint a Nominating Committeo of seven (7), three (3) of whom shall be selected from the agency representatives and four (4) from lay contributors to the Cormunity Chest. This committee shall be responsible for nominations for members to represent the contributors 
as outlined in Section 1 of this Article, and to nominate Directors as outlined in Article $V$, Section 2. This Nominating Committee shall report at the annual meeting of the Community chest.

\section{ARTICLE IV. Meetings}

Section 1. The membership shall meet twice a year, and the Board of Directors shall make a report at such meetings of 1 ts acts and proceedings. The annual meeting of the Community Chest shall be held in February of each year. Special sessions may be called at any time by the President or Vice-Presidents, and shall be called at the request of twenty (20) members of the Community Chest, or flve (5) members of the Board of Directors. Such requests shall specify the subject or subjects to be considered. Section 2. At any regular or special meeting of the community Chest a quorum shall consist of fourteen (14) members, provided at least seven (7) of them are representatives of at least seven (7) different participating agencies.

ARTICLE V. Board of Directors

Section 1. The management of the community Chest shall be 
vested in a Board of Directors consisting of twenty (20) members, $s 1 \times(6)$ of whom shall be elected each year to serve for three years or until their successors are elected; one of whom shall be appointed annualiy by the council of Social Agencies and one by the Health council.

Section 2. It shall be the duty of the Nominating Committeo mentioned in Article III, Section 4, to nominate one (1) candidate for each vacancy on the Board of Directors. Section 3. Any contributor to the Community Chest shall be eligible for election as a Director.

Section 4. The report of the Nominating Committee shall be submitted in writing at the annual meeting. Additional nominations may be made from the floor.

Section 5. The Board of Directors shall meet monthly except in July and August, and at such other times as meetings may be called.

Section 6. At any regular or special meeting of the Board of Directors, seven (7) members shall constitute a quorum.

\section{ARTICLE VI. Officers}

Section 1. The Board of Directors immediately after the annual meeting shall elect the following officers of the Community Chest: a President, who shall preside at meetings 
of the Bogrd of D1rectors, one or more Vice-Presidents, a Treasurer, a Secretary, an Assistant Treasurer, an Assistant Secretary, and an Auditor. The office of Secretary and Treasurer may be held by the same person. The officers shall hold offlce for one year, or until the1r successors are elected and qualify, and shall be eligible for reelection.

Section 2. Vacancies in the membership of the Board or in any of 1ts offlces shall be filled by the Board of Dlrectors to serve unt1l the time of the next annual meating. Section 3. The Board of Directors may employ an Executive Secretary who shall be responsible to the Board for the organization and supervision of a suitable staff. The Executive Secretary shall be responsible to the Board of Directors for the organization and co-ordination of a sultable staff for each the Council of Social Agencies and Health Council, to be selected with the approval of the Committee, however named, fulfiling the function of executive committee of such council.

Section 4. The Treasurer, Assistant Treasurer, Assistant Secretary, Auditor and Executive Secretary shal g give such bond with approved surety for the falthful performance of their duties and in such amount as shall be fixed by the Board of Directors. 
ARTICLE VII.

Standing Comittees

Section 1. The President shall appoint annually from the contributors, subject to the approval of the Board of Directors, a Campaign Committee. This committee shall be responsible for securing funds required by the Community Chest.

Section 2. The President shall appoint annually from the contributors, subject to the approval of the Board of Directors, a bunget Committee of fifteen (15) members which shall have charge of the budgetary functions of the Community chest, subject to the approval of the Board of Directors.

Section 3. The President shall appoint annually from the contributors a Finance Committee of not less than three (3) nor more than five (5) members, subject to the approval of the Board of Directors. If possible, the Chaiman of the Budget Comittee and the Treasurer shall be made members of this committee. The Finance committee shall pass upon the monthly appropriations to financially participating agencies, and shall have immediate supervision of the financial concerns of the Community Chest, and shall perform such other duties consistent with these by-laws as may be from time to time assigned to 1t by the Board of Directors. 
Section 4. The planning function of the Community chest shall be discharged by the Councli of Soclal Agencles and the Health Council, which will represent all agencles as far as posible, public and private, within their respective flelds. Such counclis may draw up their own rules and regulations, subject to the approval of the Board of Directors and conforming to the by-laws of the Community chest. They shall also provide for the election of their own officers. The duties of these counclis shall be to initlate and supervise all business relating to relationships between organizations, standerds of work, to advise upon the requests of the Budget Committee regarding matters of social importance and to take such measures as ma seem desirable to Improve the social and health work of the community, reporting to the Board of Directors on matters of mutual concern. Section 5. Other special committees may be appointed by the President as ordered by the Board of Directors. The President and Executive secretary shall be ex-officio members of all committees.

ARTICLE VIII.

\section{Budgets}

Section 1. All agencies particlpating financially in the Community Chest must submit to the Budget Committee such financial and statistical reports as may be required. 
Section 2. The Board of Directors shall have final authority to determine the final allocation of funds from the community Chest to participating agencies, and for the provision of funds for the maintenance of the community Chest office and those of 1ts standing committees.

\section{ARTICLE IX.}

Financial Participation in the Comunity Chest

Section 1. To be aligible for financial participation in the Community Chest, an organization must meet the following requirements :

A. Have a responsible Board or Directors and (a) In the case of National Organizations have a competent Advisory Board of local persons and (b) in the case of local organizations be incorporated in Kentucky.

B. Have accounts audited annually by an accountant satisfactory to the Budget Committee.

C. Keep adequate statistical records as requested.

D. Meet some real need of the community which is not already met by an existing agency or which cannot loglcally be assumed as the responsiblilty of an existing agency.

D. Use standard methods of social work, cooperating with other agencies in proventing duplication of effort and promoting economy and efficiency. 
F. All records both social and financlal shall always be open to an accredited representative of the community chest. The system of bookkeeping maintained by member agencies shall be approved by the community chest.

G. On becoming a financial participant in the Community chest, the ageney must submit a complete list of contributors and amounts contributed the previous year and current year to date.

B. The Board and staff 111 be expected to cocperate actively in the financial campaign.

I. Use the Social Service Exchange, if required.

J. Shall not inaugurate or undertake any new activity requiring the expenditure of funds without the approval of the Bosrd of D1rectors of the community Chest.

Section 2. Organizations meeting the foregoing requirements may upon application be admitted to financial participation by the Board of Directors in its discretion. Section 3. There shall be no interference with the internal management or with the traditions of any financially participat ing agency.

ARTICLE $X$.

Separate Solicitation by Particlpating Agencies

Organizations particlpating financially shall not solicit or collect funds from the general public in any 
manner or for any purpose whatsoever, unless express permission of the Board of Directors of the Community Chest is given.

\section{ARTICLE XI.}

\section{Dongtions}

Section 1. Organizations participating financially may recelve gifts, bequests and devises. Direct gifts applicable to current needs must be reported in the monthly financial statement to the community chest and uniess specifically designated for special purposes by the donors may be deducted from the amount required of the community Chest.

Section 2. Endownents, real estate, personal property, trust or permanent funds shell remein the property of beneflclaries; and the beneflclaries may add to them by gifts, bequests and devises specified for such purposes; provided, however, that the income from such funds shall be applied to current expenses and deducted from the amount required of the community Chest, unless specifically designated for special purposes by the donors.

ARTICLE XII.

Designations by Contributors

Subscribers to the community chest shall be supplied 
with subscription forms together with a list of the names of the member agencies. Contributors may either designate their gifts for specific purposes, or may leave distribution to the Board of Directors. The Community Chest shall send to each agency, as soon as possible after the annual campaign, a list of such designated contributions. Any surplus of designations over the amount actually budgeted to any organization shall be credited to its future budgets.

ARTICLE XIII.

Title to Property

Title to the property of the Community Chest shall be held in the name of the corporation.

ARTICLE XIV.

\section{Llability of Members}

The property of its members shall not be liable for the debts of the Community Chest.

ARTICLE XV.

Audit

The accounts of the community chest shall be audited annually by an independent qualified accountant. 
ARTICIE XVI.

Wthdrawal and Expulsion

Section 1. Any financially participating agency may withdraw from the community chest at any time. The agency withdramIng shall be entitled to recelve from the community chest any amount designated to it and paid by contributors in excess of what it already has recelved on account from the Community chest, provided it shall in no event recelve more than the budget it would have received at the end of the year.

Section 2. If any financially participating agency shall refuse or neglect to comply with the regulations now or which hereafter may be prescribed by the community chest, then such agency shall be subject to expulsion from participation in the community chest, provided that charges shall be presented at a meeting of the membership and notice there of shall be sent to the offending organization. An affirmative vote of the majority of the members must sustain the motion for expulsion. This vote shall be taken by secret ballot.

ARTICLE XVII.

\section{Amendment}

The se by-laws may be altered, repealed or amended by 
a majority vote of those present at any regular or special meeting of the membership, after written notive with a copy of proposed amendment has been malled to the members five (5) days before the meeting. 


\section{ARTICLES OF AGREEMENT}

\section{ARTICLE I - NAME}

The name of this Council shall be the Council of Social Agencies of Loulsville and Jefferson County.

\section{ARTICLE II - PURPOSE}

Section 1. The purposes of the Councll of Soclal Agencies Bre:

a. To aid in community social planning by coordinating the services of the existing agencies and by gathering factual material wich will reveal needs and lead to the creation of new programs which w11l help to meet these noeds.

b. To carry on a program of education for the citizens of the community recognizing the need for social services and the standards which must be maintained if these services are to be performed effectively.

c. To engage in direct social action where such action is deemed necessary to effect desireble chenge in community iffe.

d. To administer certain services thet can be provided most advantageously by a central body.

\section{ARTICLE III - MEMBERSHIP}

Section 1. Any social agency, public or private, or other organized group interested in furthering the purposes of this council may be granted membership in the Council of Social Agencies on the approval of the Executive Committee.

Section 2. From time to time this council may elect to 1ts membership, for the current year, interested individuals not to exceed the number of member agencies or groups which form the membership of this Counc1l. 
Section 3. Members of all comrittees shell become members of the council.

\section{ARTICLE IV - DELEGATES}

Section 1. Each member organlzation of the Council shell be represented by two delegetes, who shall, when practical, be a board momber and a staff member in the case of the privete agencles, and an interested citizen and a staff member in the case of public agencies.

Section 2. The term of office of these delegates shall be one jear and the methods of their gelection shall be determined by each agency, provided that no delegate shall represent more than one agency. Each agency may appoint one alternate for each of its delegates.

\section{ARTICLE V - VOTES}

Section 1. Each delegate or Individual member shall have one vote upon any motion before the Council.

\section{ARTICIE VI - OFFICERS}

Section 1. The officers of the Council of Social Agencies shaII be Chairman, First Vice Chairman, Second Vice Chairman, Third Vice Chairman, and Fourth Vice Chalman and Executive Secretary.

Section 2. The Chairman and First Vice Chaiman shall be Olected annually by the council from its membership. The Chal man shali be the representative of the council on the Executive committee of the community Chest. The Chairmen of the Family Welfare, Child Welfare and Group Work Divisions shall serve respectively ex-officio as Second, Third and Fourth vice Chaimen of the Council. The Executive Secretary shall be appointed in accordance with Article VI, Section 3 of the By-Laws of the Community Chest of Louisville and Jefferson County, as amended March 7, 1940.

\section{$\triangle$ RTICLE VII - EXECUTIVF COMMITTEE}

Section 1. There shall be an Executive Committee consisting of the officers of the counc11; six members elected by the Council, two being elected at each annual meeting for three 
year terms; one member from each Division elected by each Division before the annual meeting; the chaimen of the Advisory Committees for the Volunteers' Bureau and the Social Service Exchange; nd six members appointed by the Chairman of the council, two being appointed each year for three year terms. (Total 22)

Section 2. Members shall be appointed by the Chaiman of the Councli to f1ll all vacancies in the Executive Committee until the next regular election, with the exception of the Chalmen of the Volunteerg' Bureau and the Soclal Service Exchange, which shall appoint their own.

Section 3. The Executive Committee shall have the power to perform aIl the functions of the council between meetings of the carneil.

Section 4. The Executive Secretary of the Community Chest shaI be an ex-offlc10 member of the Executive Committee of the counc1l.

Section 5. The Executive Committeo shall each year prepere for the council a budget to be presented to the community Chest and shall approve the budgets of the Volunteers' Bureau and the Social Service Exchange.

\section{ARTICLE VIII - COUNCII COMAITEEES}

Section 1. The chairman of the council upon consultation Fith the Executive Committee or upon action of the council may appoint such standing committees or special committees as may be deemed necessary at any time.

Section 2. There shall be a standing Advisory Committee on the volunteers' Bureau, at least four of whom shall be appointed by the Chairman of the Council, two appointed each year for two year terms; other members to be named by the Advisory Committee. The Chaiman of the Advisory Committee shall be elected from among the members, and shall serve ex-officio as a member of the Executive Comittee of the Council. The main function of the Advisory Committee shall be that of a supervisory and policy making committee. It shall be the duty of this committee to recommend annually a budget for the volunteers' Bureau to the Executive Committee of the Councll of Soclal Agencles. The staff of the Voluntears' Bureau shall be appointed in accordance with Article VI, Section 3 of the By-Laws of the Community chest of Loulavilie and Jefferson County, as amended March 7, 1940. 
Section 3. There shall be a standing Advisory Committee on the Social Service Exchange, at least four of whom shall be appointed by the Chairman of the Council, two appointed each year for two year terms; other members to be named by the Advisory Committes. The Chairman of the Advisory Comlttee shall be elected from among the members, and shall serve ex-officio as a member of the Executive Committee of the Council. The main function of the Advisory Comittes shall be thet of a supervisory and pollcy making committeo. It shall be the duty of this committee to recommend annualiy a budget for the Social Service Exchange to the Executive Committee of the Council of Social Agencies. The staff of the Social Service Exchange shall be appointed in accordance with Article VI, Section 3 of the By-Laws of the Community Chest of Loulsville and Jefferson County, as amended March 7, 1940 .

\section{ARTICLE IX - MEETINGS}

Section 1. There shall be three meetings of the council annuaIIy, in the fall, winter and spring. The election of officers shall be held at the spring meeting. Other meetings shall be held at such time or place as the Executive committee may determine or upon written request of fifteen members of the council.

Section 2. The Executive complttee shall meet upon the call of the chairman of the council but not less than three times a year.

\section{ARTICLE X - QUORUM}

Section 1. One-fifth of the active members shall constitute a quorum of the council. Nine (9) members shall constitute a quorum of the Executive Committee.

\section{ARTICLE XI - DIVISIONS}

Section 1. The Cauncil shall be organized into three diviBions, a Family Welfare Division, a Child Welfare Division, and a Group Work Division. Each agency in the Council shall decide to which Division it wishes to belong, and may be a memper of more than one Division. The Councit delegates of 
to which the agency belongs. Interested individuals may be made members of a Division not to exceed the number of agencies in the Division.

Section 2. Within each Division there shal? be a Planning Committer consisting of elght members chosen as follows: three being elected annualiy two weeks before the spring meeting of the Council for two year terms, and two being appointed annualiy by the Chairman of the Council of Social Agencies. In making these appointments the Chalman shall make certain that both public and private agencies are repregented. Each Planning Committe shall serve the Division as a program and activities body and in a general capacity within the Division.

Section 3. Each Planning Committeo shall choose a chalman from Its own members two weeks before the spring meeting of the Council of Social Agencles. The chalman shall be a layman, whenever possible, and shall also serve as Chairman of the Division and on the Executive Committee of the Council.

Section 4. Each Planning Committee shall choose one of its own members to serve as Secretary, both of the Committee and of the Division.

Section 5. The Executive Secretary of the Councll shall be ex-offic10 a member of each Planning committee, without vote.

Section 6. The Chairman of the Division, upon cansultation With the Planning Comittee or upon action of the Division, may appoint such standing cominitees or special committees as may be deemed necessary at any time.

\section{ARTICLE XII - AMENDMENTS}

Section 1. These Articles of Agrement may he amended by a majority vote of members present at any meeting, provided that the proposed amendment shall have been submitted in writing to each member at lesst seven days before action is taken, and thet the amendments do not conflict with the By-Laws of the Community Chest.

Revised: November 6, 1941. 


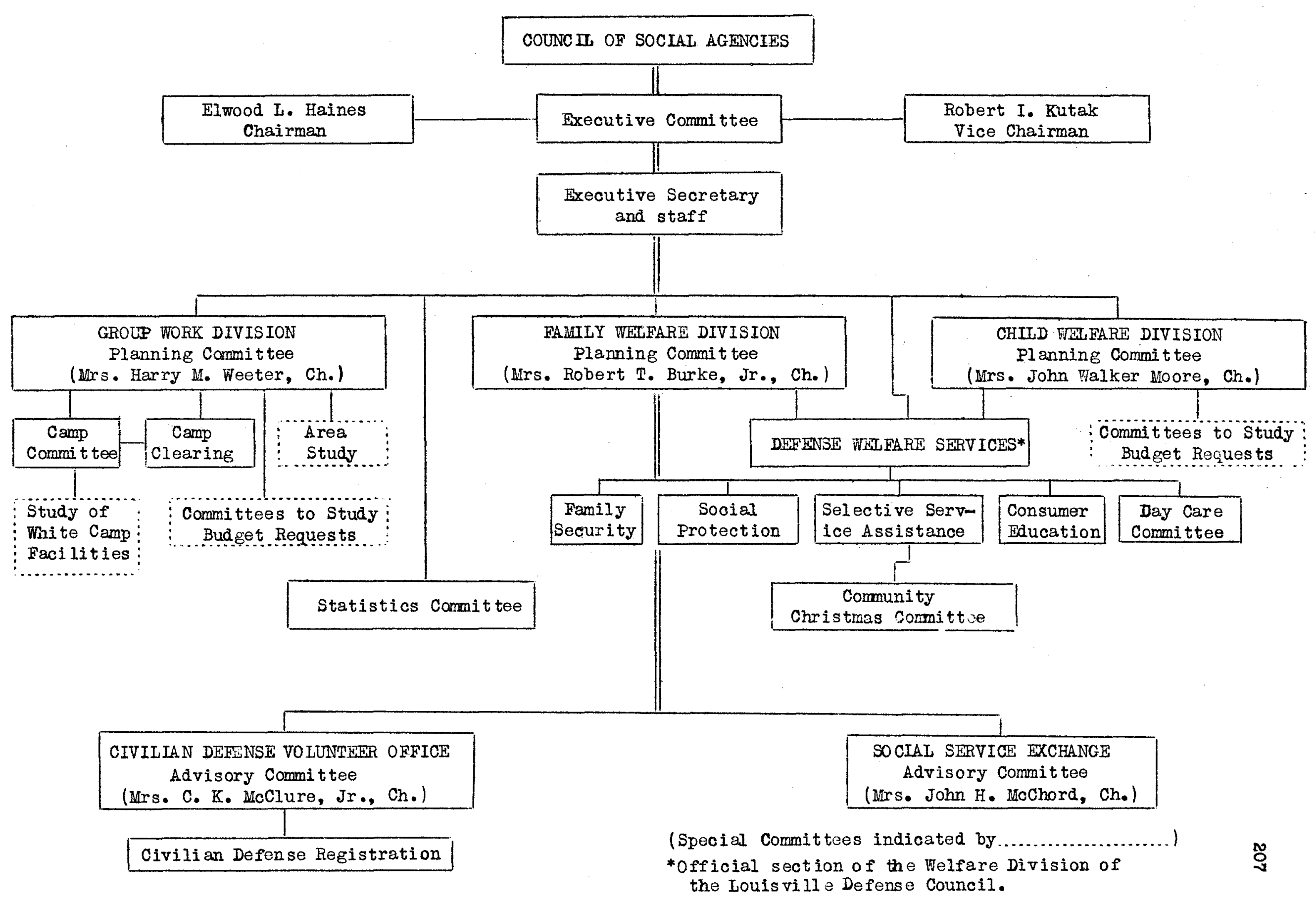




\section{Family Helfare}

Aid to Dependent Children Dept. -American Red Cross

*Bd. of 0ld Age and Survivors Ins. Churchwomen's Federation Committee of Fifteen (Ministerial)

* Consumers League of Kentucky Dept. of Admissions - General Hosp. Dept. of Wel fare

* Family Service Organization

*-Grad. School of Soc. Adm. U. of L.

* Home for Incurables

Hope Rescue Mission

*Hospital Social Service

Jefferson County Welfare Dept.

* Jewish Welfare Federation

Ky. State Imployment Service

* Legal Aid Society

Lou. Council of Churches

Lou. Goodwill Industries

-Lou. Urban League

* Men tal Hygi one Cl inic

* Municipal Bur aau of Soci al Service -Municipal Housing Commission

01d Ago Assis tance Division

St. Vincent de Paul Society

-Salvation A rmy

Salvation Army Mon's Service Conter

Social Hygi ono Assn. of $\mathrm{Ky}$.

* Travelors Aid Socicty

Visiting Nurso Association

W.P.A. Division of Employment

Total $\underline{82}$ organizations.

\section{Child Welfare}

American Legion - Child Welfare Com. Child Housing Division

*Children's Agency

Christian Church Orphans' Home Coll ege Club

Colored Orphans' Home Soci ety

East Find Day Nursery

Fone of the Innocents

Junior League of Louisvilie

Juvenile Court

Kentucky Children's Homo

Ky. Crippled Children's Com.

Ky. Society for Crippled Chil.

League of Catholic P.T.A.

League of Women Voters

Lou. Baptist Orphans' Home

Lou. Counci l - P.T.A.

Lou. \& Jeff. Co. Ch. Home

Our Lady's Home for Infants

Presbyterian Orphans ' Home

St. Jos cph Orphans' Homo

St. Thomas Or phans' Home

St. Vincent Or phans' Home

Sisters of the Good Shepherd

St. Child Jolfare Div. (colored)

Susan Spe dav is Home

Synod. Prosby. Orphans' Homo

Union Go spel Mission

Visiting Toacher Dopt.

Younger Tomen's Club

Agencies $r$ eprosented in more than on Division aro designated as follows:
Group Work

Baptist Fellowship Center Boy scouts of America. Boy Scouts - Colored Division Cabbage Patch Settlement

* \#Chris t Church Cathedral Division of Recreation Girl Scouts

*Iou. Free Fubl ic Library

Lou. Fresh Air Home

National Youth Administration Neighborhood House Plymouth Settlement House Fresby. Color ed lli ssion Rose Fudson Community Center Unitod Ssrvice Or ganizations Wesley Community House

Vi.F.A. Recreation Pro ject

Y. Mi. C. A.

Y. H. H. A.

Y. W. C. A.

Y.I.C . - Phyllis Whoatley Br.
* Also Child Velfare

* Also Family Welfaro

- Also Group Work 
THE COMMUNITY SOCIAI PLANNING COMMISSION AND THE COUNCII OF SOCIAL AGENCIES

\section{THE COUNCIL OF SOCIAI AGENCIES}

Alds in community social planning by co-ordinating services of existing agencies and gathering factual material which will reveal needs and lead to creation of new programs.

Carries on program of education in need for social servi $\infty$ and standards which must be maintained.

Engages in direct social action where such is deemed necessary to effect desirable changes.

Membership composed of representatives of both public and private agencles.

\section{THE COMMUNITY SOCIAL PLANNING COMMISSION}

The Councils feels that direct social action, where action is deemed necessary to effect desirable changes in community life, can best be effected through an official group representative of the entire citizenry. It feels that it is carrying out its purpose on this point in offering this recommendation that the commission be created.

The Commission would be the offlcial "executive committee" on social planning and execution, to which would be referced all questions, studies and recommendations in this field for possible action.

By virtue of its officlal appointment, it would have official stand ing and authority and would be familiar with the problems and programs of the city and county administration as they a re related to such questions as recreation, juvenile delinquency, child care, housing and health. It would be recognized as the means of co-ordinating all community forces.

The Comision would see the whole picture and would request various agencles, public and private, as it seemed wise, to under-take activities which would contribute towards community bettement in the light of changing conditions and needs. 
Because of its ofilcial status, it would be in the best position to secure adequate publicity, thus developing a greater social consclousness, and increased general support for neoded profects in the social welfare field.

It would have the task of long-time planning and the charting of objectives towards which the community should work in the next five or ten years. Post-war planning for our community should begin now.

This small group would be in a sense a Board of Directorg in the field of social welfare. It would have the authority to call in experts for consultation and would operate through a number of working committees which would bring in reports for the Commission's consideration. It would hav $\theta$ the right to review freely everything in the community which would have bearing upon any particular problem.

The Commission should be without political ties or commitments and its recommendations would be made at any time to the administration or to any agencies in the communit $\mathrm{y}$.

\section{RELATIONSHIP OP THE PLANNING COMMISSION AND THE COUNCIL OF SOCIAL AGENCIES}

The Council of Soclal Agencies, through its representation on the commission, rould be familiar with the procedure and would expect to be used by the commission for research work. Furthermore, the council, being in an excellent position to feel the pulse of the community and to know what is golng on within the agencles, would be free at all tines to present its own original findings and recommendations to the commission for consideration.

The Council does not feel that the proposal that this commission be created is an admission of 1 ts own fallure or in any sense an abrogation of its powers. It rather feels that a more united attack on our social problems is needed and in proposing this method, the council is Iiving up to the purpose for which it was created.

It is suggested that the Commission meet with an equal number of representatives from the council of Social Agencies as soon as possible to define further the interrelationships and to make sure that there is no misunderstanding regarding the part that the Council will play as the chief assistant to the commission. 